EGG-WTO--10244-Vol.1-Vol.2

DE92 019612

\title{
Mixed and Low-Level Waste Treatment Facility Project
}

\author{
Executive Summary
}

\author{
Volume 1 \\ Program Summary Information
}

\author{
Volume 2 \\ Waste Stream Technical Summary
}

(Draft)

\begin{abstract}
Published April 1992
Idaho National Engineering Laboratory

EG\&G Idaho, Inc.

Idaho Falls, Idaho 83415
\end{abstract}




\section{MIXED AND LOW-LEVEL WASTE TREATMENT FACILITY PROJECT}

\section{EXECUTIVE SUMMARY}

Mixed and low-level wastes generated at the Idaho National Engineering Laboratory (INEL) are required to be managed according to applicable State and Federal regulations, and Department of Energy Orders that provide for the protection of human health and the environment. The Mixed and Low-Level Waste Treatment Facility Project was chartered in 1991, by the Department of Energy to provide treatment capability for these mixed and low-level waste streams. The first project task consisted of conducting engineering studies to identify the waste streams, their potential treatment strategies, and the requirements that would be imposed on the waste streams and the facilities used to process them. This report documents those studies so the project can continue with an evaluation of programmatic options, system tradeoff studies, and the conceptual design phase of the project.

Presently, the Waste Experimental Reduction Facility and the Idaho Chemical Processing Plant perform the majority of the mixed and low-level waste treatment at the INEL. The Idaho Chemical Processing Plant treats aqueous liquid waste streams and will continue to process these wastes in the future. The Waste Experimental Reduction Facility treats $67 \%$ of the solid low-level waste volume generated at the INEL, and has limited incineration capabilities for mixed waste. Most mixed waste streams are being stored at various locations at the INEL until treatment capability becomes available. A lack of appropriate treatment capability, and projected closure for existing treatment facilities, requires the development of additional treatment capability for the mixed and low-level wastes being generated. One programmatic option to be considered is the construction of a Department of Energy-owned Mixed and Low-Level Waste Treatment Facility located at the INEL.

The engineering studies, initiated in July 1991, identified 37 mixed waste streams, and 55 lowlevel waste streams. This report documents the waste stream information and potential treatment strategies, as well as the regulatory requirements for the Department of Energy-owned treatment facility option. This report comprises three volumes and two appendices organized as follows. 
Volume 1, Program Summary Information, explains the overall program mission, the guiding assumptions for the engineering studies, and summarizes the waste stream and regulatory information.

Volume 2, Waste Stream Technical Summary, encompasses the studies conducted to identify the INEL's waste streams and their potential treatment strategies. It explains the rationale and approach used to conduct the studies, and summarizes the waste stream characterization data and potential treatment strategies documented in the engineering design files contained in Appendix B.

Volume 3, Waste Treatment Technologies, describes the technologies referenced in the waste stream treatment strategies. Each technology proposed for a waste stream refers to this volume, where the technology's application, underlying principles of operation, advantages, disadvantages, and technology status are described.

Appendix A, Environmental \& Regulatory Planning \& Docisnentution, identifies the regulatory requirements that would be imposed on the operation or construction of a facility designed to process the INEL's waste streams. These requirements are contained in five reports that discuss the following topics: (1) an environmental compliance plan and schedule, (2) National Environmental Policy Act requirements, (3) preliminary siting requirements, (4) regulatory justification for the project, and (5) health and safety criteria.

Appendix B, Waste Stream Engineering Files, comprise the engineering design files for this project study. The engineering design files document each waste stream, its characteristics, and identified treatment strategies. 


\title{
Mixed and Low-Level Waste Treatment Facility Project
}

\author{
Volume 1 \\ Program Summary Information
}

(Draft)

Published April 1992

Idaho National Engineering Laboratory

EG\&G Idaho, Inc. Idaho Falls, Idaho 83415 


\section{CONTENTS}

ACRONYMS $\ldots \ldots \ldots \ldots \ldots \ldots \ldots \ldots \ldots \ldots \ldots \ldots \ldots \ldots \ldots \ldots \ldots \ldots$

1. INTRODUCTION $\ldots \ldots \ldots \ldots \ldots \ldots \ldots \ldots \ldots \ldots \ldots \ldots \ldots \ldots \ldots \ldots \ldots$

2. PROGRAM MISSION $\ldots \ldots \ldots \ldots \ldots \ldots \ldots \ldots \ldots \ldots \ldots \ldots \ldots \ldots$

3. BACKGROUND $\ldots \ldots \ldots \ldots \ldots \ldots \ldots \ldots \ldots \ldots \ldots \ldots \ldots \ldots \ldots \ldots$

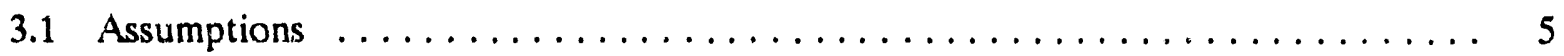

Waste Assumptions $\ldots \ldots \ldots \ldots \ldots \ldots \ldots \ldots \ldots \ldots \ldots \ldots$

3.1.2 Treatment Facility Assumptions $\ldots \ldots \ldots \ldots \ldots \ldots \ldots \ldots \ldots \ldots$

3.1.3 Other INEL Facility Assumptions $\ldots \ldots \ldots \ldots \ldots \ldots \ldots \ldots$

3.1.4 Regulatory Assumptions $\ldots \ldots \ldots \ldots \ldots \ldots \ldots \ldots \ldots \ldots \ldots$

4. WASTE STREAM STUDIES OVERVIEW $\ldots \ldots \ldots \ldots \ldots \ldots \ldots \ldots \ldots$

4.1 Identification of Waste Streams $\ldots \ldots \ldots \ldots \ldots \ldots \ldots \ldots \ldots \ldots \ldots$

4.2 Characterization of Waste Streams $\ldots \ldots \ldots \ldots \ldots \ldots \ldots \ldots \ldots \ldots$

4.3 Treatment Strategies $\ldots \ldots \ldots \ldots \ldots \ldots \ldots \ldots \ldots \ldots \ldots \ldots \ldots$

5. ENVIRONMENTAL REGULATORY REQUIREMENTS OVERVIEW . . . . . . 9

6. NATIONAL ENVIRONMENTAL POLICY ACT OVERVIEW $\ldots \ldots \ldots \ldots \ldots$

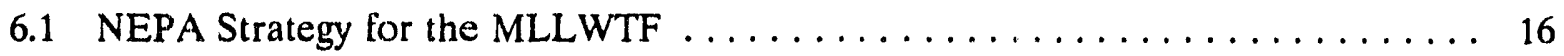

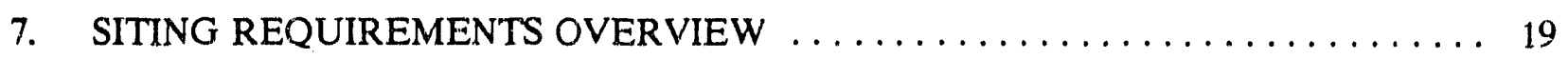

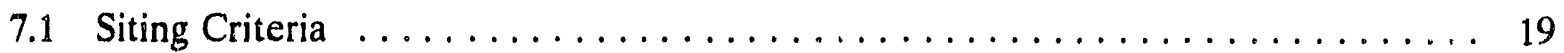

8. HEALTH AND SAFETY CRITERIA OVERVIEW $\ldots \ldots \ldots \ldots \ldots \ldots \ldots \ldots$

FIGURES

1. Compliance scheduie $\ldots \ldots \ldots \ldots \ldots \ldots \ldots \ldots \ldots \ldots \ldots \ldots \ldots \ldots \ldots$

2. MLLWTF schedule and NEPA compliance options $\ldots \ldots \ldots \ldots \ldots \ldots \ldots \ldots$ 


\section{TABLES}

1. Proposed federal regulations which may impact the mixed and low-level waste treatment facility $\ldots \ldots \ldots \ldots \ldots \ldots \ldots \ldots \ldots \ldots \ldots \ldots \ldots \ldots \ldots$

2. Attachment $1-$ INEL MLLWTF permitting and approval summary $\ldots \ldots \ldots \ldots$ 


\section{ACRONYMS}

AEA

ANL-W

BDAT

BRC

CEO

CEQ

CFR

DOE

DOE-ID

EDF

EIS

EO

EPA

ER

ERD

FR

FY

HSWA

ICPP

INEL

LDR

MLLWTF
Atomic Energy Act

Argonne National Laboratory-West

best demonstrated available technology

below regulatory concern

Contractor, Environmental Organization

Council on Environmental Quality

Code of Federal Regulations

Department of Energy

Department of Energy Idaho Field Office

Engineering Design File

Environmental Impact Statement

Executive Order

Environmental Protection Agency

environmental restoration

Environmental Restoration Department

Federal Register

fiscal year

Hazardous and Solid Waste Amendmen's

Idaho Chemical Processing Plant

Idaho National Engineering Laboratory

Land Disposal Restriction

Mixed and Low-Level Waste Treatment Facility 
MLLWDF

MWSF

NEPA

NOI

NRC

NRF

ORNL

PCB

PREPP

RCRA

ROM

RWMC

RWMIS

SD

TAN

TRU

TSA

TSD

WAC

WERF

WM

WMIS
Mixed and Low-Level Waste Disposal Facility

Mixed Waste Storage Facility

National Environmental Policy Act

Notice of Intent

Nuclear Regulatory Commission

Naval Reactor Facility

Oak Ridge National Laboratory

polychlorinated biphenyl

Process Experimental Pilot Plant

Resource Conservation and Recovery Act

rough order of magnitude

Radioactive Waste Management Complex

Radioactive Waste Management Information System

Supplemental Directive

Test Area North

transuranic

Transuranic Storage Area

treatment, storage, and disposal

waste acceptance criteria

Waste Experimental Reduction Facility

Waste Managemerit

Waste Management Information System 


\title{
Mixed and Low-Level Waste Treatment Facility Project
}

\author{
Volume 1 \\ Program Summary Information
}

\section{INTRODUCTION}

The intent of the Mixed and Low-Level Waste Treatment Facility (MLLWTF) project is to provide appropriate treatment capability for mixed and low-level waste streams generated at the Idaho National Engineering Laboratory (INEL). In order to accomplish this objective, a work scope was negotiated between EG\&G Idaho and the Department of Energy (DOE), which originated with Activity Data Sheet 5-E2 in fiscal year 1991 (FY-91). This report is the outcome of the preengineering studies performed for the MLLWTF project and will be used in the decision-making process regarding processing of mixed and low-level wastes generated at the INEL to assist with system tradeoff studies and the conceptual design phase of the project.

This report identifies mixed and low-level waste streams generated by INEL operations and selected environmental restoration (ER) activities, their potential treatment strategies, and the requirements that would be imposed on these waste streams and the facility(s) used to process them. Note that some information in this report, specifically environmental and siting requirements, is based on the assumption that the MLLWTF will be a DOE-owned facility located at the INEL.

The report is organized intc three volumes and two appendices containing specific areas of project information. Volume 1, Program Summary Information, explains the overall mission of the program, the guiding assumptions used to conduct the pre-engineering studies, and summarizes waste stream and regulatory information provided in subsequent volumes. Volume 2, Waste Stream Technical Summary, summarizes the waste stream studies that were conducted, specifically addressing the INEL waste streams identified, their potential treatment strategies, and global observations. Volume 3, Waste Treatment Technologies, provides a description of technologies considered during the identification of waste stream treatment strategies, addressing application, principles of operation, advantages, disadvantages, and current status. Appendix A. Environmental and Regulatory Planning and Documentation, contains: (1) an environmental compliance plan, (2) siting requirements, (3) NEPA requirements, (4) regulatory justification for the project, and (5) Health and Safety criteria. Appendix B, Waste Stream Engineering Files, is a compilation of all of the engineering files documenting each low-level and mixed waste stream investigated for this project. 


\section{PROGRAM MISSION}

The DOE generates significant amounts of mixed and low-level waste at the INEL resulting from energy- and defense-related projects. DOE's current philosophy focuses on bringing their operations into compliance with environmental laws and regulations and on developing the support structures necessary to manage their waste. To support this, programs are aimed at minimizing the amount of waste generated and at treating wastes which will continue to be generated. Although waste minimization measures will continue to cause a reduction in volumes of wastes generated, operations at the INEL will continue to generate mixed and low-level wastes. The waste feed streams identified for this program will include waste that is being generated from several sources within the INEL, including: (1) operating facilities, (2) decommissioning and decontamination of facilities, and (3) environmental restoration activities. The purpose of this program is to provide appropriate treatment capability for INEL waste streams.

An evaluation of treatment alternatives is being conducted to identify options and the impacts of implementing each of these options. The alternatives are intended to form a relatively complete set of reasonable, upper-level options for treating waste. The alternatives being evaluated will include as a minimum: no action, construct and operate a MLLWTF at the INEL, modify and operate the Waste Experimental Reduction Facility (WERF), modify and operate the Process Experimental Pilot Plant (PREPP), generator treatment, offsite treatment, and combinations of these alternatives. As a result of this study, management will be able to determine a course of action regarding mixed and low-level waste treatment for INEL waste streams.

One option being considered is the development of a DOE-owned facility at the INEL, (e.g., the MLLWTF), to treat mixed and low-level wastes. This MLLWTF will be a non-reactor nuclear facility used to treat, process, and package beta/gamma contaminated contact-handled and remote handled mixed and low-level wastes to render them acceptable for disposal. Processing and treatment at the MLLWTF will be done in accordance with the standards required by DOE, Environmental Protection Agency (EPA), and the State of Idaho. DOE's policy is to manage radioactive mixed waste according to the requirements of Subtitle $\mathrm{C}$ of the Resource Conservation and Recovery Act (RCRA), and the Atomic Energy Act (AEA), respectively. RCRA applies to the extent that it is not inconsistent with the AEA.

The scope of the MLLWTF project at the INEL is to:

- Protect human health and the environment

- Meet the waste acceptance criteria of the appropriate disposal facility

- Reduce the volume of waste

- Provide a stabilized waste form

- Treat mixed waste to satisfy EPA's treatment standards

while complying with Federal, State, DOE, and EG\&G Idaho requirements. 
The rationale for the treatment of mixed waste is based upon DOE's intent to progressively pursue treatment capability presently not in place. This is to avoid impacts from the violation of EPA and State of Idaho regulations and agreements. Treatment of the waste will be designed to produce a stabilized waste form which will significantly reduce environmental impacts, as well as render the waste acceptable for disposal at either the Radioactive Waste Management Complex (RWMC) or the proposed Mixed and Low-Level Waste Disposal Facility (MLLWDF), depending on waste type. 


\section{BACKGROUND}

At this time, $67 \%$ of the solid low-level waste generated at the INEL is sent to WERF for processing before final disposal at the RWMC. The remaining 33\%, representing greater than $99 \%$ of the radioactivity, is sent directly to the RWMC with no treatment prior to disposal. Mixed waste, waste containing both hazardous and radioactive components, is currently being stored until treatment becomes available for these waste streams. Storage locations at the INEL include, but are not limited to, the Mixed Waste Storage Facility (MWSF), the transuranic storage area (TSA) at the RWMC, and designated buildings at the Naval Reactor Facility (NRF), Test Area North (TAN), and the Argonne National Laboratory-West (ANL-W).

Support for the proposed design and construction of a mixed and low-level waste treatment facility is a result of the need for treatment of projected inventories of mixed and low-level waste streams generated at the INEL. In the case of low-level waste, treatment is used to maximize the longevity of existing and proposed disposal sites, as well as creating a more stable waste form. With the increasing pressures to reduce the volume of mixed and low-level waste for disposal, the ability to achieve a high degree of cost-effective volume reduction becomes a significant aspect of waste management. In the case of mixed waste, treatment will allow compliance with EPA regulations for the protection of human health and the environment. At this time, there is no disposal facility for mixed waste at the INEL, although INEL assumes that a permitted site for mixed waste disposal wili be available by the time the MLLWTF becomes operational. Without treatment and disposal alternatives for mixed waste, INEL has no capability to meet the land disposal restrictions and storage prohibitions established by RCRA.

Analysis of EPA and DOE requirements for managing mixed waste clarifies the conclusion that current mixed waste treatment capability and capacity at the INEL are inadequate to meet these requirements. Hazardous waste treatment technologies were developed for typical industrial wastes, which were the type evaluated by EPA in developing treatment standards. DOE mixed wastes are different from the typical industrial wastes evaluated because of their radioactive component; consequently, they may not be amenable to the treatment standards set by the EPA. Treatments need to be identified that will destroy or fix the hazardous components of DOE mixed wastes to meet EPA standards. Although identifying treatment technologies is important, it is not enough to avoid noncompliance with EPA regulations. These treatment technologies must be installed and implemented with sufficient capacity to handle projected volumes of waste generated at the INEL.

DOE-ID and EG\&G Idaho management are fully committed to the implementation of a comprehensive DOE-ID pollution prevention program (DOE/ID-10345). This commitment is demonstrated by the dedication of resources to the development and implementation of waste minimization goals and plans for all operations. For the purposes of this report, we have assumed that the volumes and types of mixed and low-level waste currently being generated will continue to be generated in the future. The influence of waste minimization on these waste streams has yet to be evaluated. Prior to Title I design of the facility, current mixed and low-level waste stream information will be reviewed to update any changes in generation status from waste minimization effects, as well as, changes in regulations.

Future focus on waste mirimization efforts for operations at the INEL will be on waste avoidance. Specific objective L. . ..bstantially reduce or eliminate mixed and low-level wastes are not 
feasible based on current INEL, treatment capabilities. To meet the long-term vision of the INEL, waste generation will need to be minimized, and all wastiss will need to be treated to meet applicable requirements. To this end, : major goal of the INEL needs to be the development of mixed and low. level waste treatment capabilities. The design of the proposed MLLWTF is buing investigated to support this goal.

\subsection{Assumptions}

The following set of assumptions were used in developing the MLLWTF pioject. These assumptions relate specifically to the development of the MLLWTF at the INEL.

\subsubsection{Waste Assumpticns}

- No transuranic waste will be treated at this tacility.

- The treatment of purely hazardous waste is not being considered for this facility.

- The facility will only accept waste from INEL contractors.

- Projected low-level waste streams will be estimated using the Radioactive Waste Managgement Information System (RWMIS) database and Idaho Chemical Processing Plant (ICPP) information.

- Projected mixed waste streams will be estimated using the Waste Management Information System (WMIS) database information.

- The MLLWTF Engineering Design Files (EDFs), located in the Appendix B of this report, encompass both current and projected future waste streams generated at the INEL.

- The generic engineering design files address secondary waste streams produced by ER activities, based on ERD projections and engineering judgement. The MLLWTF project assumes that any large volumes of ER wastes are treated at the remediation site.

- The current inventory of mixed waste in storage at the INEL will be treated by the time the MLLWTF becomes operational.

- No inventory of low-level will exist at the time the MLLWTF becomes operational.

\subsubsection{Treatment Facility Assumptions}

- The treatment technologies to be considered must be proven in the nuclear industry, or commercially available and adaptable to nuclear applications, or require minimal development. Additionally, in the case of mixed waste, treatment technologies to be considered will be best demonstrated available technologies (BDATs) or will meet minirnum ERA treatment standards. 
- The resulting waste forms will be compatible with the waste acceptance criteria (WAC) for the proposed MLLWDF, or the RWMC, depending on waste type.

- The location of the MLLWTF will be witin the INEL site boundaries.

- The MLLWTF will contain a laboratory for waste characteriz?.ion.

- The MLLWTF will be designed to limit maximum radiation exposure to an individual worker to less than one fifth of the annual occujational exiernal dose-equivalent iimits (1/5 of $5 \mathrm{rem}$ or $1 \mathrm{rem})$.

- The MLLWTF will have a 25 -year design life.

- The facility will include storage space for six months throughput of incoming, untreated waste and for six months throughput of outgoing, treated waste.

\subsubsection{Other INEL Facility Assumptions}

- A permitted mixed and low-level waste disposal facility will be available when the MLLWTF becomes operational.

- The Idaho Chemical Processirg Plant (ICPP) will continue to treat liquid low-level wastes.

\subsubsection{Regulatory Assumptions}

- The regulatory environment of the future will include thc current requirements and the proposed requirements as currently drafted.

- The MLLWTF will comply with all applicable federal, state, DOE, and EG\&G requirements.

- Belıw Regulatory Concern (BRC) levels for tadionuclides estabiished by the Nuclear Regulatory Commission (NRC) are not applicable to DOE waste streams.

- The INEL will not become part of a state compact for the disposal of low-level waste, as defined in the Low-Level Radioactive Waste Policy Amendments Act.

- National Environmental Policy Act (NEPA) requirements for the MLLI'TF are assumed to be an environmental impact statement (EIS) based on the incineration echnology being the BDAT for some INEL waste streams. This requirement will be satisfied by the INEL ER\&WM EIS. 


\section{WASTE STREAM STUDIES OVERVIEW}

The waste stream studies were conducted to identify the INEL's waste streams and their potential treatment strategies. Numerous resources were used in the identification of mixed and low. level waste streams generated at the INEL. Each identified waste stream was characterized in order to determine treatment strategies. More detailed information on the waste stream studies can be found in Volume 2 of this report.

\subsection{Identification of Waste Streams}

The mixed waste streams were identified by using the WMIS database, supported by the Oak Ridge National Laboratory (ORNL). The waste streams were screened to exclude transuranic (TRU) wastes. The remaining waste streams were classified according to their generation status, i.e., still generate 1 or no longer generated. This resulted in the identification of 37 mixed waste streams. Of these waste streams, 2 will be treated by the generator, leaving 35 input mixed waste streams for the MLLWTF to treat. In identifying input waste streams, it was assumed all mixed waste currently in storage at the INEL would be treated by the time the MLLWTF becomes operational. In addition to the waste streams identified hy WMIS, an attempt was made to develop generic waste streams representing wastes occurring from spills at operating RCRA facilities and secondary waste streams that have a high probability of resulting from ER activities.

The low-level waste streams were identified using the RWMIS database. The waste streams that were identified fall into two categories: primary waste streams and secondary waste streams. The primary waste streams go directly from the generator to one of the five following processes: incineration, compaction, metal sizing, contact disposal, or remote disposal. The secondary waste streams are produced by the incineration, compaction, or metal sizing processes and sent to the RWMC for disposal. As a result of the above information, 55 low-level waste streams were identified: 1 is no longer generated, 5 represent secondary waste streams, and 1 had insufficient characterization data to recommend treatment strategies, leaving 48 low-level waste streams for the MLLWTF to treat.

\subsection{Characterization of Waste Streams}

The waste streams were characterized in order to obtain sufficient information to identify potential treatment strategies. The necessary characterization information included waste stream description, annual generation rate, hazardous constituents, radioactive characteristics, and applicable regulatory requirements.

The information supplied by the WMIS database was often lacking specific data necessary to adequately characterize the identified mixed waste streams. To obtain this missing data, generators and storage facility personnel were contacted. In the case of low-level waste, the RWMIS database was used for characterization. A summary of the characterization information can be found in Volume 2 of this report. 


\subsection{Treatment Strategies}

Treatment is conducted to reduce the waste volume, toxicity, and/or mobility of the various contaminants in the waste, and to increase stability of the final waste form. Treatment can involve either physical, chemical, or thermal processes, or combinations of these processes. Each waste stream was analyzed to determine potential treatment strategies, and reviewed by a committee of personnel with expertise in waste treatment.

The treatment strategies for mixed waste streams were driven by the Resource Conservation and Recovery Act (RCRA) Land Disposal Restrictions (LDR). For each hazardous waste, EPA was required by Congress to establish treatment standards that are protective of human health and the environment when the wastes are land disposed. The treatment standards either (1) require the use of one or more specified treatment technologies, or (2) they require that wastes be treated to meet specified concentration limits on the hazardous constituents. These two options are known as technology-based and concentration-based standards, respectively. Where concentration-based standards are used, EPA assumes the waste is treated with the Best Demonstrated Available Technology (BDAT). However, the wastes can be treated by any technology as long as the treatment residues do not exceed the concentration limits obtained using the BDAT.

Where possible, waste stream treatment strategies were recommended in accordance with the established treatment standards, and recommendations provided in the EPA treatment technology background documents. Most of the INEL mixed waste strearns are regulated by concentration-based treatment standards. As a minimum, applicable BDATs were recommended for these wastes. Where potential for recycle or reuse existed, or in the case of concentration-based treatment standards where other applicable technologies could be used, these options were proposed.

For low-level waste, treatment is used to maximize the longevity of existing and proposed disposal sites through volume reduction, as well as creating a more stable final waste form.

A summary of the treatment strategies proposed is presented in Volume 2 of this report. 


\section{ENVIRONMENTAL REGULATORY REQUIREMENTS OVERVIEW}

DOE facilities are required to manage their radioactive wastes in accordance with DOE Orders developed to carry out the authority granted by the Atomic Energy Act (AEA). DOE is exempt from Nuclear Regulatory Commission (NRC) regulations except as specified in Section 202 of the Energy Reorganization Act of 1974, e.g., DOE facilities that accept commercial high-level waste are licensed by the NRC. The MLLWTF will not accept high-level waste, so it is not governed by NRC regulations. The radioactive component of mixed and low-level waste is subject to the requirements of DOE 5820.2A, "Radioactive Waste Management." Chapter III establishes the policies and guidelines for managing low-level waste and specifies criteria for site selection, design, and disposal site operations. This order provides for treating low-level wastes to ensure that the disposal facility meets acceptable performance objectives.

Hazardous wastes must be managed in compliance with regulations promulgated by the EPA under RCRA, Subtitle $C$, which sets the regulatory requirements for the hazardous waste management program by governing the conduct of generators and transporters of hazardous waste and owners and operators of TSD facilities. DOE policy is, as stated in DOE 5400.3, "Hazardous and Radioactive Mixed Waste Program," is to manage all departmental hazardous and radioactive mixed wa: tes according to the requirements of Subtitle C of RCRA, and the AEA, respectively. RCRA applies to the extent that it is not consistent with the AEA.

The Hazardous and Solid Waste Amendments (HSWA) to RCRA, through the land disposal restrictions (LDRs), prohibit disposal of hazardous and mixed wastes that have not been treated to standards required by EPA in 40 CFR 268. HSWA also prohibits the storage of any LDR waste unless the storage "is for the sole purpose of accumulating sufficient quantities in a tank or container to facilitate proper recovery, treatment, or disposal of that waste" (40 CFR 268.50). EPA has set statutory deadlines to meet these prohibitions, and non-compliance with storage or disposal standards after these dates is a direct violation of the law. All mixed waste generated at the INEL will be subject to the RCRA LDRs by May 8, 1992, with minor exceptions. Appendix A of this report contains more detailed information about these regulations.

Proper environmental planning is critical to project management because it identifies specific regulatory documents and permitting requirements. Integral to permitting is compliance with numerous regulations pertaining to facility design, process and emission controls, operating standards, effluent emission standards, and monitoring requirements. For a given project effort, a number of environmental requirements may be applicable, and compliance planning may involve complex tradeoffs of time, risk, costs, and quality. Failure to properly comply with environmental regulations and statutes invites lawsuits, delays, and loss of resources.

INEL projects must comply with applicable environmental Federal statutes, regulations, Executive Orders (EOs), DOE Orders, and guidelines that provide for the protection of human health and the environment. The INEL Mixed and Low-Level Waste Treatment Facility Environmental Compliance Plan and Schedule, contained in Appendix A of this report, compiles a survey of the primary Federal, State of Idaho, and DOE environmental protection regulations and standards applicable to the siting, construction, and operation of the MLLWTF. This compilation will facilitate environmental compliance planning and may be regarded as a "road map" for the types 
of environmental controls and compliance documentation required for successful fulfillment of the MLLWTF mission. Although this plan does not address all pending legislation or regulations that may become effective in the fuiure, DOE recognizes that the regulatory environment is changing rapidly and that construction and operation of the MLLWTF must be conducted in compliance with the statutes, regulations, and standards then in effect. Table 1 contains proposed environmental regulations that may impact the MLLWTF.

The MLLWTF permitting and approval summary is contained in Table 2. It addresses applicable permits, regulatory citations, requirements, and review or approval chains. The MLLWTF environmental compliance schedule is contained in Figure 1. This schedule shows a time-line relating project phases to permitting time frames. 
Table 1. Proposed federal regulations which may impact the mixed and low-level waste treatment facility.

\begin{tabular}{|c|c|c|c|}
\hline Effected regulation & Title & Proposed action & Final rulemaking \\
\hline 40 CFR 264 & $\begin{array}{l}\text { Location Standards for TSD } \\
\text { Facilities }\end{array}$ & $\begin{array}{l}\text { EPA plans to propose additional standards } \\
\text { for location of TSD facilities in a variety of } \\
\text { sensitive environments. }\end{array}$ & $\begin{array}{l}3 / 94 \\
\text { (Proposed } \\
\text { rulemaking 3/92) }\end{array}$ \\
\hline 40 CFR 264 & $\begin{array}{l}\text { Air Emission Standards for Volatile } \\
\text { Organics at TSD Facilities }\end{array}$ & $\begin{array}{l}\text { This standard will require organic emissions } \\
\text { controls for areas where containers of } \\
\text { hazardous waste have a volatile organic } \\
\text { concentration equal to or greater than } 500 \\
\text { ppm by weight. }\end{array}$ & $7 / 92$ \\
\hline 40 CFR 268 & $\begin{array}{l}\text { Treatment and Disposal of } \\
\text { Contaminated Debris (LDRs . } \\
\text { Phase I) }\end{array}$ & $\begin{array}{l}\text { EPA requests data and comments on } \\
\text { BDATs and treatment capacities for newly } \\
\text { identified wastes and modifications } 10 \\
\text { existing treatment standards for various } \\
\text { wasies. }\end{array}$ & $5 / 92$ \\
\hline 40 CFR 264 & $\begin{array}{l}\text { Emission Controls for Hazardous } \\
\text { Waste Incinerators }\end{array}$ & $\begin{array}{l}\text { EPA proposes to amend the hazardous } \\
\text { waste incinerator regulations to improve } \\
\text { control of toxic metal, hydrogen chloride, } \\
\text { and residual organic emissions. They also } \\
\text { plan to define plasma arc and infrared } \\
\text { incinerators; regulate carbon regeneration } \\
\text { units as thermal treatment devices; and } \\
\text { make minor revisions to permitting } \\
\text { procedures. }\end{array}$ & $6 / 92$ \\
\hline 40 CFR 261 & Management of Used Oil & $\begin{array}{l}\text { EPA will make the final decision on } \\
\text { whether or not to list used oils as hazardous } \\
\text { waste. }\end{array}$ & $5 / 92$ \\
\hline 40 CFR 261 & $\begin{array}{l}\text { Identification and Listing of } \\
\text { Hazardous Wastes - De minimis } \\
\text { Exemption Levels }\end{array}$ & $\begin{array}{l}\text { EPA will propose exemptions from } \\
\text { regulation for any currenily listed wastes } \\
\text { that are not hazardous because the } \\
\text { hazardous constituents are present at levels } \\
\text { lower than the concentration levels } \\
\text { established by this rule. In addition, EPA } \\
\text { will propose to modify some of the numeric } \\
\text { treatment standards listed in the LDRs. }\end{array}$ & $\begin{array}{l}\text { Proposed } \\
\text { rulemaking } 8 / 92\end{array}$ \\
\hline 40 CFR $122-125$ & Revisions to NPDES regulations & $\begin{array}{l}\text { EPA will propose revisions to the NPDES } \\
\text { regulations to clarify existing requirements } \\
\text { and policies. }\end{array}$ & $5 / 93$ \\
\hline 40 CFR 50.12 & NAAQS - Lead & $\begin{array}{l}\text { EPA is assessing new heaith effects } \\
\text { information on lead and will make a } \\
\text { decision for or against a change in the } \\
\text { NAAQS. }\end{array}$ & $5 / 92$ \\
\hline 40 CFR $51 \& 52$ & $\begin{array}{l}\text { Prevention of Significant } \\
\text { Deterioration (PSD) and New } \\
\text { Source Review (NSR) }\end{array}$ & $\begin{array}{l}\text { EPA will propose to amend existing new } \\
\text { source review regulations, including PSD to } \\
\text { conform to the CAA Amendments of } 1990 \text {. }\end{array}$ & $4 / 92$ \\
\hline
\end{tabular}


Table 1. (continued).

\begin{tabular}{|c|c|c|c|}
\hline Effected regulation & Title & Proposed action & Final rulemaking \\
\hline 40 CFR 63 & $\begin{array}{l}\text { General Provisions for Major and } \\
\text { Area Sources of Air Toxics }\end{array}$ & $\begin{array}{l}\text { General provisions are being developed } \\
\text { which will include standards for } 189 \\
\text { hazardous air pollutants to be regulated } \\
\text { under Section } 112 \text { of the CAA } \\
\text { Amendments. }\end{array}$ & $11 / 92$ \\
\hline $40 \mathrm{CFR} 761$ & PCBs Disposal Amendments & $\begin{array}{l}\text { EPA is considering amending its TSCA } \\
\text { PCB disposal regulations to address } \\
\text { alternative methods to those currently } \\
\text { permitted, and regulatory requirements for } \\
\text { existing classes of PCB and PCB items. }\end{array}$ & $5 / 92$ \\
\hline 50 CFR 17 & $\begin{array}{l}\text { Endangered and Threatened } \\
\text { Wildlife - Bald Eagle }\end{array}$ & $\begin{array}{l}\text { The FWS will propose a regulation dealing } \\
\text { with the possible delisting, downlisting, or } \\
\text { reclassification of the bald eagle from } \\
\text { endangered to threatened. }\end{array}$ & $\begin{array}{l}\text { Proposed } \\
\text { rulemaking 2/92 }\end{array}$ \\
\hline 40 CFR 193 \& 764 & $\begin{array}{l}\text { Environmenta! Protection } \\
\text { Standards for LLW Disposal }\end{array}$ & $\begin{array}{l}\text { EPA intends to develop environmental } \\
\text { radiation protection standards for LL.W } \\
\text { disposal to protect the public health and } \\
\text { environment from potential adverse effects } \\
\text { of this activity. }\end{array}$ & $\begin{array}{l}\text { Proposed } \\
\text { rulemaking on hold } \\
\text { pending resolution } \\
\text { with NRC. }\end{array}$ \\
\hline 10 CFR $2 \& 20$ & LLW Below Regulatory Concern & $\begin{array}{l}\text { NRC may amend its regulations to address } \\
\text { radioactive waste disposal when low } \\
\text { radioactive quantities do not meril } \\
\text { regulation as radioactive material. }\end{array}$ & $\begin{array}{l}\text { Proposed } \\
\text { rulemaking on hold }\end{array}$ \\
\hline 10 CFR 20 & $\begin{array}{l}\text { Incineration of Low-Level } \\
\text { Radioactively Contaminated Waste } \\
\text { Oil from Nuclear Power Plants }\end{array}$ & $\begin{array}{l}\text { NRC proposes to amend its regulations to } \\
\text { permit onsite incineration of slightly } \\
\text { contaminated waste oils generated at } \\
\text { licensed nuclear power plants. }\end{array}$ & Final rule on hold. \\
\hline 10 CFR $20 \& 61$ & $\begin{array}{l}\text { Low-Level Waste Manifest } \\
\text { Information and Reporting }\end{array}$ & $\begin{array}{l}\text { NRC will propose changes to manifesting } \\
\text { requirements for shipments of LLW to } \\
\text { disposal facilities. }\end{array}$ & $1 / 93$ \\
\hline 10 CFR 1021 & DOE Compliance with NEPA & $\begin{array}{l}\text { DOE proposes to revise the rule on } \\
\text { compliance with NEPA to incorporate } \\
\text { revised provisions of DOEs guidelines for } \\
\text { implementing the procedural provisions of } \\
\text { NEPA. }\end{array}$ & 1291 \\
\hline
\end{tabular}


Table 2. Attachment 1-INEL MLLWTF permitting and approval summary.

\begin{tabular}{|c|c|c|c|c|}
\hline $\begin{array}{l}\text { Applicable } \\
\text { permits }\end{array}$ & $\begin{array}{l}\text { Regulatory permit } \\
\text { citation }\end{array}$ & Requirements & Review/approval & Comments \\
\hline PTC/PSD & $\begin{array}{l}\text { IDAPA } \\
16.01 .1012\end{array}$ & $\begin{array}{l}\text { Site plans, descriptions, and drawings } \\
\text { showing design of stationary source, } \\
\text { the nature and amount of emissions, } \\
\text { and manner it will Le operated and } \\
\text { controlled. Schedule for } \\
\text { construction. Continuous emission } \\
\text { control system description, emission } \\
\text { estimates. Analysis of effect on air } \\
\text { quality. Title II design parameters. } \\
\text { NESHAP analysis. }\end{array}$ & $\begin{array}{l}\text { CEO } \\
\text { DOE-ID } \\
\text { IAQB }\end{array}$ & $\begin{array}{l}\text { If a NESHAP approval is } \\
\text { required from EPA, it must } \\
\text { be obtained prior to } \\
\text { submittal of the PTC/PSD } \\
\text { permit application to the } \\
\text { State of Idaho. }\end{array}$ \\
\hline $\begin{array}{l}\text { Operating } \\
\text { permit }\end{array}$ & $\begin{array}{l}\text { IDAPA } \\
16.10 .1012\end{array}$ & $\begin{array}{l}\text { Description of emission reduction } \\
\text { credits proposed for use, including } \\
\text { descriptions of the stationary sources } \\
\text { providing the reductions, a } \\
\text { description of the system of } \\
\text { continuous emission control, and } \\
\text { ernission estimates. For alternative }\end{array}$ & $\begin{array}{l}\text { CEO } \\
\text { DOE-ID } \\
\text { IAQB }\end{array}$ & $\begin{array}{l}\text { DOE.ID plans to obtain an } \\
\text { operating permit for all } \\
\text { existing facilities on the } \\
\text { INEL. New facilities will be } \\
\text { a moditication of this } \\
\text { operating permit. }\end{array}$ \\
\hline
\end{tabular}

emission limits or emission oftsets,

information on the air quality

impacts of the traded emissions as necessary.

PCB

incinerator

40 CFR 761

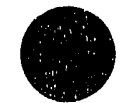

NPDES

40 CFR 122

RCRA

40 CFR 270

IDAPA

NESHAP

40 CFR 61
Location of incinerator. Detailed design of incinerator. Engineering reports on anticipated performance of incinerator. Sampling and monitoring equipment available. Waste volumes expected. Any local, State, or Federal permits or approvais. Schedules/plans for environmental compliance.

May be permitted under a group permit or individually; or the facility may be covered under a promulgated storm water general permit. The permit application should include: site map showing topography; drainage area of each storm water outfall; areas where surface waters receive run-off.

Permits are required for $>90$ day storage facility, or treatment/disposal facility for RCRA hazardous waste. Part B permit includes: waste analysis plan, security procedures, inspection sched:, contingency plan, training plan, a. 'd closure plan.

Location, description, nature, size, design, capacity, and method of operation of the source, including a description of emission control equipment. Detailed emission estimates. Types and annual quantity of radionuclides emitted. Hazardous pollutant emission points. Estimated dose equivalent rate. Control devices and estimated control efficiencies.

\section{CEO}

DOE-ID

EPA

DOE-ID

EPA

\section{CEO}

DOE-ID

HMB

CEO

DOE-ID

EPA
For a new facility, Part A and $B$ are submitted logether.

Beginning October 1, 1992 , NPDES permitting will be required for storm water discharges at the INEL. New facilities will be a modification of the general NPDES permil.$$
\text { . }
$$ 
Table 2. (continued).

\begin{tabular}{|c|c|c|c|c|}
\hline $\begin{array}{l}\text { Applicable } \\
\text { permits }\end{array}$ & $\begin{array}{l}\text { Regulatory permit } \\
\text { citation }\end{array}$ & Requirements & Review/approval & Comments \\
\hline $\begin{array}{l}\text { Nonhazardous } \\
\text { wastewater } \\
\text { treatment } \\
\text { (except land } \\
\text { application) }\end{array}$ & DOE Order 5400.1 & $\begin{array}{l}\text { Plans and specifications. Follow } \\
\text { requirements of IDAPA } 16.01 .2000 \text {. }\end{array}$ & $\begin{array}{l}\text { CEO } \\
\text { DOE-ID } \\
\text { IDHW-DEQ }\end{array}$ & · \\
\hline $\begin{array}{l}\text { Production } \\
\text { water well }\end{array}$ & $\begin{array}{l}\text { DOE Orders } \\
5400: 1 \\
5480.1 \\
5380.4 \\
\text { IDAPA } \\
16.01 .8601 .01\end{array}$ & $\begin{array}{l}\text { Title II well cc nstruction design: well } \\
\text { location, sample and tap, discharge } \\
\text { tap, well casing vent specification, } \\
\text { casing seal requirements, sealing well } \\
\text { to formation, gravel packs and } \\
\text { screens, well-house floor drains, and } \\
\text { well-house protection from flooding. }\end{array}$ & $\begin{array}{l}\text { CEO } \\
\text { DOE-ID } \\
\text { IDHW-DEQ }\end{array}$ & $\begin{array}{l}\text { Specifications must meet } \\
\text { State requirements. }\end{array}$ \\
\hline $\begin{array}{l}\text { Drinking } \\
\text { water supply }\end{array}$ & $\begin{array}{l}\text { DOE Order } \\
5400.1, \\
\text { IDAPA } \\
16.01 .8000\end{array}$ & $\begin{array}{l}\text { Plans including characterization of } \\
\text { stationary water source. Title II } \\
\text { design parameters. Storage } \\
\text { requirements; pressure ranges; } \\
\text { hydraulic analysis; adequacy, quality, } \\
\text { and availability of water source. }\end{array}$ & $\begin{array}{l}\text { CEQ } \\
\text { DOE-ID } \\
\text { ID-DEQ }\end{array}$ & \\
\hline
\end{tabular}




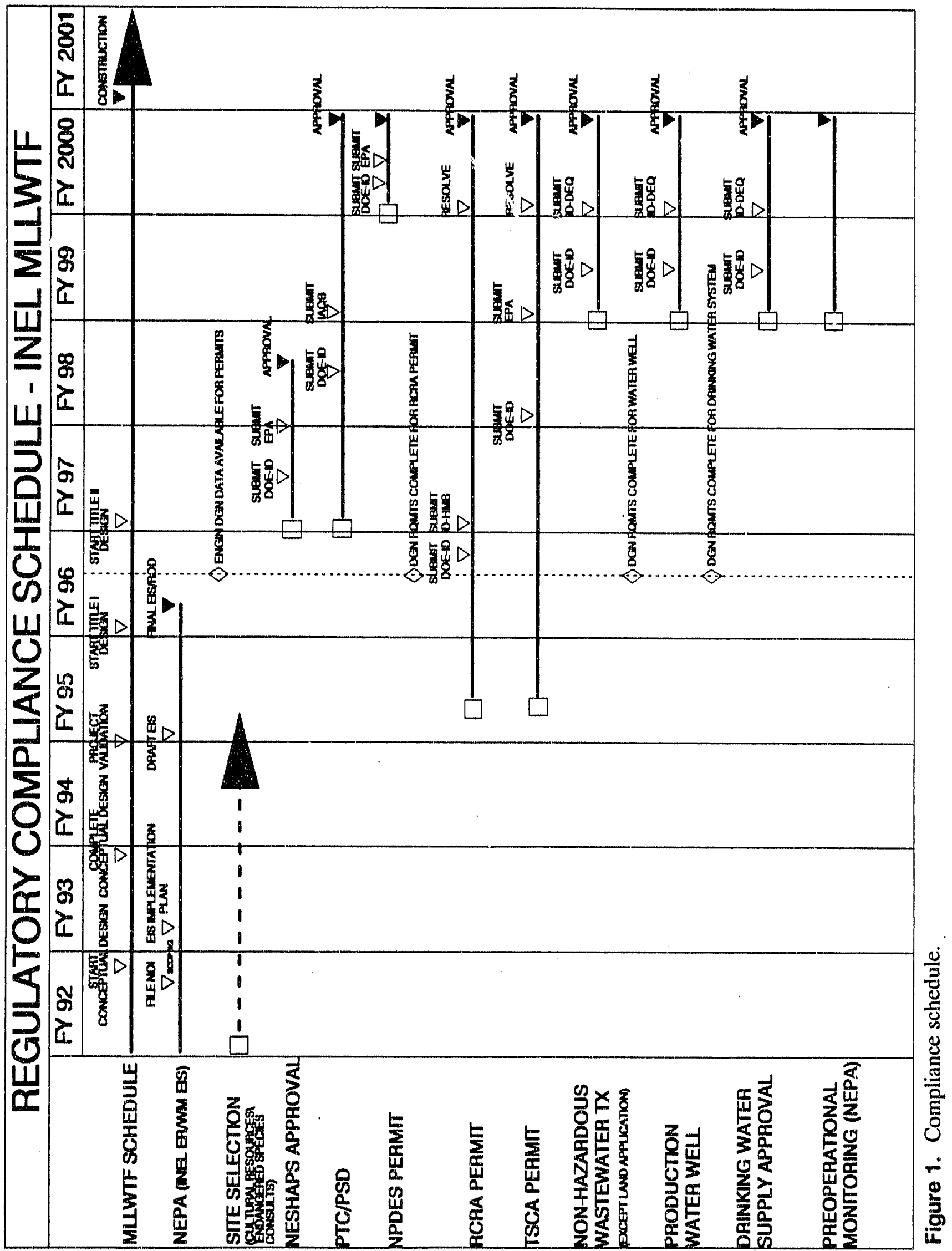




\section{NATIONAL ENVIRONMENTAL POLICY ACT OVERVIEW}

All potential projects involving any federal agency must undergo a review pursuant to the National Environmental Policy Act (NEPA) (42 USC 4321-4347) to identify and evaluate potential environmental impacts. NEPA constitutes a national policy to protect the environment and to promote a better understanding of the ecological systems and natural resources that are important to the nation. The Council on Environmental Quality (CEQ) regulations implementing NEPA contain "action-forcing" provisions to ensure that federal agencies consider environmental information prior to making decisions on proposed actions. The NEPA process includes decision points at which the significance of environmental effects are considered, project alternatives are identified, and appropriate mitigation measures are identified and adopted.

DOE Order 5440.1D, "National Environmental Policy Act Compliance Program," describes the roles of various DOE offices in implementing NEPA. It also states that DOE's policy is to comply fully with the letter and spirit of NEPA. To ensure that environmental factors are considered in the decision-making process and to promote environmentally-responsible decisions, DOE will incorporate NEPA requirements eariy in the planning process for proposed actions. DOE will also coordinate its NEPA activities with the states that host DOE facilities. DOE is committed to complete assessment and full disclosure of the environmental consequences of its proposed actions.

DOE-ID Order 5440.1, "Implementation of the National Environmental Policy Act," is a Supplemental Directive (SD) establishing the DOE-ID authorities, responsibilities, local guidance, and direction for the implementation of DOE Order 5440.1D. The National Environmental Policy Act Requirements and Options For the Mixed and Low-Level Waste Treatment Facility report, November 1991, is contained in Appendix A of this report.

The proposed MLLWTF project would result in the construction and operation of a large scale project. Activity Data Sheet 5E-2 lists the rough order of magnitude (ROM) cost for the MLLWTF at $\$ 125$ million dollars. Candidate treatment processes include a high temperature incineration-type process designed to process combustible waste and treat mixed wastes to the best demonstrated available technology (BDAT) standards set by the EPA. The proposed action would be considered a "major federal action" with effects that might be significant and that are potentially subject to federal control and responsibility. The MLLWTF would, therefore, most likely require the preparation of an Environmental Impact Statement (EIS).

\subsection{NEPA Strategy for the MLLWTF}

The INEL strategy for compliance with NEPA includes preparation of a programmatic or dualpurpose programmatic and project-specific EIS to address existing and planned environmental restoration (ER) and waste management (WM) activities. The EIS scope includes existing and conceptually planned ER and WM programs, facilities, and activities, and analyses of the environmental risks of each program and cumulative impacts (Activity Data Sheet 76-E1). The INEL ER\&WM EIS scope excludes reactor operations and any non.ER and WM research activities. Provisions have been made to encompass the proposed MLLWTF in the ER\&WM sitewide EIS. 
A third party has negotiated a contract with DOE to prepare the INEL ER\&WM EIS. A notice of intent (NOI) has been drafted and is currently in review at DOE-ID. Following review and approval, the NOI will be published in the Federal Register (FR), initiating the scoping process and the period of public involvement. The latest schedule for the ER\&WM EIS calls for completion of the final EIS by January 1, 1996. The record of decision (ROD) is scheduled to be published by August 1, 1996.

An alternative to including the MLLWTF in the INEL ER\&WM EIS would be to prepare a project level EIS. At this time, this alternative is not being considered. Figure 2 shows a schedule for the INEL ER\&WM EIS process and a proposed project level EIS in relation to the project schedule for the MLLWTF (as of January 1992). Delays in the NEPA process could impact the start of Title II design and ultimately construction and operation of the facility.

Additional environmental documentation will need to be submitted for interim project activities. These activities may include sampling and/or geophysical work done during site selection, precperational monitoring, and any cold mockups or bench scale testing. All environmental documentation must be submitted in accordance with the Environmental Compliance Planning Manual (DOE/ID 10166 Revision 3, 4/91) and EG\&G Idaho Company Procedure 8.5, "Preparation and Approval of NEPA Documentation."

At this time, the INEL ER\&WM EIS is assumed to include the MLLWTF, although project level documentation for specific activities will still be required. Several activities are needed to support the sitewide EIS and include: identification of waste streams and definition of source terms; waste treatment tradeoff studies and identification of candidate treatment processes; hazard and risk assessments; evaluation of siting criteria; and development of a conceptual design. 


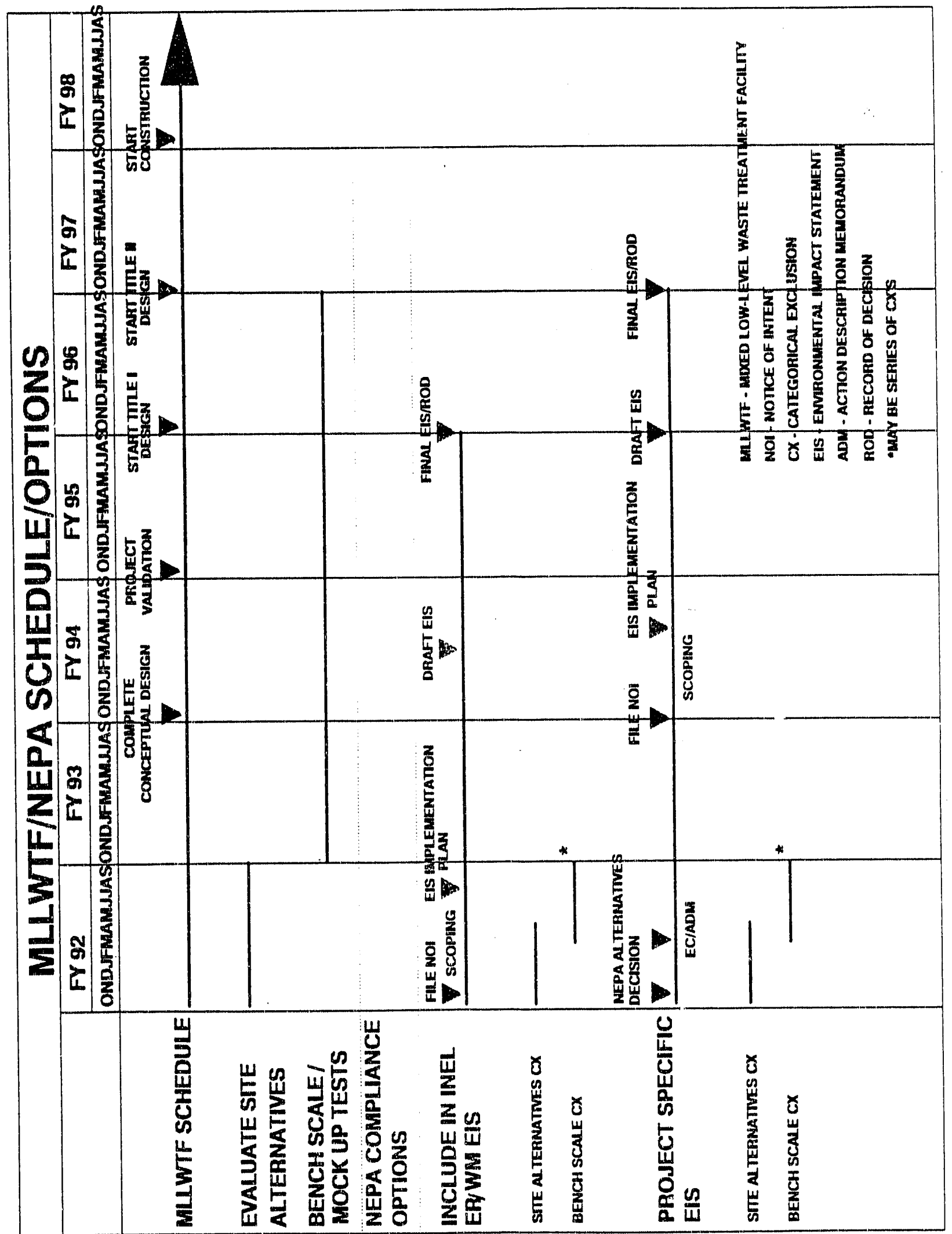




\section{SITING REQUIREMENTS OVERVIEW}

The physical location of a TSD facility directly influences the potential for irnpacting human health and the environment. Physical locations refer to the geologic, hydrologic, and pedologic characteristics of a site, as well as adjoining lands, surface water, and ground water that may be impacted in the event that hazardous and/or radiological constituents are released lirom the facility. A 1983 EPA study concluded that proper site selection and appropriate hydrologic and geologic conditions are important factors in maintaining long-term protection of the environment.

The first step taken in selecting a site for the proposed MLLWTF is to assume that the facility would be located at the INEL and thius, the region of interest is the 8.90 square miles comprising the INEL. The INEL is located near Idaho Falls, in the Eastern Snake River Plain. The dominant geologic features of the Snake River plain were formed by volcanism. However, the plain is bordered by basin and range mountains that were created by normal faults.

The siting of the proposed MLLWTF will be accomplished by excluding all sites on the INEL that do not meet the mandatory requirenents (i.e., "Go/No-Go"). The remaining sites will then be rated according to various differentiating criteria that will impact site selection, but that are not strict requirements. Risk factors will be assigned to these criteria based on their probability and seriousness and will be used in the final decision-making process.

The siting requirements for the proposed MLLWTF at the INEL are based on the following applicable EPA regulations and DOE Orders:

- $\quad 40$ CFR 264.18, "Location Standards"

- $\quad 40$ CFR 270.14, "Contents of Part B: General Requirements"

- National Historic Preservation Act (16 USC 470 et seq.)

- Endangered Species Act (16́ USC 1531 et seq.)

- Toxic Substances Control Act (15 USC 2601 et seq.)

- Clean Air Act (42 USC 7401 et seq.)

- DOE Order 6430.1A., "General Design Criteria."

Preliminary Siting Requirements for the Proposed Mixed and Low-Level Waste Treatment Facility at the Idaho National Engineering Laboratory, EGG-WM-10155, is contained in Appendix A of this report.

\subsection{Siting Criteria}

The following list of mandatory requirements is applicable to the INEL for location of the proposed MLLWTF, as determined fiom EPA regulations and DOE Orders. 
- The MLLWTF cannot be located at a site below the 100 -year flood water elevation if the facility contains PCBs or PCB items with concentrations of $50 \mathrm{ppm}$ or greater.

- If the MLLWTF does not store PCBs or PCB items, but does store RCRA hazardous or mixed waste, it cannot be located in the 100-year floodplain unless it meets one of the three conditions implemented in 40 CFR 264.18.

- If the MLLWTF is located in Bingham, Bonneville, Clark, or Jefferson county, portions of the facility where treatment, storage, or disposal of hazardous waste will be conducted cannot be located within 61 meters ( 200 leet) of a fault that has displaced during the last 10,000 years.

- The MLLWTF cannot have any direct adverse impacts on sites listed, or eligible for listing, on the National Register of Historic Places.

- The MLLWTF cannot be located within an endangered or threatened species habitat.

- The MLLWTF cannot be located in a site such that air emissions from the facility will visibly impair any Class I air quality area.

- The MLLWTF will be located so that the maximum calculated dose from exposure to internally deposited radioactive materials and/or radiation from external sources to offsite individuals shall not exceed the limits identified in DOE Order 6430.1 A.

- The MLLWTF cannot be located on a site traversed by buried pipe utilities unless it meets the requirements in DOE Order 6430.1A.

- The MLLWTF cannot be located on a site that would adversely affect the operation of other facilities.

The following are additional requirements from DOE Orders that are not mandatory, but should be considered when siting the proposed MLLWTF.

- The location of existing RCRA and/or CERCLA sites shall be avoided when siting the MLLWTF.

- The adequacy of existing or planned support and service facilities shall be considered when siting the MLLWTF.

- The 500-year floodplain shall be avoided when siting the MLLWTF.

" Wetlands shall be avoided when siting the MLLWTF.

- Seismic zones shall be avoided when siting the MLLWTF.

- The remoteness from site boundaries shall be considered when siting the MLLWTF. 
- The distance to waste generators shall be considered when siting the MLLWTF.

- The effects of Department of Transportation regulations on the transport of waste to and from the MLLWTF shall be considered when siting the MLLWTF.

- The slope of the land surface and corresponding energy available for erosion shall be considered when siting the MLLWTF.

- The distance from volcanic exclusion zones shall be considered when siting the MLLWTF.

- The commuting distance to th MLLWTF shall be considered when siting the MLLWTF.

- The costs of installing new utilities and roads shall be sonsidered when siting the MLLWTF.

- The ability of the site to be fully characterized (i.e., not a complex ge ological location) shall be considered when siting the MLLWTF.

- The location of unexploded ordnance should be considered when siting the MLLWTF.

- The co-location of the MLLWTF with other proposed facilities at the INEL shall be considered when siting the MLLWTF.

The final decision-making process will be a combination of excluding all sites that do not meet the mandatory requirements, and ranking all remaining sites, with respect to each other, by their abilities to meet the differentiating criteria. This process will be developed in the final siting report for the MLLWTF. 


\section{HEALTH AND SAFETY CRITERIA OVERVIEW}

The operations at a waste treatment facility involve potential health and safety risks, which must be considered in the facility design. The candidate waste feed streams and the respective technologies used to process them also have health and safety risks associated with them. Knowledge of these risks may affect the selection of operations to be conducted at the facility. Safety hazards may result in accidents that could prevent operation of the facility, cause harm to personnel, or increase the cost of operation; therefore, the facility should be designed to minimize safety risk. To adequately address this concern, health and safety issues must be investigated for the potential waste streams and treatment technologies at the proposed MLLWTF located at the INEL.

A general study was conducted to identify health and safety considerations applicable to potential operations at the proposed MLLWTF. These considerations were separated into two groups: those applicable to the overall facility and those applicable to the chemical constituents contained in the waste feed streams. The results of this study are reported in Health and Safety Criteria Overview for the Mixed and Low-Level Waste Treatment Facility at the Idaho National Engineering Laboratory, contained in Appendix A to this report. Although many issues were identified in this report, proper design of the facility can alleviate the potential problems. Therefore, vased on the information known at this point in the project, no irresolvable health and safety issues have been identified.

General health and safety observations made for the proposed MLLWTF include:

- Adequate sampling and personnel monitoring must be conducted to minimize exposure from hazardous and radioactive contaminants.

- Proper industrial hygiene and safety practices and procedures must be implemented, at a minimum, for hazard communication, emergency action, occupational exposure, and hazardous waste operations.

- $\quad$ Personnel training must be conducted to meet all health and safety requirements.

A detailed study has been initiated to develop and evaluate health and safety criteria for potential waste feed streams and their associated treatment technologies. The criteria that should be considered in this study include, but are not limited to, personnel exposure to chemicals and ionizing radiation, carcinogenicity, noise, heat stress, cold exposure, oxygen deficiency, biological hazards, safety and electrical hazards, fire and explosion hazards, reactivity of chemicals, safe handling practices, and ergonomic stress. Additional information about the detailed study is contained in Appendix $\mathrm{A}$ to this report. The results of this detailed study will be reported upon completion of the investigation.

The purpose of these studies are to identify potential health and safety problems associated with the entire facility, such as personnel exposure, waste handling, and waste storage, as well as health and safety problems associated with specific waste feed streams and treatment technologies. The information obtained from these studies will be used to assist with system tradeoff studies, and the conceptual design phase of this project if it is deemed to be feasible. 


\title{
Mixed and Low-Level Waste Treatment Facility Project
}

\author{
Volume 2 \\ Waste Stream Technical Summary
}

(Draft)

\author{
Published April 1992 \\ Idaho National Engineering Laboratory \\ EG\&G Idaho, Inc. \\ Idaho Falls, Idaho 83415
}

Prepared for the

U.S. Department of Energy

Office of Environmental Restoration and Waste Management

Under DOE Idaho Fleld Office

Contract DE-AC07-76ID01570 


\section{CONTENTS}

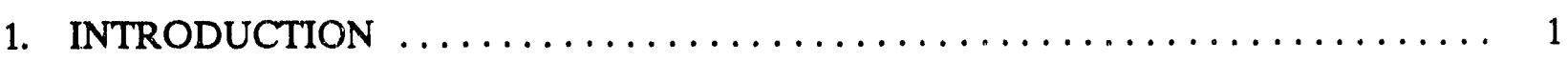

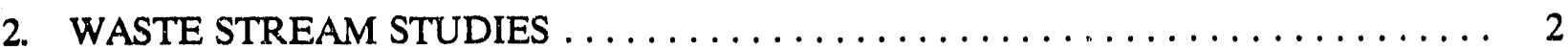

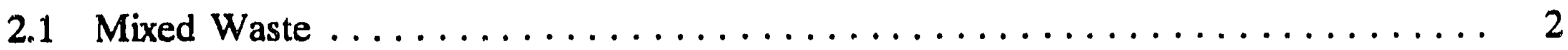

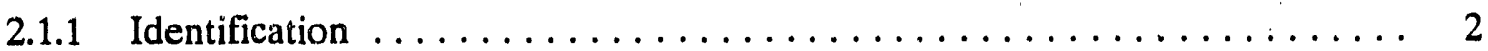

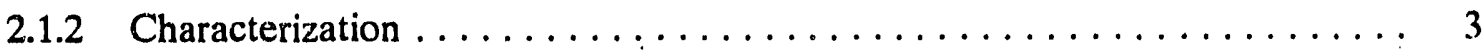

2.1.3 Potential Treatment Strategies $\ldots \ldots \ldots \ldots \ldots \ldots \ldots \ldots \ldots \ldots \ldots \ldots$

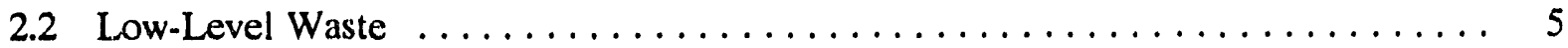

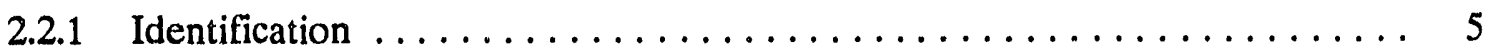

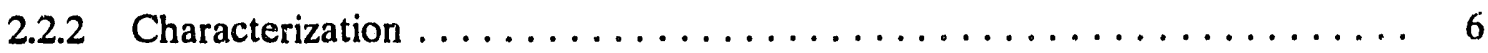

2.2 .3 Potential Treatment Strategies $\ldots \ldots \ldots \ldots \ldots \ldots \ldots \ldots \ldots \ldots \ldots \ldots$

3. SUMMARY AND OBSERVATIONS $\ldots \ldots \ldots \ldots \ldots \ldots \ldots \ldots \ldots \ldots \ldots$

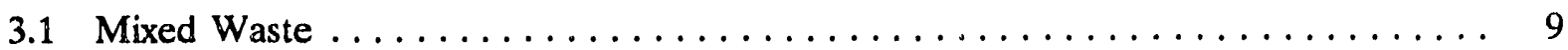

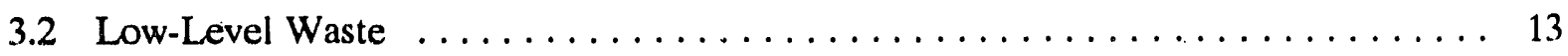

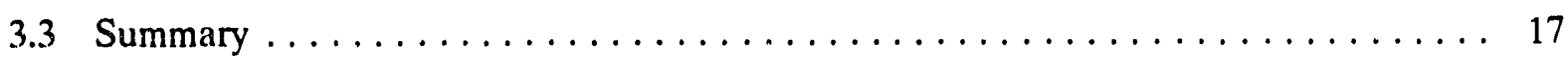

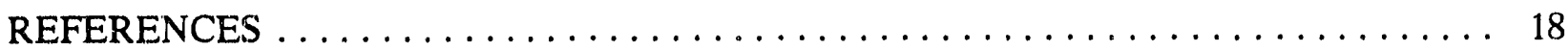

\section{FIGURES}

1. Current low-level waste treatment practices $\ldots \ldots \ldots \ldots \ldots \ldots \ldots \ldots \ldots \ldots$

2. Low-level waste destinations $\ldots \ldots \ldots \ldots \ldots \ldots \ldots \ldots \ldots \ldots \ldots \ldots \ldots \ldots \ldots$

3. RCRA categories of mixed wastes at the INEL $\ldots \ldots \ldots \ldots \ldots \ldots \ldots \ldots \ldots$

4. Radiation levels for handling of mixed wastes at the INEL $\ldots \ldots \ldots \ldots \ldots \ldots \ldots$

5. Physical form of mixed wastes at the INEL $\ldots \ldots \ldots \ldots \ldots \ldots \ldots \ldots \ldots \ldots \ldots$

6. Combustible categories of mixed waste at the INEL $\ldots \ldots \ldots \ldots \ldots \ldots \ldots \ldots \ldots$

7. Distribution of the 10 highest volume low-level waste streams, by percent volume $\ldots \ldots 14$

8. Low-level waste bypassing treatment at the INEL, by percent volume $\ldots \ldots \ldots \ldots \ldots$ 
9. Low-level waste bypassing treatment at the INEL, by percent curie content $\ldots \ldots \ldots \ldots 15$

10. Combustible categories of low-level waste at the INEL $\ldots \ldots \ldots \ldots \ldots \ldots$

11. Radiation levels for handling of low-level waste $\ldots \ldots \ldots \ldots \ldots \ldots \ldots$

\section{TABLES}

1. Hazardous constituents found in INEL mixed waste streams $\ldots \ldots \ldots \ldots \ldots \ldots$

2. Hazardous consticuents in INEL mixed waste streams, and their treatment standards

3. Summary of mixed waste stream identification, characterization and treatment strategies

4. Summary table for low-level waste stream identification, characterization and treatment strategies 


\section{Mixed and Low-Level Waste Treatment Facility Project}

\section{Volume 2 \\ Waste Stream Technical Summary}

\section{INTRODUCTION}

The preengineering studies documented in this report identify the INEL mixed and low-level waste streams, potential treatment strategies, and the requirements imposed on those waste streams and the facility(s) that will process them. The waste stream studies, which are summarized in this volume, identify the INEL mixed and low-level waste streams, the accumulated waste characterization data, regulatory treatment requirements, and proposed potential treatment strategies.

The Purpose of this volume of the report is to summarize the INEL mixed and low-level waste stream effort. Section 2 of this volume summarizes the rationale and approach which were used and describes how the waste streams were identified, information was gathered in order to recommend treatment strategies, and the rationale used to develop potential treatment strategies. Section 3 of this volume summarizes general observations concerning the nature of the INEL mixed and low-level waste streams and their treatment strategies. 


\section{WASTE STREAM STUDIES}

Based on the assumptions presented in Volume 1, Program Summary Information, the scope of the waste stream studies addresses mixed and low-level waste streams generated by INEL facilities, and secondary waste streams produced by Environmental Restoration Projects (ERP). Transuranic wastes were not considered for this study, since they are to be treated at the proposed Idaho Waste Processing Facility (IWPF).

Various resources were used to identify mixed and low-level waste streams generated at the INEL. Presently-generated waste streams were used to forecast future waste streams. The currently generated volumes of these wastes were assumed to be representative of the volumes to be generated in the future. No waste minimization activities were included in these predictions. In order to determine treatment options, a description of the waste, its composition, applicable regulatory treatment requirements, and annual generation rate was required. After characterization data were obtained, each waste stream was analyzed to determine potential treatment strategies, and reviewed by a committee with applicable knowledge of waste treatment. This information was then documented in engineering design files (EDFs), which are summarized in the attached tables.

\subsection{Mixed Waste}

Mixed Waste is defined under RCRA regulations as waste which contains a mixture of radioactive and hazardous constituents. A hazardous waste can be categorized as either characteristic or listed. Characteristic wastes are represented by an EPA-assigned code of DXXX, where XXX is a 3-digit number to identify the specific constituent or characteristic of the waste. These mixed wastes can be disposed of as radioactive waste once treated to EPA standards. Listed wastes use a similar code, but instead of the "D" prefix, an "F," "P," "K" or "U" prefix is used. Most mixed wastes at the INEL are either characteristic (DXXX), or listed spent solvents and dioxin wastes (FXXX). ${ }^{1}$ Listed wastes must be disposed of in a Resource Conservation and Recovery Act (RCRA) Subtitle Cpermitted facility after treatment, unless they have been delisted.

\subsubsection{Identification}

The mixed waste streams were identified by using the Waste Management Information System (WMIS) database, supported by Oak Ridge National Laboratory. INEL waste generators are required to submit information on their waste streams to WMIS. The waste streams addressed in this study are based on a WMIS report, dated October 30, 1991. When errors or potential discrepancies were identified in the WMIS data, they were corrected by contacting the generator or storage facility personnel. The waste streams were screened to exclude all wastes that were transuranic (TRU). The remaining 98 waste streams were classified according to their generation status - still, or no longer generated. Sixty-two waste streams are no longer generated, but some inventory is in storage awaiting treatment. Thirty-seven waste streams remained, that are currently generated at the INEL. Stored waste streams that are no longer generated were not included in the scope of this study, since temporary interim treatment capability will be provided before this project achieves its treatment milestones. Hence, 37 mixed waste streams were addressed by this study. 
In addition to these 37 waste streams, generic waste streams were developed to represent wastes not addressed by the renerators' data submissions to WMIS for ongoing wastes. The generic waste streams were developed to deal with potential spills at operating facilities, and secondary waste streams that have a high probability of being produced by Environmental Restoration Department (ERD) activities. The generic wastes were identified as (1) aquen!s wastes, (2) soils, sludges, and slurries, (3) ion exchange resins, (4) clay zeolites, (5) activated carbon, and (6) polychlorobiphenyls (PCBs).

A listing of the identified ongoing mixed and generic waste streams is provided in Table 3 , at the end of this volume. The currently generated waste streams are listed by volume, from highest to lowest annual generation rate in cubic meters, followed by the generic waste streams.

\subsubsection{Characterization}

Often, the information supplied by the WMIS database did not adequately explain the contents of each waste stream for the development of potential treatment alternatives. Data concerning hazardous constituents, radionuclide content, and their respective concentrations were often missing or incomplete. Generation and storage facility personnel were contacted to obtain a better description of the waste for each waste stream. The information requested from the generators or derived from shipping records was an accurate description of the waste, annual generation rate, quantity stored, storage location, radionuclide content, and the concentrations of contaminants in the waste. Based on the hazardous constituents present, the United States Environmental Protection Agency's (USEPA) hazardous waste codes were assigned to each waste stream. Waste streams in storage, which are no longer generated, were not characterized. Shipping records, manifests, and memos of conversation are referenced in the Engineering Design Files (EDFs) found in Appendix B, Part 1.

Engineering judgment was used to define the generic waste streams. The characterization data for these waste streams were developed using several criteria: (1) the media (e.g., soil, sludge, aqueous solutions, etc) could be contaminated with any hazardous constituent identified in the currently-generated mixed waste streams, and (2) polychlorobiphenyls (PCBs) are possible contaminants. Some hazardous constituents found in the current facility wastes were not included in the definition of the generic waste streams. The EPA-defined hazardous characteristic of Reactive/Water-Reactive (D003) was excluded, since it is only associated with the INEL's elemental sodium wastes, which are too reactive to be found in nature. Depending on the media, the hazardous constituents were screened for their logical application to the generic waste streams. For example, the hazardous characteristic of elemental mercury contaminated with radioactive materials (D009) is not applicable to aqueous wastewater streams.

The characterization information for the currently-generated mixed waste streams and generic waste streams at the INEL has been summarized in Table 3. Each row of the Table represents one waste stream, with the columns providing pertinent characterization data derived from the engineering design files. The column headings and the characterization data provided are explained below:

- Waste Stream ID is the INEL-assigned $v$ aste stream identification number, which is used as the EDF serial number. These numbers can be used to reference the EDFs in Appendix B. 
- Radiation Level indicates whether the waste is contact or remote handled.

- Waste Stream Name is a short, descriptive, name for the waste stream. Most names were derived from the WMIS database.

- Waste Stream Description provides a description of the waste media (e.g., soil, sludge, aqueous solution, metals, paper, etc) and the process that generated the waste.

- Annual Volume is the generation rate in cubic meters, predicted by the $g$ nerators.

- $\quad$ EPA Codes is a listing of the hazardous constituents of the waste stream. It lists the EPA code, followed by the appropriate RCRA category and/or subcategory.

- Potential Treatment Strategies is an itemized, condensed, summary of the treatment strategies :dentified for each waste stream. Reference numbers follow each treatment technology (i.e., incineration (TT9000)), which refer the reader to Volume 3, Waste Treatment Technologies, where a description of the technology is provided. The EDFs clarify and further discuss the treatment strategies summarized in this Table.

More detailed information on each waste stream is available in the waste stream EDFs contained in Appendix B.

\subsubsection{Potential Treatment Strategies}

The treatment strategies for mixed waste streams were driven by the RCRA Land Disposal Restrictions (LDR). The LDRs were developed to discourage activities that involve placing untreated wastes in or on the land when a better alternative, such as recycle, reuse, or treatment exists. For each hazardous waste, EPA was required by Congress to establish treatment standards that are protective of human health and the environment when the wastes are land disposed. The treatment standards either (1) require the use of one or more specified treatment technologies, or (2) require that wastes be treated to meet specified concentration limits on the hazardous constituents. These two options are known as technology-based and concentration-based standards, respectively. When concentration-based standards are used, EPA assumes the waste is treated with the Best Demonstrated Available Technology (BDAT). However, the wastes can be treated by any technology as long as the treatment residues do not exceed the concentration limits obtained using the BDAT. 1

The hazardous constituents found in INEL mixed waste streams, and their associated treatment standards, are shown in Table 2. For each constituent, the treatment standards for "wastewater" and "non-wastewater" streams are provided. The term "wastewater" is defined as an aqueous waste with $<1 \%$ total suspended solids (TSS) and $<1 \%$ by weight total organic carbon (TOC). For spent solvent wastes, an additional option is available in which the concentration of solvent constituents can be totaled, and if this total is less than $1 \%$ by weight, the waste is considered to be a wastewater. After determining the category that a waste stream falls into, either "wastewater" or "non-wastewater," the treatment standards of the corresponding column of Table 2 must be followed. Technologybased standards are indicated in the Table by placing the required method of treatment in brackets (i.e., \{Amalgamation\} is a technology-based standard for elemental mercury contaminated with 
radioactive materials). Generally, the residues produced by technology-based treatment are assumed to satisfy the treatment standard. However, concentration-based standards recommend applicable technologies, and specify a concentration for the contaminant which must not be exceeded. This concentration of the hazardous constituent is given as milligrams per liter ( $\mathrm{mg} / \mathrm{L}$ ) total composition in the treated waste stream, or as found in the leachate produced by the Toxicity Characteristic Leaching Procedure (TCLP).

Many INEL mixed waste streams are contaminated with multiple hazardous constituents, and, hence, may have to be treated to meet more than one treatment standard. For wastes that carry more than one characteristic waste code, the waste must be treated to meet the treatment standards for each characteristic. If a RCRA listed waste also exhibits one or more hazardous characteristics, the waste must be treated to meet the treatment standard for both its' listed and characteristic components. If the characteristic standards are specifically addressed by the listed treatment standards, then the standard for the listed waste operates in lieu of the characteristic standard. EPA's general principle is that the more specific treatment standard takes precedence. Treatment standards for listed wastes are the more specific because they reflect the Agency's waste-specific determination.

When possible, waste stream treatment strategies were recommended in accordance with the established treatment standards, and recommendations provided in the EPA treatment technology background documents. Most INEL mixed waste streams are regulated by concentration-based treatment standards. As a minimum, applicable BDATs were recommended for these wastes. When potential for recycle or reuse existed, or in the case of concentration-based treatment standards where other applicable technologies could be used, these options were proposed.

A summary of the proposed potential trcatment alternatives for mixed and generic wastes are presented in Table 3.

\subsection{Low-Level Waste}

Low-level waste (LLW) is defined as waste that contains radioactivity and is not classified as high-level waste, transuranic waste, spent nuclear fuel, or byproduct material. ${ }^{2}$ In this study, lowlevel wastes are distinguished from mixed waste, in that low-level wastes are not contaminated with RCRA-hazardous constituents. As a result, the consideration of treatment alternatives for LLW is simplified, since detailed treatment standards are not imposed by the EPA on these waste streams.

\subsubsection{Identification}

The low-level waste streams were identified by analyzing data from the Radioactive Waste Management Information System (RWMIS), which is a database maintained by Environmental Monitoring, EG\&G Idaho, Inc. RWMIS was developed in 1971 to provide information on the amount of radioactive wastes stored or disposed at the INEL. RWMIS is used by all INEL facilities releasing or generating radioactive waste. RWMIS documents waste shipped from generating facilities to the Waste Experimental Reduction Facility (WERF) for treatment, or to the Radioactive Waste Management Complex (RWMC) for disposal. For the purposes of this study, 3.5 years of RWMIS records (1/1/88 through 6/30/91) were analyzed. This period was selected because (1) the database records use a consistent set of waste descriptions for this time period, and (2) the time period was sufficient to provide an accurate forecast of INEL waste stream trends. 
The future LLW streams were assumed to be similar in composition to the wastes currently generated. The composition of LLW shipments is documented in the RWMIS database by using three-digit alphanumeric content codes (i.e., X21 is any combination of cloth, paper, plastic, and wood), and associated volumes. The composition of each waste shipment container is specified by one or a combination of up to three content codes. In this report, each content code is considered a waste stream. This study assumes that containers using multiple content codes could be physically separated into their respective waste streams. The data for the time period considered were analyzed by summing the portions of each content code listed for all containers and dividing by 3.5 years to get an annual average volume for each waste stream. These averages were compared to the generators' 10-year forecast, which showed some deviations, but a relatively flat trend over the course of the next 10 years. The volume reported for each content code in RWMIS includes significant void space, since waste volume is based on total container volume.

Figure 1 shows the current treatment and disposal practices employed at the INEL. Those wastes that come directly from the generator are considered primary waste streams. The waste is transported from the generator to the WERF for treatment or the RWMC for disposal. There are five destinations for primary waste streams: WERF incineration, WERF compaction, WERF metal sizing, RWMC contact disposal, and RWMC remote disposal. Fifty of the 55 waste streams are primary waste streams. Figure 2 shows the percentage by volume of LLW shipped to each of the five treatment/disposal options. These numbers are calculated as a percentage of the total volume of primary waste streams being processed at the INEL.

Secondary wastes are generated from WERF compaction, WERF incineration, and WERF metalsizing operations. The fjve content codes developed to track secondary waste streams, which are disposed of at the RWMC, are A34 (Ash Solidified in Concrete), M71 (Metal Sized by WERF Carbon Steel), M73 (Metal Sized by WERF - Nonferrous), M72 (Metal Sized by WERF - Stainless Steel), and A.31 (Ash, Unsolidified).

An EDF was generated for each waste stream to document characterization data and potential treatment strategies. For 7 of the 55 waste streams, treatment strategies were not identified, because 5 secondary waste streams do not require treatment, one is no longer generated, and one had insufficient data available to recommend treatment strategies. Table 4 summarizes the 55 low-level waste streams, which are listed by volume from highest to lowest annual generation rate in cubic meters per year.

\subsubsection{Characterization}

Characterization information was derived from the RWMIS database. The low-level waste streams were characterized in order to identify potential treatment strategies. Specific data that were obtained consisted of waste stream description; annual generation rate; annual volumes treated by incineration, compaction, and metal-sizing at WERF; volumes shipped to the RWMC for disposal; the curie content per cubic meter of waste; the radiation dose rate at $3 \mathrm{ft}$ from the shipping container; and facilities contributing to the waste stream. This information is summarized in Table 4. The column headings, and the characterization data are explained below: 


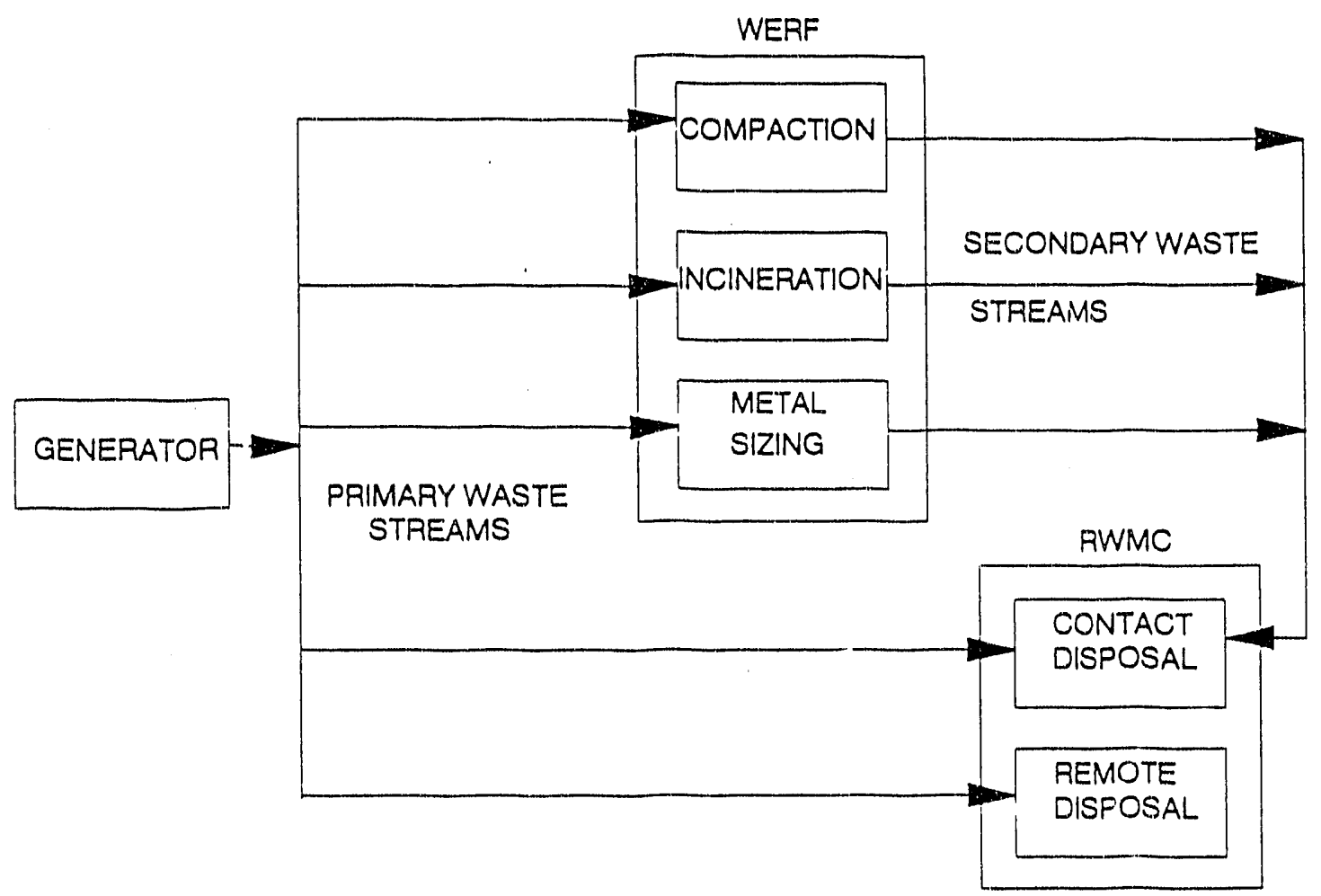

Figure 1. Current low-level waste treatment practices.

\section{Low Level Waste Destinations}

(\% by volume)

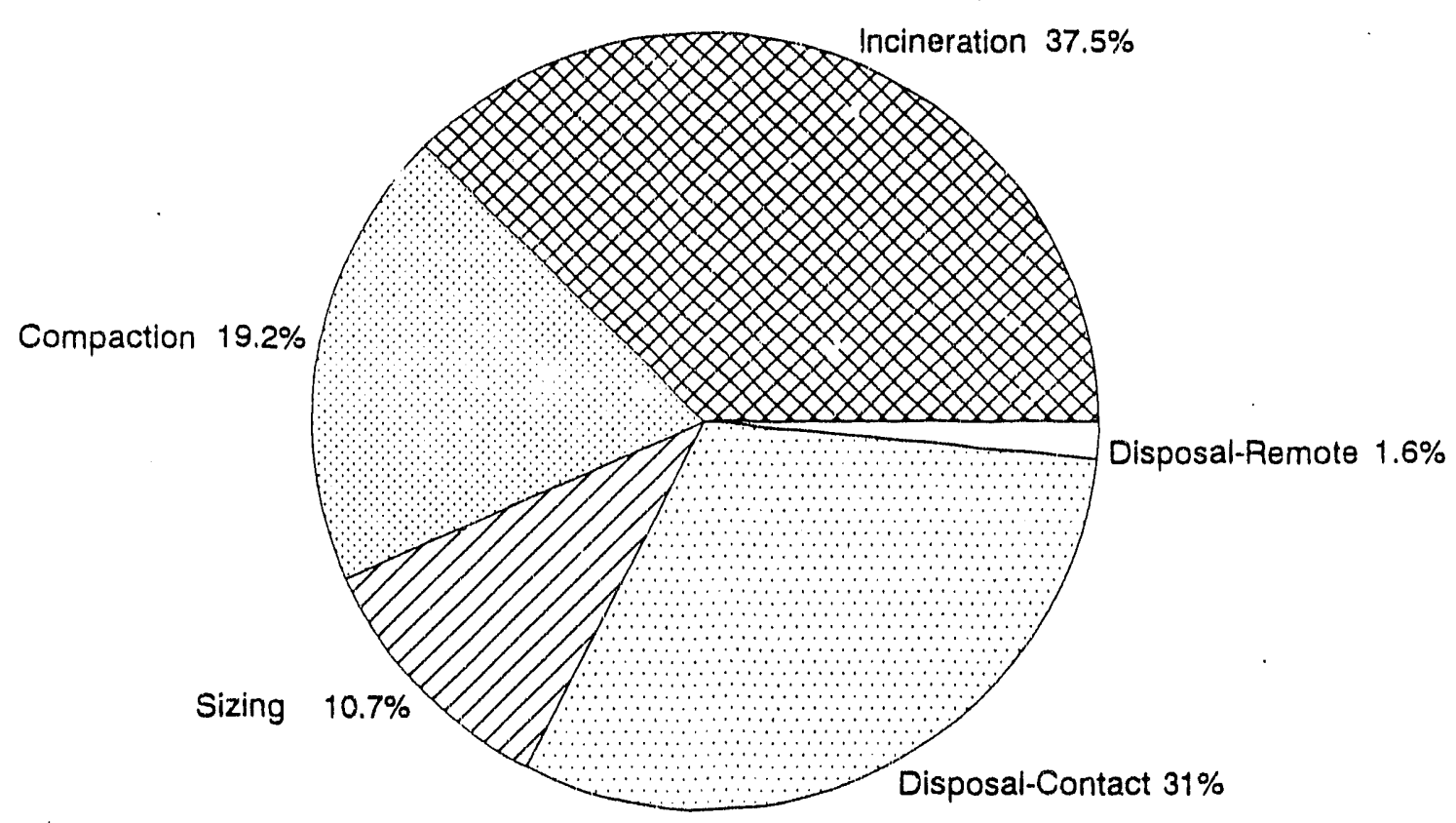

Figure 2. Low-level waste destinations. 
- Waste Stream ID is the content code used by the RWMIS database to describe the contents of a shipment. In this study, each content code is a waste stream. Also, the content code is used as the waste stream EDF serial number.

- Waste Stream Description is a short description of the waste streain. These descriptions were derived from the RWMIS database.

- Annual Volume is the estimated annual generation rate.

- Current Practice is a listing of the current treatment and disposal options used to manage each waste stream. Five treatment and disposal options are available: incineration, compaction, sizing, disposal-contact, and disposal remote. For each option used, the percent of tota, waste stream volume processed by that option is shown.

- Annual Curies is the average number of curies shipped per year.

- Low, High, and Average Dose Rate columns provide dose rate data, measured at the container level. The measurements are given in units of $\mathrm{mR} / \mathrm{hr}$ (milliroentgen/hour).

- Potential Treatment Strategies is an liemized, condensed, summary of the treatment strategies identified for each waste stream. Reference numbers follow each treatment technology [(i.e., incineration (TT9000)], which refer the reader to Volume 3, Waste Treatment Technologies, where a description of the technology is provided. The EDFs clarify and further discuss the treatment strategies summarized in this Table.

More detailed characterization information can be found in the EDFs in Appendix B.

\subsubsection{Potential Treatment Strategies}

The philosophy used to determine treatment strategies for low-level waste are derived from DOE Order $5820.2 \mathrm{~A}$, which recommends volume reduction to increase disposal facility life and stabilization to reduce the mobility of radionuclides present in the waste.

Considering the volume reduction and stabilization objectives for LLW, potential waste stream treatment strategies were proposed by a review committee having knowledge aboust radioactive waste treatment.

The treatment strategies identified for each waste stream are summarized in Table 4. 


\section{SUMMARY AND OBSERVATIONS}

This section provides some global observations made during the waste stream studies, and summarizes significant INEL waste stream characteristics.

\subsection{Mixed Waste}

This study addressed 37 INEL mixed-waste streams predicted by the generators, and 6 generic waste streams identified to address chemical spills and secondary waste streams expected to be produced by environmental restoration activities. Currently, INEL mixed-waste streams are placed in storage, awaiting treatment capability. As a result, no summaries are available about current treatment capability. This section will summarize some waste stream characteristics of interest, such as RCRA categories, radiation levels, physical forms, combuscible categories, and hazardous constituents. Also, some general comments concerning the identification of potential treatment strategies are presented.

Table 1 shows the RCRA hazardo: is waste constituents found in the INEL's mixed-waste streams. The volume percent of INEL mixed wastes that fall into the RCRA categories of characteristic and listed hazardous waste are shown in Figure 3. Most of the mixed wastes generated at the INEL (98.3\%) are RCRA characteristic wastes (ignitable, corrosive, reactive, or toxic). These wastes are assigned the EPA hazardous waste codes of D001 through D035. Under RCRA regulations, these wastes are not considered hazardous after treatment if they no longer exhibit the characteristic of ignitability, corrosivity, reactivity. or toxicity. This means that $98.3 \%$ of the total mixed-waste volume generated at the INEL may be disposed of as a radioactive waste after treatment.

$58.4 \%$ of the mixed waste volume, as shown in Figure 4 , has been identified as contact-handled waste. Only $0.3 \%$ of the waste has been identified as remote-handled. The remaining $41.3 \%$ of the mixed-waste streams were not identified by radiation level in the WMIS database. This information is necessary in order to ensure that the correct precautions are taken when handling the wastes.

The physical form of the wastes were reported in WMIS as either solid, liquid, or sludge/slurry. As illustrated in Figure 5, 94.6\% of the mixed-waste streams are solid, and 5.4\% are liquid. The high proportion of solids in the mixed-waste streams indicates a need for solids handling capability.

The mixed waste streams were also classified according to their combustibility. They are listed as either combustible, noncombustible, or mixed. The mixed combustible category means the waste stream is composed of at least $10 \%$ by volume combustible waste or at most $90 \%$ by volume combustible waste. As shown in Figure $6,86.5 \%$ by volume of the mixed-waste streams are noncombustible, $6.2 \%$ are combustible, and the remaining $7.3 \%$ is mixed combustible and noncombustible wastes. For a number of the mixed and noncombustible waste strearns, incineration was recommended to satisfy the treatment standards. Often, the intent of this treatment strategy was to put the waste in a consistent form suitable for stabilization. After incineration, the noncombustible portion of the waste is then stabilized or vitrified with the incinerator ash and off-gas system residues, or removed for recycle. 
Table 1. Hazardous constituents found in INEL mixed waste streams.

\begin{tabular}{|c|c|c|}
\hline EPA code & RCRA category & RCRA sub-category \\
\hline D001 & Ignitable & $1 \%<\mathrm{TOC}<10 \%$ \\
\hline D001 & Ignitable & $<1 \%$ TOC, $<1 \%$ TSS, wastewater \\
\hline Do02 & Corrosive & Other corrosive \\
\hline $\mathrm{D} 003$ & Reactive & Water reactive \\
\hline D004 & Toxic & Arsenic \\
\hline D005 & Toxic & Barium \\
\hline D006 & Toxic & Cadmium \\
\hline D007 & Toxic & Chromium \\
\hline D008 & Toxic & Radioactive lead solids \\
\hline D008 & Toxic & Lead acid batteries \\
\hline D009 & Toxic & High mercury $>=260 \mathrm{mg} / \mathrm{kg}$ total mercury \\
\hline D009 & Toxic & $\begin{array}{l}\text { Elemental mercury contaminated with } \\
\text { radioactive materials }\end{array}$ \\
\hline D010 & Toxic & Selenium \\
\hline D011 & Toxic & Silver \\
\hline D035 & Listed & Methyl ethyl ketone \\
\hline F001 & Listed & $\begin{array}{l}\text { 1,1,1-Trichloroethane: spent halogenated } \\
\text { solvents }\end{array}$ \\
\hline $\mathrm{FOO} 2$ & Listed & $\begin{array}{l}\text { Trichloroethylene: spent halogenated } \\
\text { solvents }\end{array}$ \\
\hline F002 & Listed & $\begin{array}{l}\text { Methylene chloride: spent halogenated } \\
\text { solvents }\end{array}$ \\
\hline F003 & Listed & Acetone: spent nonhalogenated solvents \\
\hline F003 & Listed & Methanol: spent nonhalogenated solvents \\
\hline $\mathrm{F} 003$ & Listed & Xylene: spent nonhalogenated solvents \\
\hline FOO4 & Listed & Creosols: spent nonhalogenated solvents \\
\hline F005 & Listed & Toluene: spent nonhalogenated solvents \\
\hline U134 & Listed & Hydrofluoric acid \\
\hline
\end{tabular}




\section{Mixed Waste RCRA Categorles}

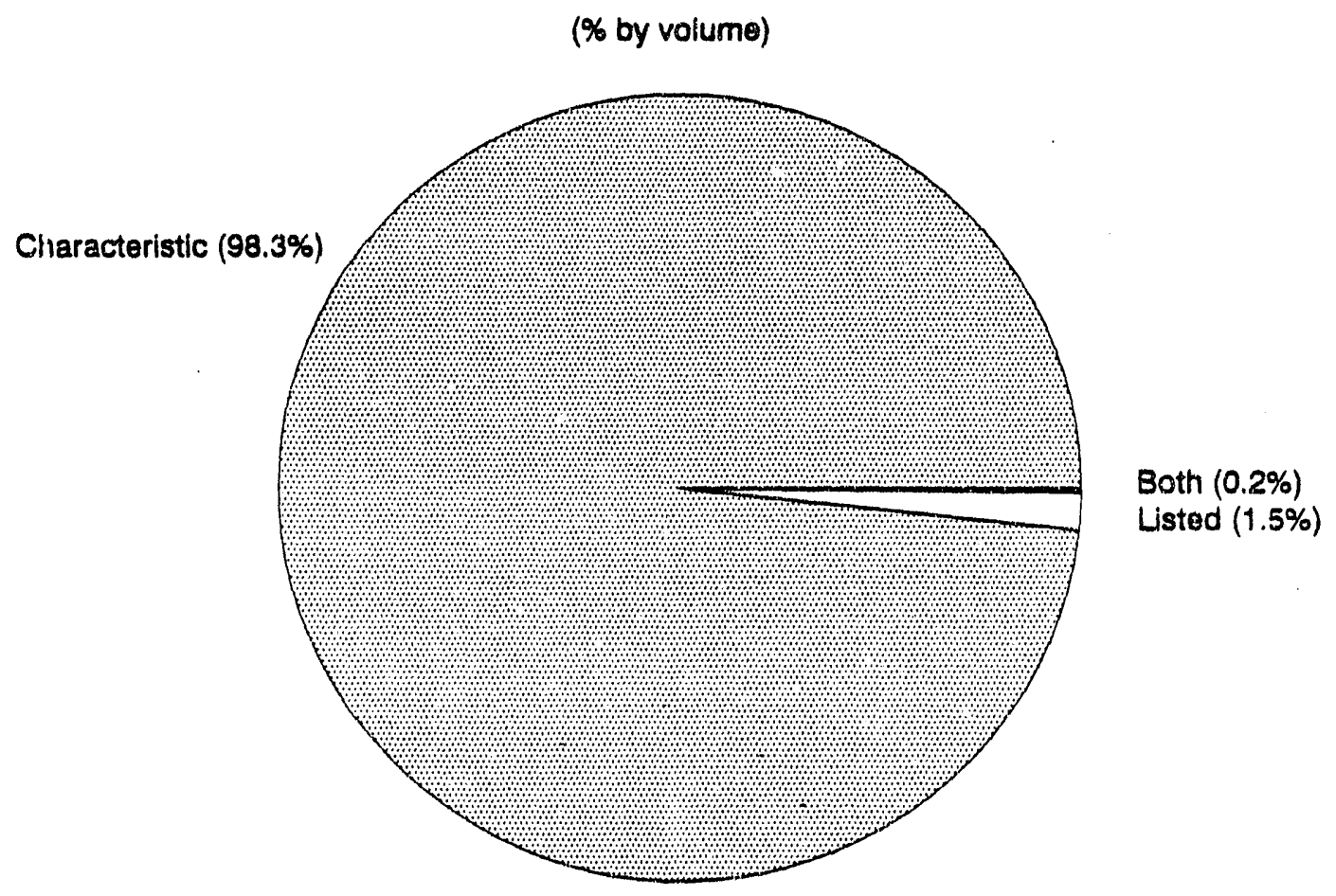

Figure 3. RCRA categories of mixed wastes at the INEL.

Mixed Waste Radiation Levels

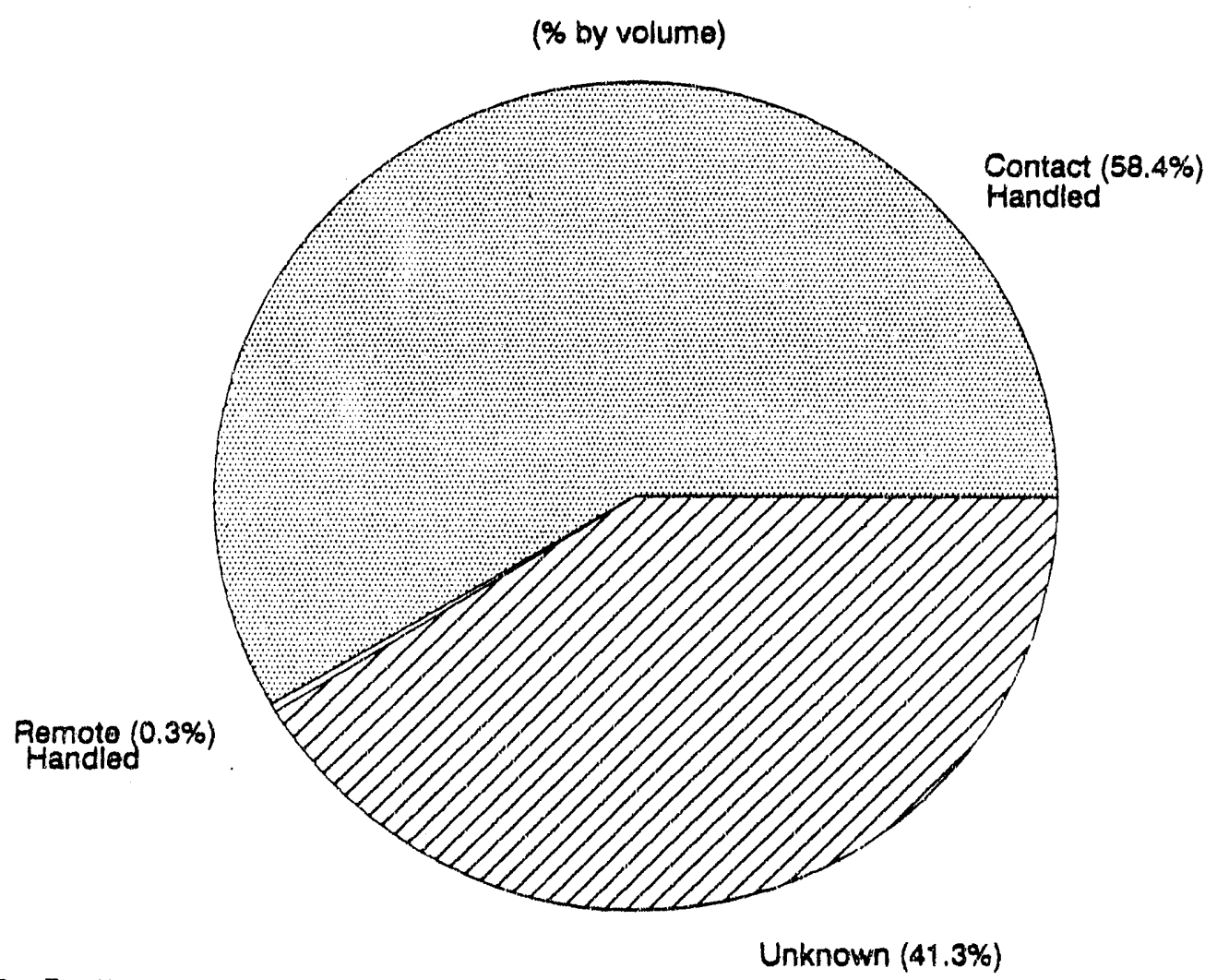

Figure 4. Padiation levels for handling of mived wastes at the INEL. 


\section{Mixed Wastes Physical Form}

(\% by volume)

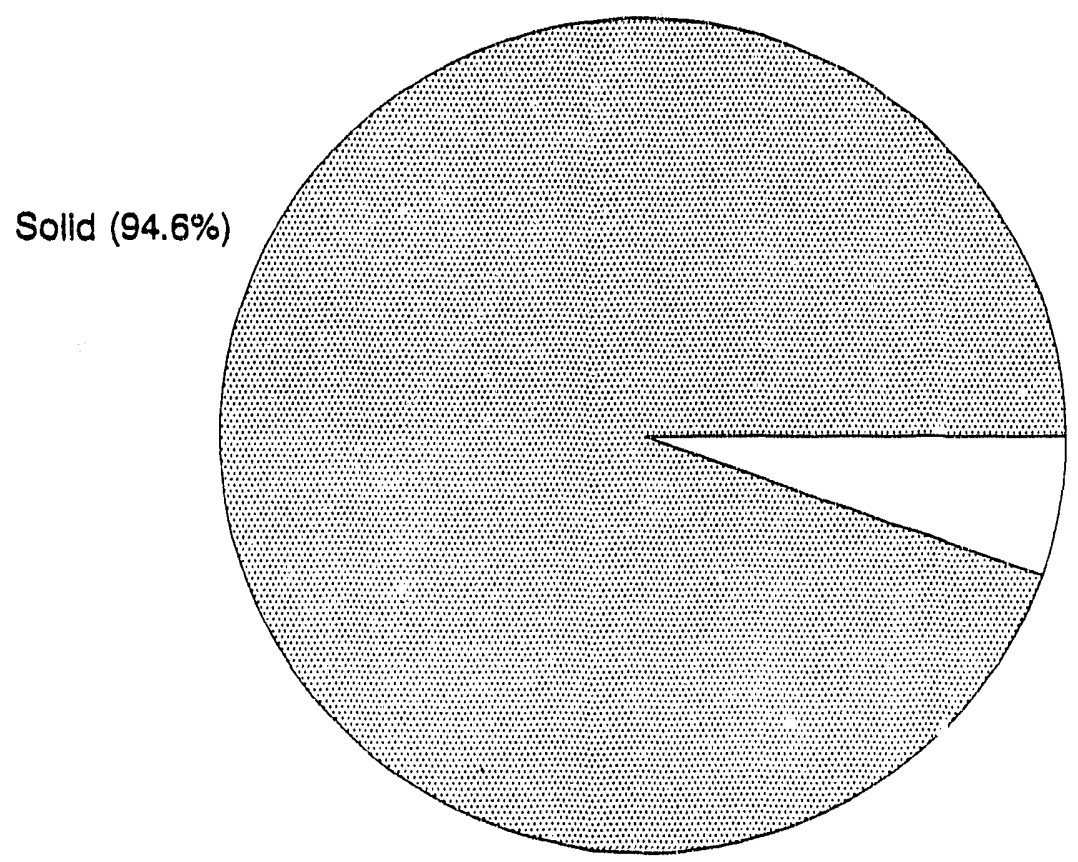

Liquild $(5.4 \%)$

Figure 5. Physical form of mixed wastes at the INEL.

\section{Mixed Waste Combustible Categories}

(\% by volume)

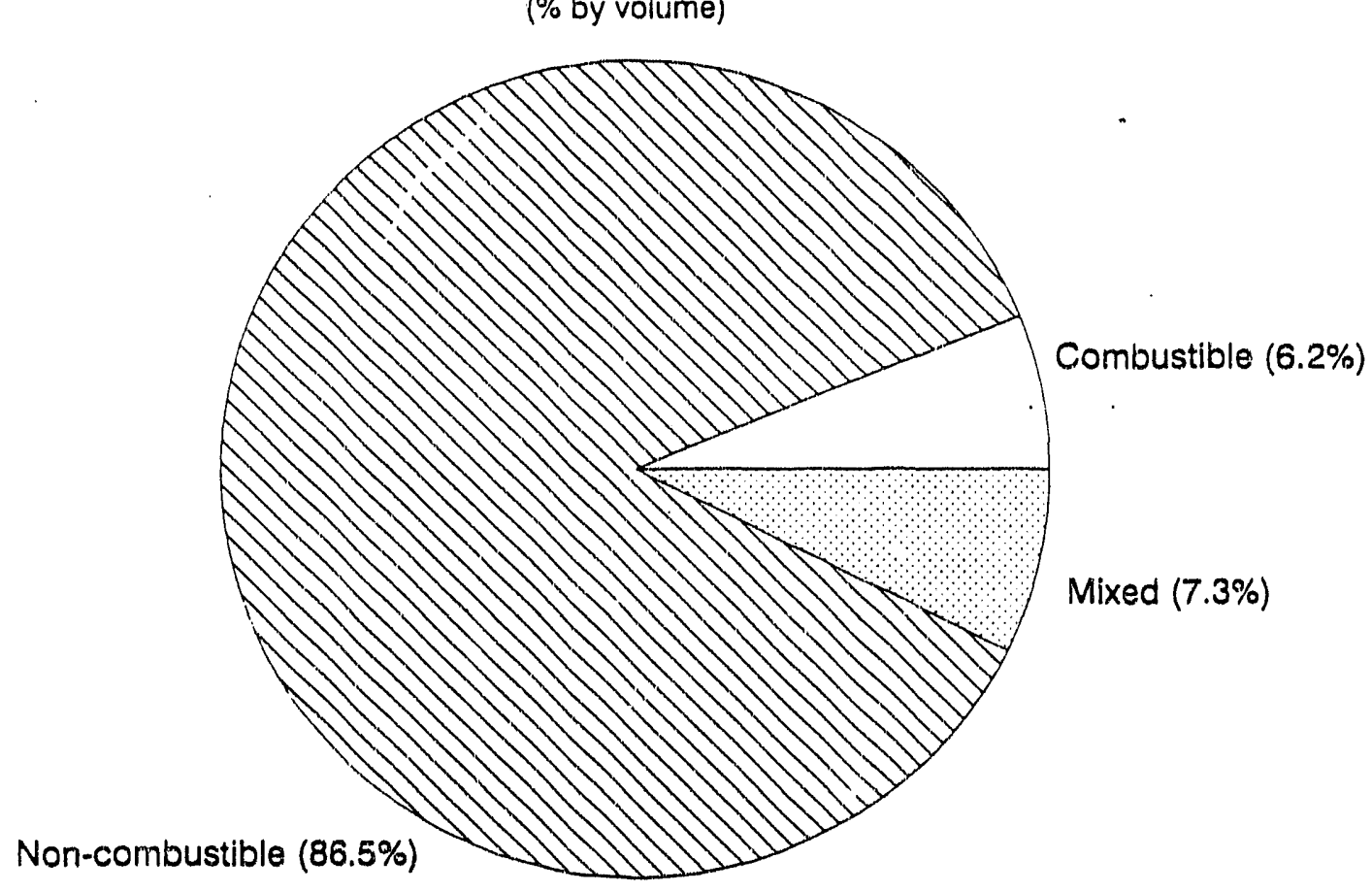

Figure 6. Combustible categories of mixed waste at the INEL. 
Some comments concerning the identification of waste stream treatment strategies are stated below:

- The treatment standard for radioactive lead solids is macroencapsulation. However, since large volumes of lead are used as shielding at the INEL, lead recycling and reuse were considered appropriate options. Recycled INEL lead will probably never be considered sufficiently "clean" by commercial industry, but its use within. DOE facilities is recommended. ${ }^{3}$

- No biological treatment systems were proposed for the waste streams. Biological treatment systems requires a relatively steady feed rate to be effective. All waste streams are generated on a sporadic basis, making this option infeasible.

\subsection{Low-Level Waste}

Fifty-five LLW steams were addressed by this study. Currently, these wastes undergo treatment at WERF, or disposal at RWMC. The current treatment and disposal status of the INEL LLW streams are summarized in Figures 1 and 2 of Section 2.2.1. This section summarizes some waste stream characteristics, such as high-volume waste streams, waste bypassing treatment, combustible categories, and radiation levels.

Figure 7 shows the 10 highest-volume INEL. LLIV streams, identified by their content codes. Ten of the original 55 waste streams constitute nearly $90 \%$ of the total volume. This implies that treatment capability focused on as few as ten waste streams could address the majority of the INEL's LLW volume. Descriptions for the content codes used in Figure 7 are as follows:

X21 Any combination of cloth, paper, plastic, and wood

X41 Any combination of glass, halogenated plastic, lagging, liquid absorbents, metal chips, wire, etc

M41 Metal combination assemblies

P21 Paper and/or cloth

S71 Soil/gravel/brick/concrete rubble

M31 metal-steel, carbon

M33 Metal-steel, stainless

R50 HFEF. South facility modification waste stream

X80 NRF/ECF/WER only-mix. std. CC M31-20\%, M33-30\%, M41-10\%, X41-40\%

X22 NRF/ECF Only-Mix. Std. CC P21-60\%, P41-30\%, W31-10\%.

Figures 8 and 9 reveal an important factor about low-level wastes currently being treated at the INEL. Approximately $68 \%$ of the wastes by volume are being treated. However, this volume only represents $0.0033 \%$ of the total curie content of low-level wastes generated at the INEL. This means that $99.9967 \%$ of the curie content is shipped without treatment to the RWMC for burial.

Figure 10 reveals that almost half of the low-level wastes at the INEL are combustible and can be treated by incineration. In some cases, the mixed combustible wastes can be incinerated and the non-combustible portions stabilized with the ash and off-gas system residues, or recovered for recycle or further treatment. 


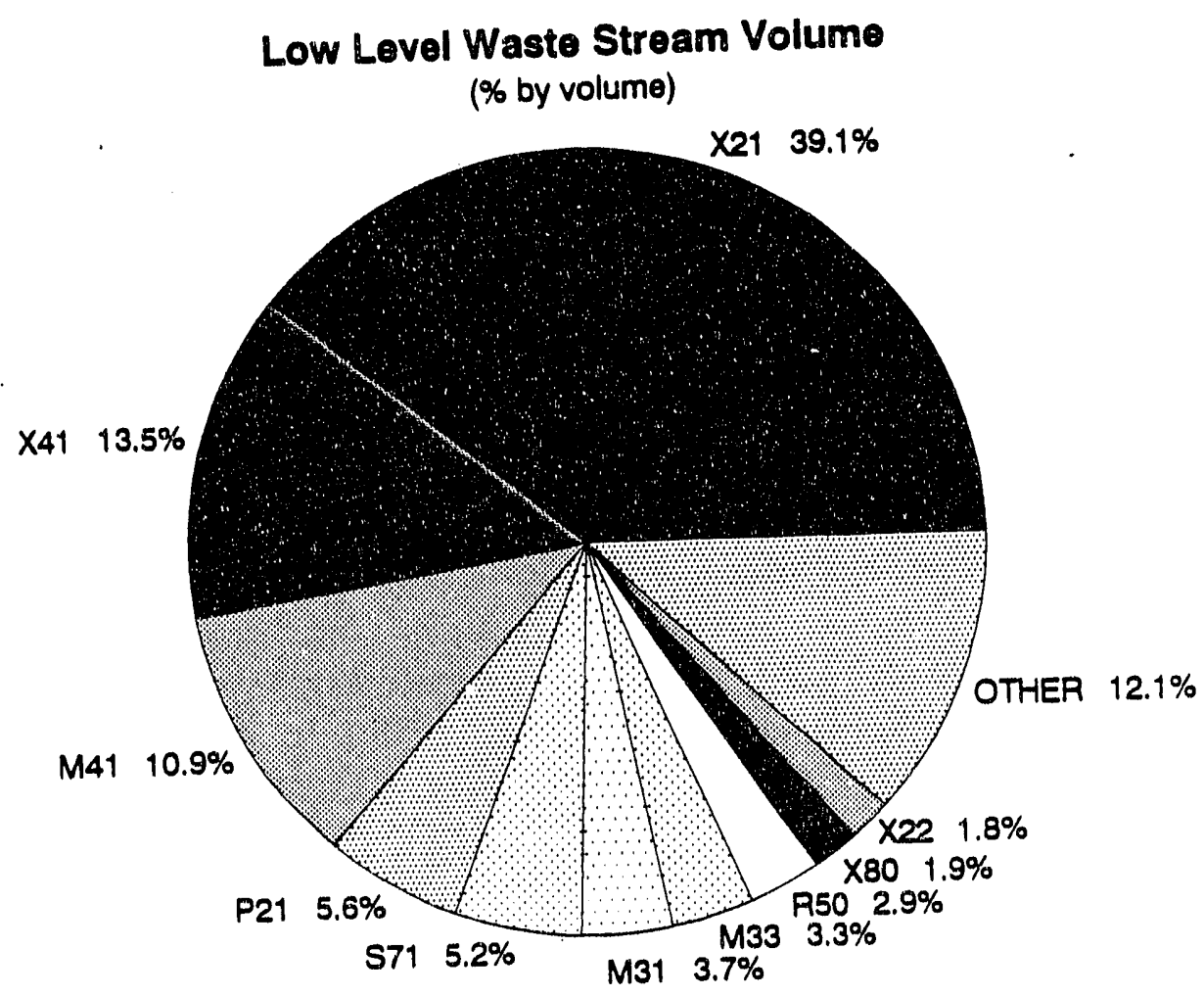

Figure 7. Distribution of the 10 highest volume low-level waste streams, by percent volume.

\section{LLW Waste Treatment Status}

(\% by volume)

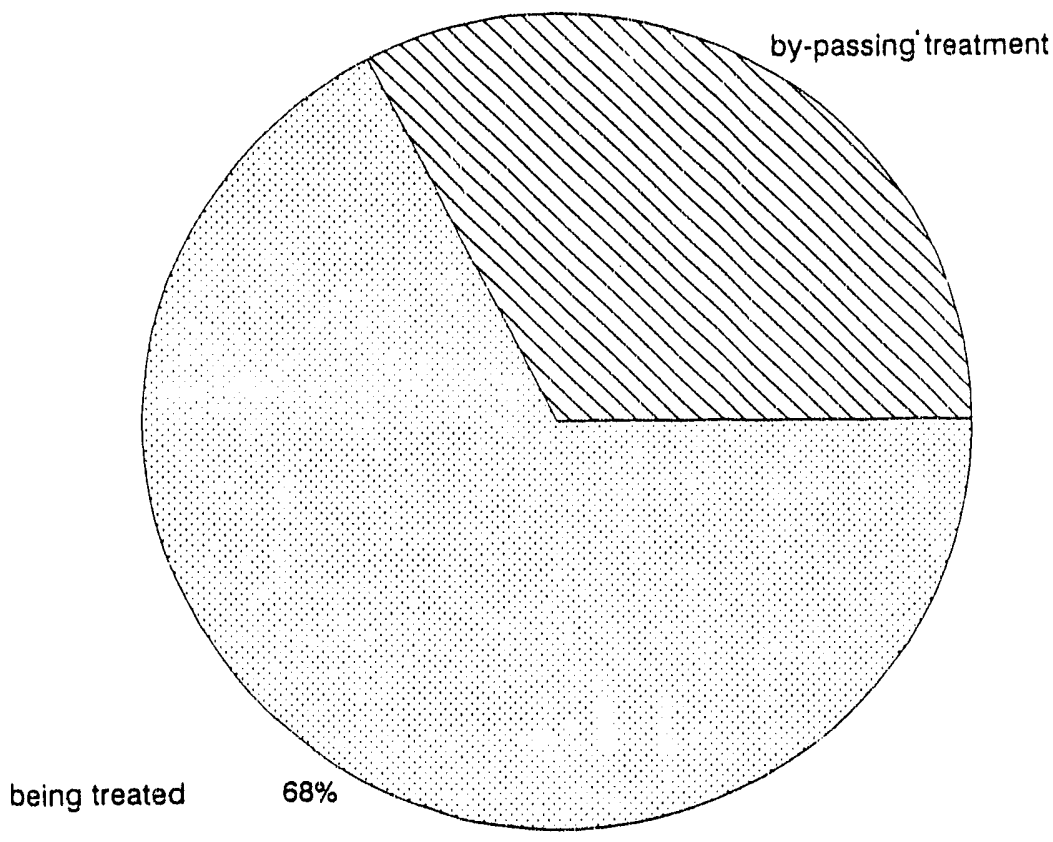

$32 \%$

Figure 8. Luw-ievel waste bypassing treatment at the INEL, by percent volume. 


\section{LLW Waste Treatment Status}

(\% by curie content)

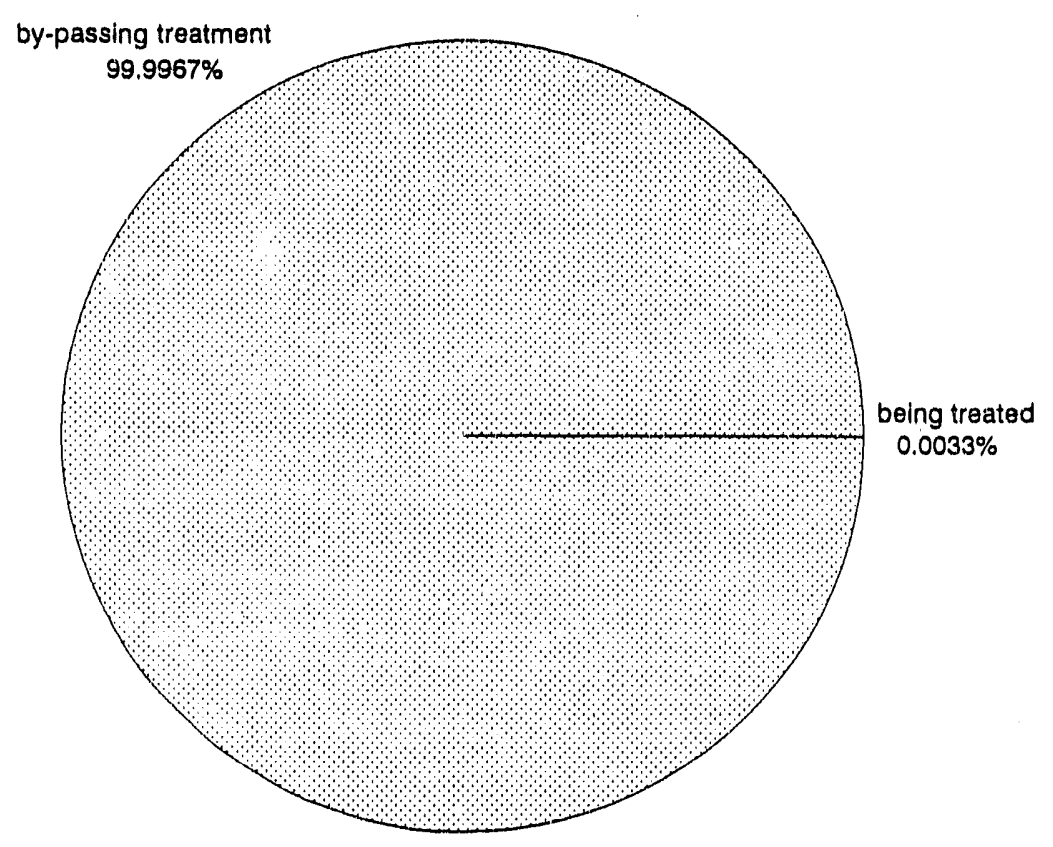

Figure 9. Low-level waste bypassing treatment at the INEL, by percent curie content.

\section{LLW Combustible Categories}

( $\%$ by volume)

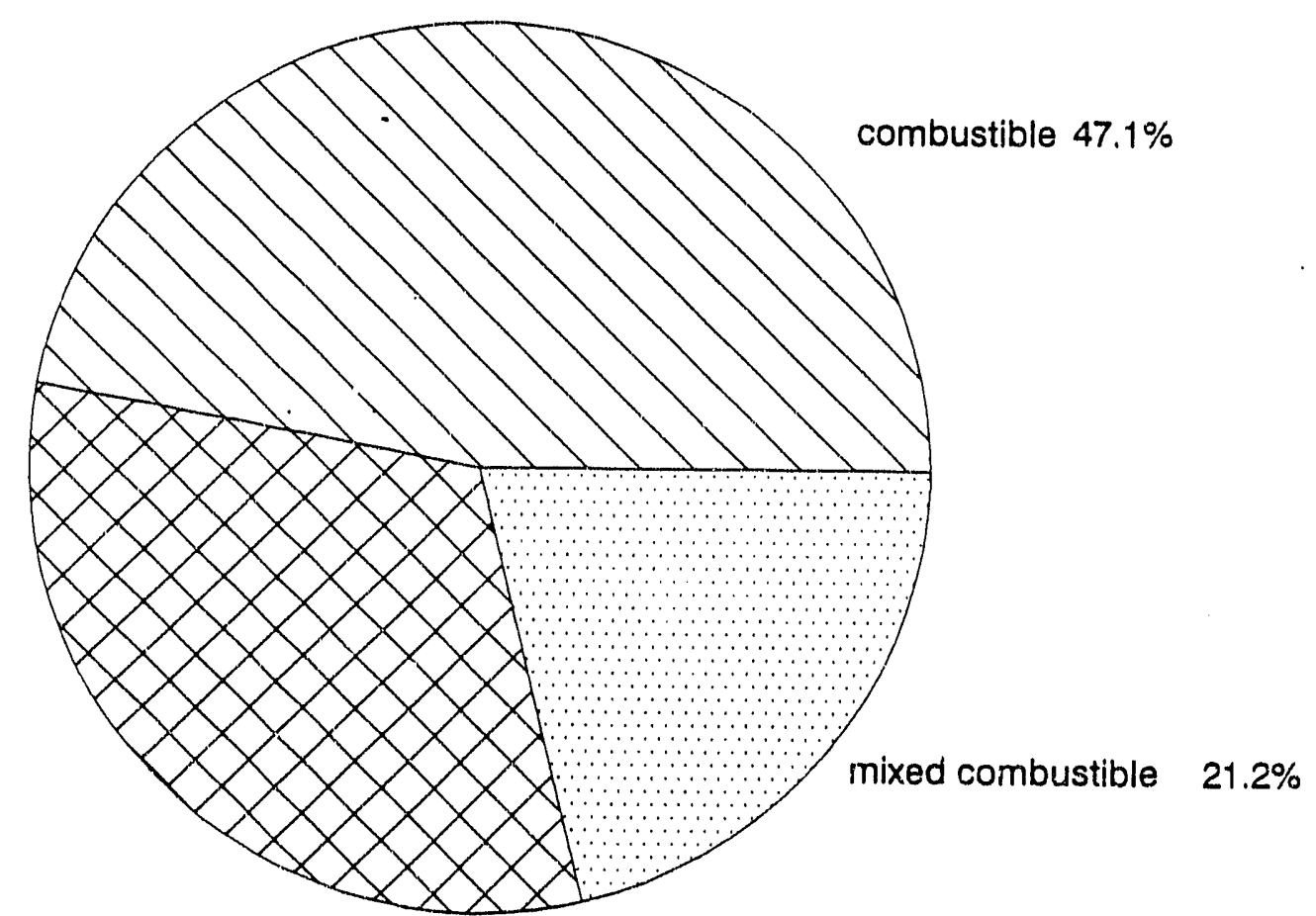

non-combustible $\quad 31.7 \%$

Figure 10. Combustible categories of low-level waste at the INEL. 
Figure 11 shows that nearly all of the INEL's LLW is contact handled, with only $1.6 \%$ requiring remote handling capability.

Some comments concerning the identification of waste stream treatment strategies are stated below:

- Waste stream S83, Source Alpha, had no potential treatment strategy identified because insufficient characterization data were found. It is the smallest volume waste stream, with only one shipment occurring during the 3.5 years of RWMIS records that were analyzed.

- For some waste streams, the only treatment strategy recommended is packaging if necessary, followed by disposal. These waste streams are as follows:

S72 Concrete structural components

I22 Ion exchange resin in concrete containment

E21 Evaporation drum (e.g., shade)

- In many cases, vitrification technologies, which are relatively expensive, can be substituted for stabilization technologies (e.g., portland cement, lime/fly ash, etc). Often, when stabilization technologies are proposed, vitrification would have also been acceptable.

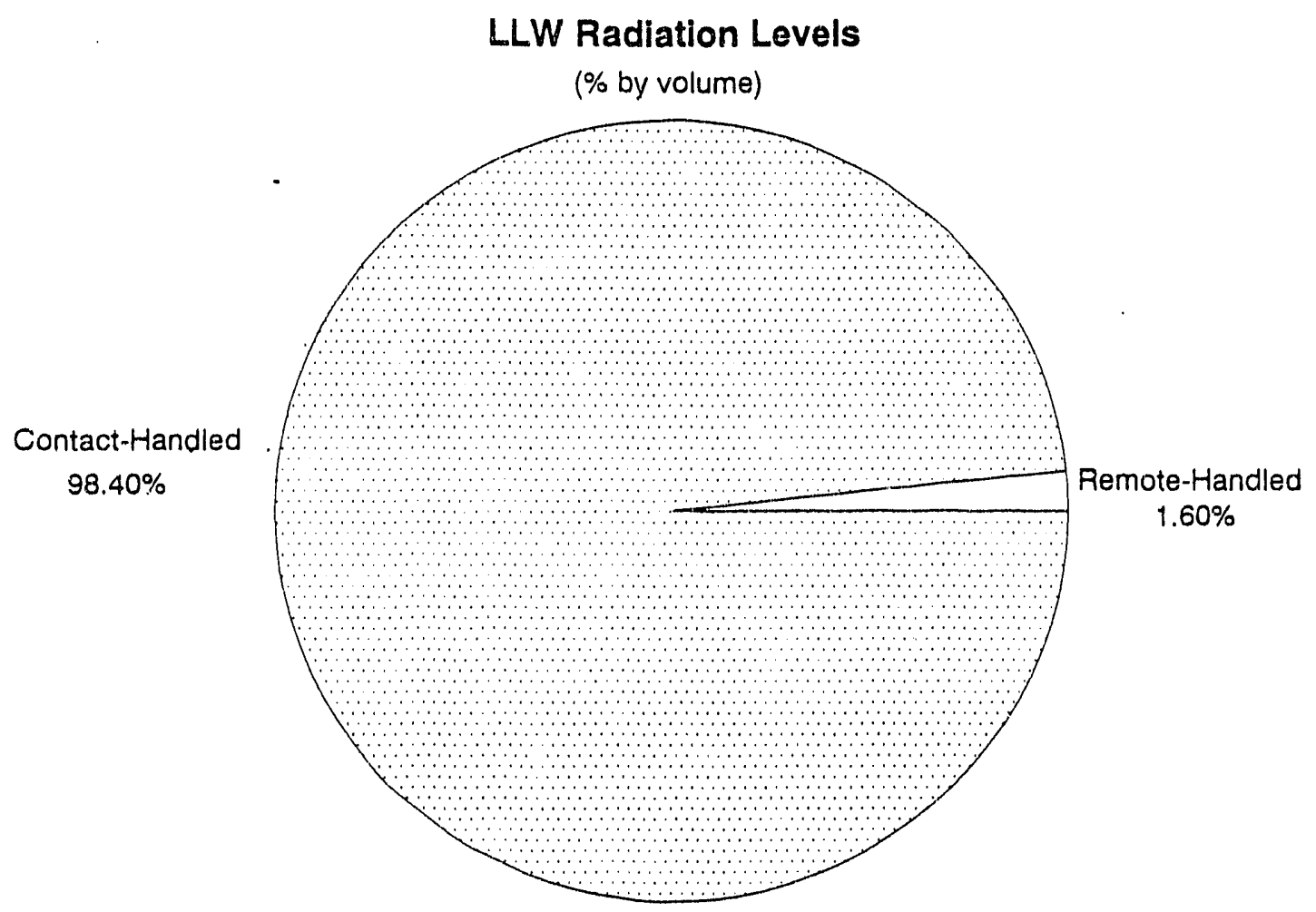

Figure 11. Radiation levels for handling of low-level waste. 


\subsection{Summary}

The treatments recommended by this preengineering study are intended to provide a starting point for system design studies and conceptual design. Volume 3, Waste Treatment Technologies contains descriptions of the recommended treatment technologies. Appendix B, Waste Stream Engineering Files, contains more specific characterization information and a detailed rationale for recommended treatments for each waste stream. The summary tables for mixed and low-level waste stream data referenced in this volume follow. 


\section{REFERENCES}

1. McCoy and Associates, The RCRA Land Disposal Restrictions: A Guide to Compliance, 1991 Edition, Lakewood, Colorado.

2. U:S. DOE, Radioactive Waste Management, DOE 5820.2A, September 26, 1988.

3. L. Rosengrant, Monica Chatmon-McEaddy, Final Best Demonstrated Available Technology (BDAT) Background Docuntent for D008 and P and U Lead Wastes, USEPA, 530-SW-90-059W (NTS: PB90-234238), May 1990. 


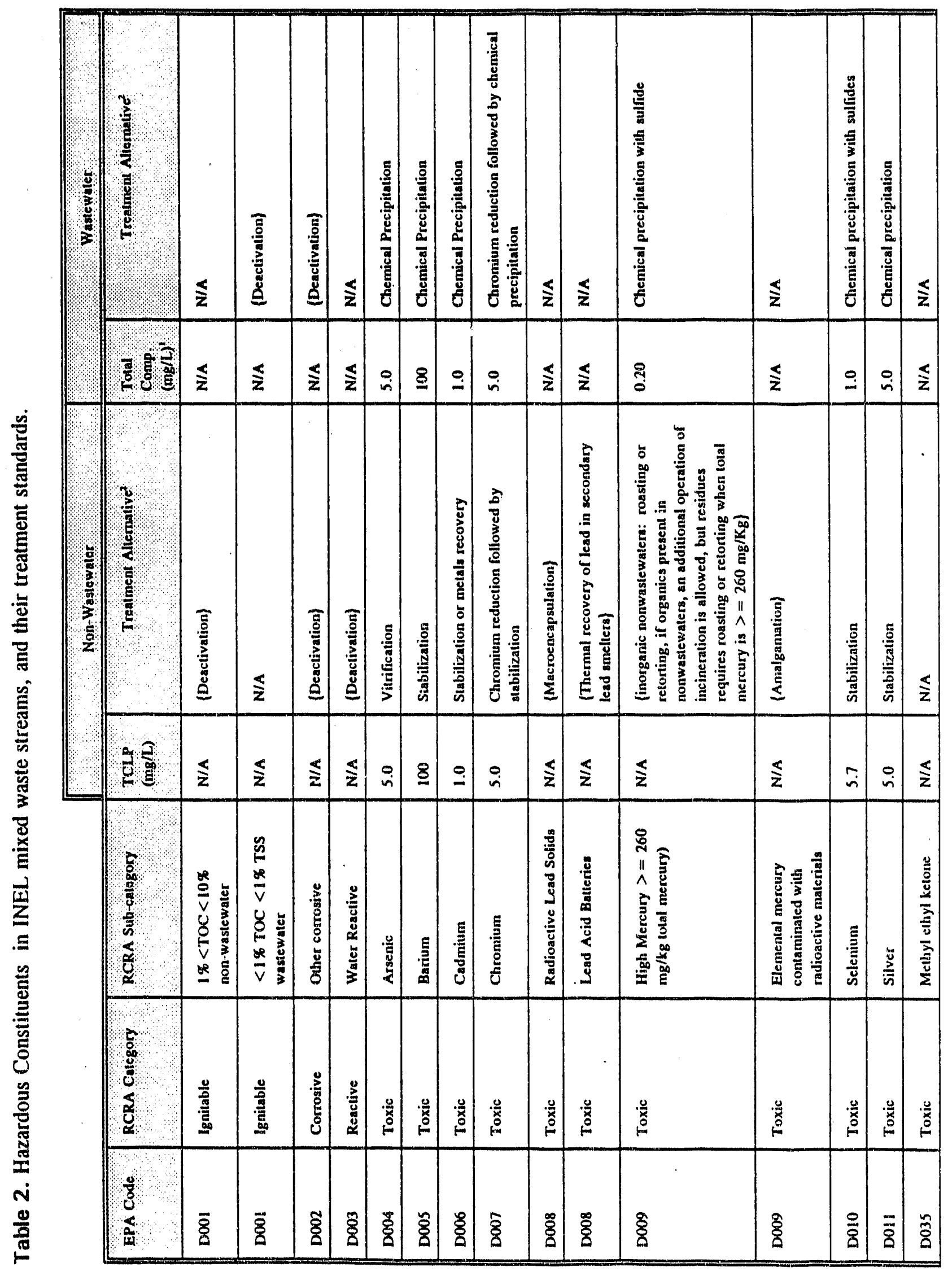




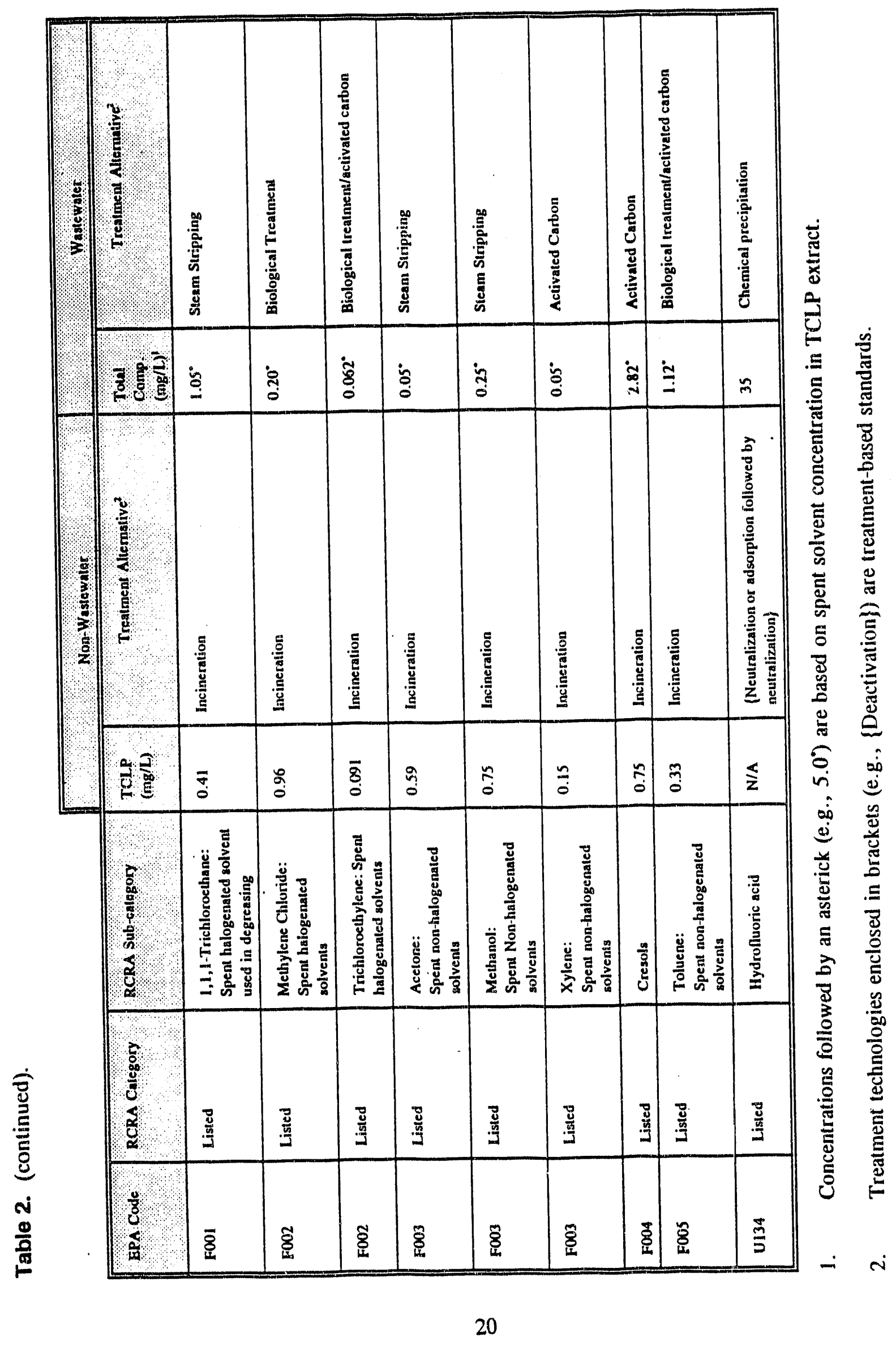


Table 3. Summary of Mixed Waste Stream Identification, Characterization and Treatme

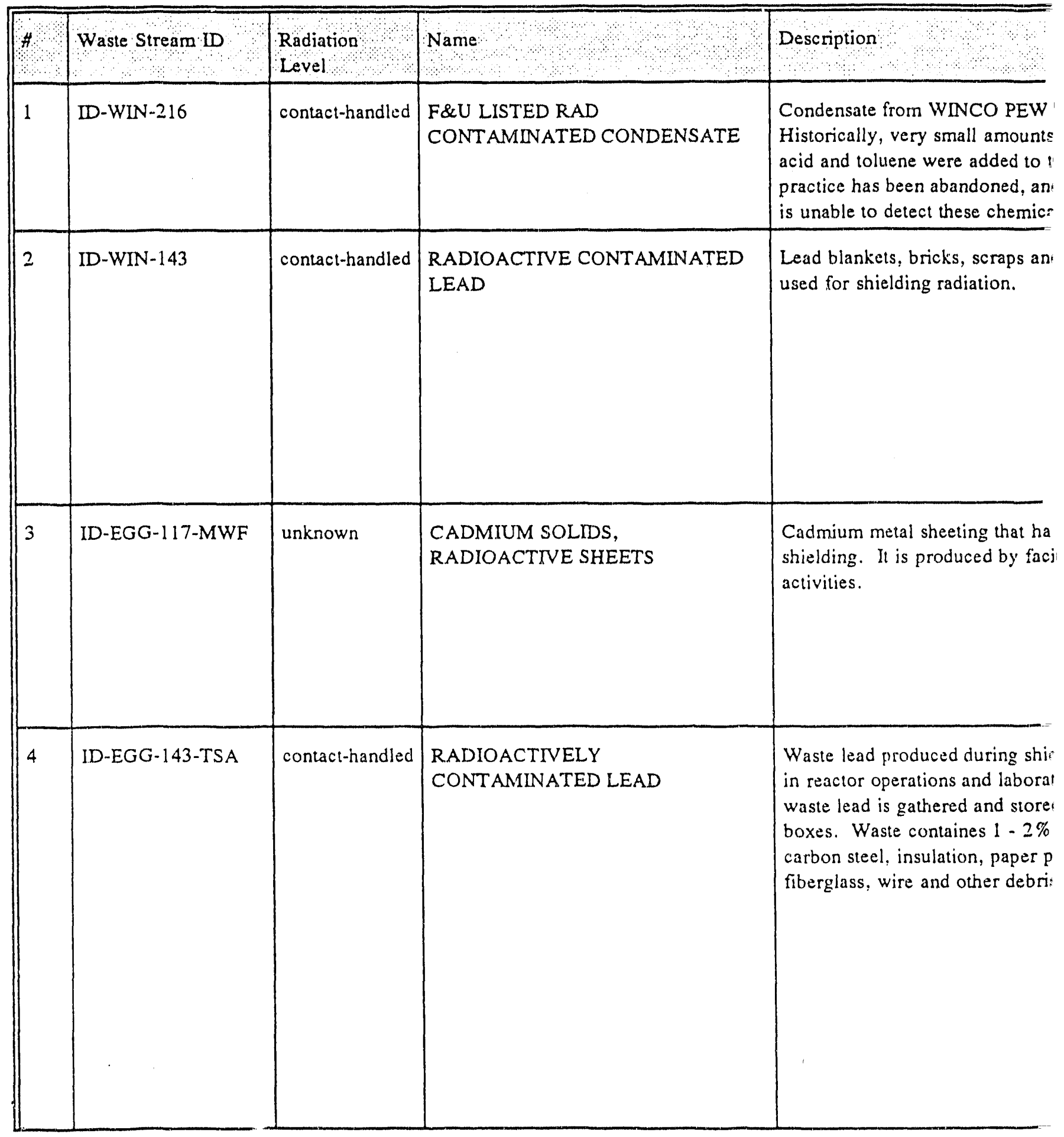


tt Strategies.

\begin{tabular}{|c|c|c|c|}
\hline & $\begin{array}{l}\text { Annual } \\
\text { Volume }\end{array}$ & EPA Codes & $\begin{array}{l}\text { Potential Treatment Strategies } \\
(f b=\text { followed by },<>=\text { if necessary) }\end{array}$ \\
\hline $\begin{array}{l}\text { evaporator. } \\
\text { of hydrofluoric } \\
\text { system. This } \\
\text { current analysis } \\
\text { s. }\end{array}$ & $11060.00 \mathrm{~m}^{3}$ & $\begin{array}{l}\text { F005 Toluene-> spent non- } \\
\text { halogenated solvents } \\
\text { U134 Hydrofluoric Acid }\end{array}$ & - Waste will be treated by the generatios. \\
\hline sheets that were & $25.20 \mathrm{~m}^{3}$ & D008 Radioactive lead solids & $\begin{array}{l}\text { Separate non-lead scrap metal for volume reduction } \\
\text { (TT8000), refine the lead using high-temperature melats } \\
\text { recovery (TT1500()) } f b \text { off-gas treatment (TT23000) and } \\
\text { stabilization (TT12000) of slag and off-gas system } \\
\text { residues. } \\
\text { Decontamination (TT2000) of the lead for reuse by } \\
\text { removal of the outer contaminated layer } f b \text { stabilization } \\
\text { (TT12000) of the resulting residues. } \\
\text { < volume reduition > (TT8000) of the lead wastes } f b \\
\text { macroencapsulation (TT12900). }\end{array}$ \\
\hline $\begin{array}{l}\text { been used for } \\
\text { ity } D \& D\end{array}$ & $10.00 \mathrm{~m}^{3}$ & Do06 Cadmium & $\begin{array}{l}\text { Macroencapsulation (TT12900). } \\
\text { Decontamination (TT2000) of the cadmium for reuse by } \\
\text { removal of the outer contaminaied layer } f b \\
\text { <neutralization > and < precipitation > } f b \text { stabilization } \\
\text { (TT12000) of the secondary waste streams. } \\
\text { Recycle cadmium using high temperature metals recovery } \\
\text { (TT15000) } f b \text { stabilization (TT } 2000 \text { ) of the slag and } \\
\text { secondary waste streams. }\end{array}$ \\
\hline $\begin{array}{l}\text { ding operations } \\
\text { ry use. The } \\
\text { in wooden } \\
\text { of cast iron. } \\
\text { oducts. }\end{array}$ & $9.54 \mathrm{~m}^{3}$ & D008 Radioactive lead solids & $\begin{array}{l}\text { Separate non-lead scrap metal for volume reduction } \\
\text { (TT8000), refine the lead using high-tempezature metals } \\
\text { recovery (TT15000) fb off-gas treatment (TT23000) and } \\
\text { stabilization (IT12000) of slag and cff-gas system } \\
\text { residues. } \\
\text { - Decontamination (TT2000) of the lead for reuse by } \\
\text { removal of thi outer contaminated layer } f b \text { stabilization } \\
\text { (TT12000) of the resulting residues. } \\
\text { < volume reduction> (TT8000) of the lead wastes, fo } \\
\text { masroencapsulation (TT12900). } \\
\text { Separate scrap lead pieces from other combustible waste } \\
\text { and send to lead treatment (one of the } 3 \text { options above). } \\
\text { <size> (TT14000) the remainirg waste for incineration } \\
\text { (TT9000) fo stabilization (TT12000) of the ash and off- } \\
\text { gas system residues. }\end{array}$ \\
\hline
\end{tabular}


Table 3. (continued).

\begin{tabular}{|c|c|c|c|c|}
\hline$\#$ & Waste Stream ID & $\begin{array}{l}\text { Radiation } \\
\text { Level }\end{array}$ & Name & Description \\
\hline 5 & ID-SMC-135 & contact-handled & NONACIDIC WASTE LIQUID & $\begin{array}{l}\text { Various wastewater streams produ } \\
\text { SMC facility. The wastewater rus } \\
\text { tank where the liquid is then prock } \\
\text { drum evaporator. }\end{array}$ \\
\hline 6 & ID-EGG-157 & unknown & $\begin{array}{l}\text { TRA WARM WASTE POND } \\
\text { SLUDGE }\end{array}$ & $\begin{array}{l}\text { Environmental restoration samples } \\
\text { Warm Waste Pond Sludge. It is } \\
\text { noncombustible solid sludge conta } \\
\text { cadmium, chromium. lead, mercu } \\
\text { cyanides, and sulfides. }\end{array}$ \\
\hline 7 & ID-SMC.136 & contact-handled & NONACIDIC WASTE SOLID & $\begin{array}{l}\text { Various wastewater streams from } \\
\text { line are processed through an eva } \\
\text { waste stream is the effluent from! }\end{array}$ \\
\hline 8 & ID-SMC-1 $49 A$ & contact-handled & SPENT GM 141 SAPC SOLVENT & $\begin{array}{l}\text { A nonhalogenated organic liquid } \\
\text { point of } 141^{\circ} \mathrm{F} \text {. This waste strean } \\
\text { with waste stream ID-SMC-149B } \\
\text { waste stream. }\end{array}$ \\
\hline 9 & ID-WIN-130-1617 & contact-handled & $\begin{array}{l}\text { MERCURY CONTAM. SOLIDS } \\
\text { SHIELDED W/LEAD }\end{array}$ & $\begin{array}{l}\text { Mercury contaminated blotting pa } \\
\text { massiin wipes. plastic bags, vacu } \\
\text { hose, and floor sweepings. Smal } \\
\text { free mercury. Waste generated b } \\
\text { in G-Cell. }\end{array}$ \\
\hline 10 & ID-WIN-131-MWF & contaci.handled & $\begin{array}{l}\text { MERCURY CONTAMINATED } \\
\text { SOLIDS }\end{array}$ & $\begin{array}{l}\text { Paper, rags, absorbent materials, } \\
\text { contaminated with mercury. Incl } \\
\text { clothing a:d contaminated equipm }\end{array}$ \\
\hline 11 & ID-EGO-166-MWF & contact-handled & WERF HEPA FILTERS AND LEAD & $\begin{array}{l}\text { HEPA filters used to control emis } \\
\text { incinerator and lead shot inside st }\end{array}$ \\
\hline 12 & ID-EGG-128 & unknown & $\begin{array}{l}\text { LABORATORY EQUIPMENT AND } \\
\text { DEBRIS }\end{array}$ & $\begin{array}{l}\text { Sludge samples from the TRA W: } \\
\text { and laboratory equipmenVdehris. } \\
\text { ranges in consistency from liquid } \\
\text { The laboratory equipment and del } \\
\text { contaminated glass. rubber, plasti } \\
\text { products. }\end{array}$ \\
\hline \multicolumn{5}{|c|}{22} \\
\hline
\end{tabular}




\begin{tabular}{|c|c|c|c|}
\hline & $\begin{array}{c}\text { Annual } \\
\text { Volume }\end{array}$ & EPA Codes & $\begin{array}{l}\text { Potential Treatment Strategies } \\
(f b=\text { followed by },<=\text { if necessary })\end{array}$ \\
\hline $\begin{array}{l}\text { s into a central } \\
\text { ssed through a }\end{array}$ & $8.00 \mathrm{~m}^{3}$ & $\begin{array}{l}\text { D008 Lead } \\
\text { D010 Selenium } \\
\text { DC35 Methyl Ethyl Ketone } \\
\text { F001 (Unknown Solvent) } \\
\text { F001 (Unknown Solvent) } \\
\text { F003 (Unknown Solvent) }\end{array}$ & $\begin{array}{l}\text { Waste is treated by the generator, no offsite treatment } \\
\text { required. The residue from drum evaporator is addressed } \\
\text { by waste stream ID ID-SMC-136, NONACIDIC WASTE } \\
\text { SOLID. }\end{array}$ \\
\hline $\begin{array}{l}\text { from the TRA } \\
\text { ning arsenic, } \\
y, \text { silver. }\end{array}$ & $6.0 \mathrm{~m}^{3}$ & $\begin{array}{l}\text { D004 Arsenic } \\
\text { D006 Cadmium } \\
\text { D007 Chromium } \\
\text { D008 Lead } \\
\text { D009 Low mercury }<260 \mathrm{mg} / \mathrm{Kg} \\
\text { D011 Silver }\end{array}$ & $\begin{array}{l}\text { - } \quad \text { Pretreatment }>\text { to destroy cyanices, sulfides, and to } \\
\text { convert arsenic to calcium arsenate } f b \text { vitrification } \\
\text { (TT11000) } f b \text { off-gas treatment (TT23000) } f b \text { stabilization } \\
\text { (TT12000) of the off-gas system sludges. }\end{array}$ \\
\hline $\begin{array}{l}\text { production } \\
\text { orator. This } \\
\text { he evaporator. }\end{array}$ & $4.00 \mathrm{~m}^{3}$ & $\begin{array}{l}\text { D008 Lead } \\
\text { D010 Selenium }\end{array}$ & - Stabilization (TT12000). \\
\hline $\begin{array}{l}\text { ith a flash } \\
\text { is consolidated } \\
\text { hio a singie }\end{array}$ & $2.00 \mathrm{~m}^{3}$ & $\begin{array}{l}\text { D006 Cadmium } \\
\text { D007 Chromium } \\
\text { D008 Lead }\end{array}$ & $\begin{array}{l}\text { Incineration (TT9000) } f b \text { off-gas trealment }(T r 23000) f b \\
\text { stabilization (TT12000) of the ash and off-gas system } \\
\text { residues. } \\
\text { - Same as first option, but the incinerator ash and off-gas } \\
\text { system residues may require a chromium reduction } \\
\text { (TT16700) step to meet TCLP requirements. }\end{array}$ \\
\hline $\begin{array}{l}\text { er, clothing, } \\
\text { m parts, air } \\
\text { container of } \\
\text { mercury spill }\end{array}$ & $1.83 \mathrm{~m}^{3}$ & $\begin{array}{l}\text { D009 High-Mercury > }>=260 \\
\mathrm{mg} / \mathrm{Kg}\end{array}$ & $\begin{array}{l}\text { Amalgamation (TT12300) of free mercury with zinc, and } \\
\text { incineration (TT9000) of contaminated debris } f b \\
\text { stabilization (TT12000) of ash and off-gas system } \\
\text { (TT23000) residues. }\end{array}$ \\
\hline $\begin{array}{l}\text { nd metal } \\
\text { des protective } \\
\text { nt. }\end{array}$ & $1.40 \mathrm{~m}^{3}$ & $\begin{array}{l}\text { D009 High-Mercury }>=260 \\
\mathrm{mg} / \mathrm{kg}\end{array}$ & $\begin{array}{l}\text { Incineration (TT9000) } f b \text { stabilization (Tr12000) of ash, } \\
\text { non-incinerables and off-gas system (TT23000) residues. }\end{array}$ \\
\hline $\begin{array}{l}\text { ions of WERF } \\
\text { el containers. }\end{array}$ & $0.90 \mathrm{~m}^{3}$ & $\begin{array}{l}\text { D006 Cadmium } \\
\text { D008 Radioactive lead solids }\end{array}$ & $\begin{array}{l}\text { - Separate lead waste and process with ID-EGG-143-MWF } \\
\text { and ID-WTN-143 waste sireams. Process HEPA filters } \\
\text { by sizing (TT14000) } f b \text { incineration (TT9000) } f b \\
\text { stabilization (TT12000) of the ash. non-incinerables, and } \\
\text { off-gas system (TT23000) residues. }\end{array}$ \\
\hline $\begin{array}{l}\text { Waste Pond } \\
\text { The sludge } \\
\text { moist solid. } \\
\text { is consists of } \\
\text { and paper }\end{array}$ & $0.42 \mathrm{~m}^{3}$ & $\begin{array}{l}\text { D004 Arsenic } \\
\text { D005 Barium } \\
\text { D006 Cadmium } \\
\text { D007 Chromium } \\
\text { D008 Lead } \\
\text { D009 Low-Mercury }<260 \mathrm{mg} / \mathrm{Kg} \\
\text { D011 Silver }\end{array}$ & $\begin{array}{l}\text { - < Pretreatmeni }>\text { to convert arsenic to calcium arsenate } \\
f b \text { vitrification (TT11000) } f b \text { off-gas treatment (TI2300) } \\
f b \text { stabilization (TT12000) of the off-gas system sludges. }\end{array}$ \\
\hline
\end{tabular}


Table 3. (continued).

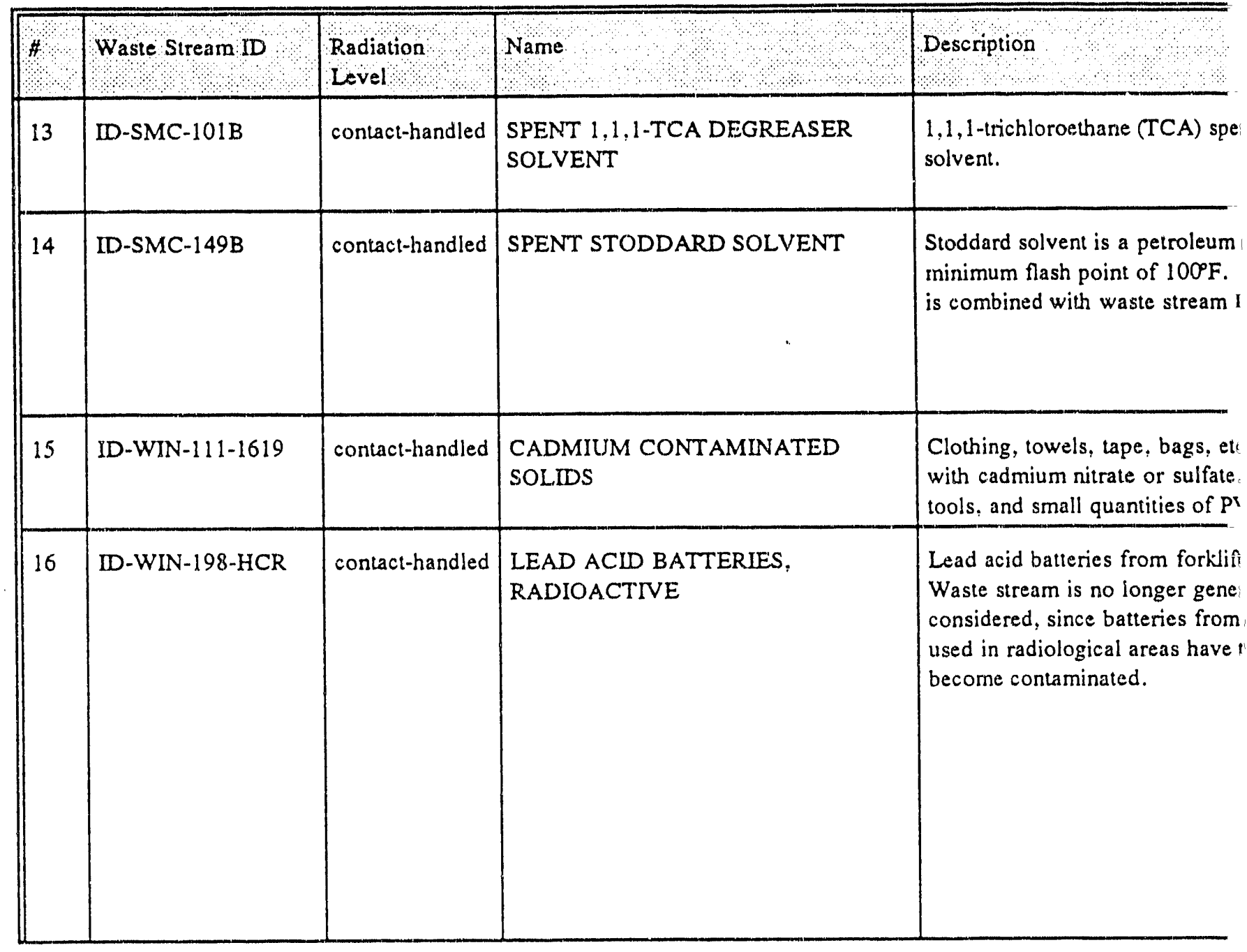




\begin{tabular}{|c|c|c|c|}
\hline & Annual & EPA Codes & $\begin{array}{l}\text { Potential Treatment strategies } \\
(f b=\text { followed by, }<>=\text { if necessary })\end{array}$ \\
\hline it degreaser & $0.40 \mathrm{~m}^{3}$ & $\begin{array}{l}\text { F001 } 1,1,1-\text { Trichloroethane - }> \\
\text { spent halogenated solvent } \\
\text { used in degreasing }\end{array}$ & $\begin{array}{l}\text { - Incineration (TT9000) } f b \text { off-gas treatment (TT23000) } f b \\
\text { stabilization (TT12000) of the ash and off-gas system } \\
\text { residues. }\end{array}$ \\
\hline $\begin{array}{l}\text { iistillate with a } \\
\text { Ihis waste stream } \\
\text { J-SMC-149A. }\end{array}$ & $0.40 \mathrm{~m}^{3}$ & $\begin{array}{l}\text { D001 Ignitable TOC }>10 \% \\
\text { D006 Cadmium } \\
\text { D007 Chromium } \\
\text { D008 Lead }\end{array}$ & $\begin{array}{l}\text { Incineration (TT9000) fb off-gas treatment (TT23000) } f b \\
\text { stabilization (TT12000) of the ash and off-gas system } \\
\text { residues. } \\
\text { Same as first option, but the incinerator ash and off-gas } \\
\text { system residues may require a chromium reduction } \\
\text { (TT16700) step to meet TCLP requirements. }\end{array}$ \\
\hline $\begin{array}{l}\text { contaminated } \\
\text { Some small } \\
\text { C. }\end{array}$ & $0.34 \mathrm{~m}^{3}$ & D006 Cadmium & $\begin{array}{l}\text { - Incineration (TT9000) } f b \text { off-gas treatment (TT23000) } f b \\
\text { stabilization (TT12000) of the ash and off-gas system } \\
\text { residues. }\end{array}$ \\
\hline $\begin{array}{l}\text { equipment. } \\
\text { ited, but } \\
\text { other equipment } \\
\text { te potential to }\end{array}$ & $0.33 \mathrm{~m}^{3}$ & D008 Lead-acid batteries & $\begin{array}{l}\text { Separate batteries into lead, plastic, and liquid waste } \\
\text { streams. Precipitation of metals from liquid (TT6200) } f b \\
\text { filtration (TT1000) of precipitate, recycle the lead using } \\
\text { high-temperature metals recovery (TT15000), and } \\
\text { incinerate (TT9000) the plastic cases. Stabilize } \\
\text { (TT12000) the off-gas system (TT23000) residues, ash, } \\
\text { and precipitated sludges. } \\
\text { Decontamination (TT200) of battery case for reuse } f b \\
\text { stabilization of process sludges. } \\
\text { Drain liquid from the batteries. Macroencapsulate } \\
\text { (TT12900) batteries. Precipitation of metals from liquid } \\
\text { (TT6200) fb filtration (TT1000) fh stabilization } \\
\text { (TT12000) of the solids. }\end{array}$ \\
\hline
\end{tabular}


Table 3. (continued).

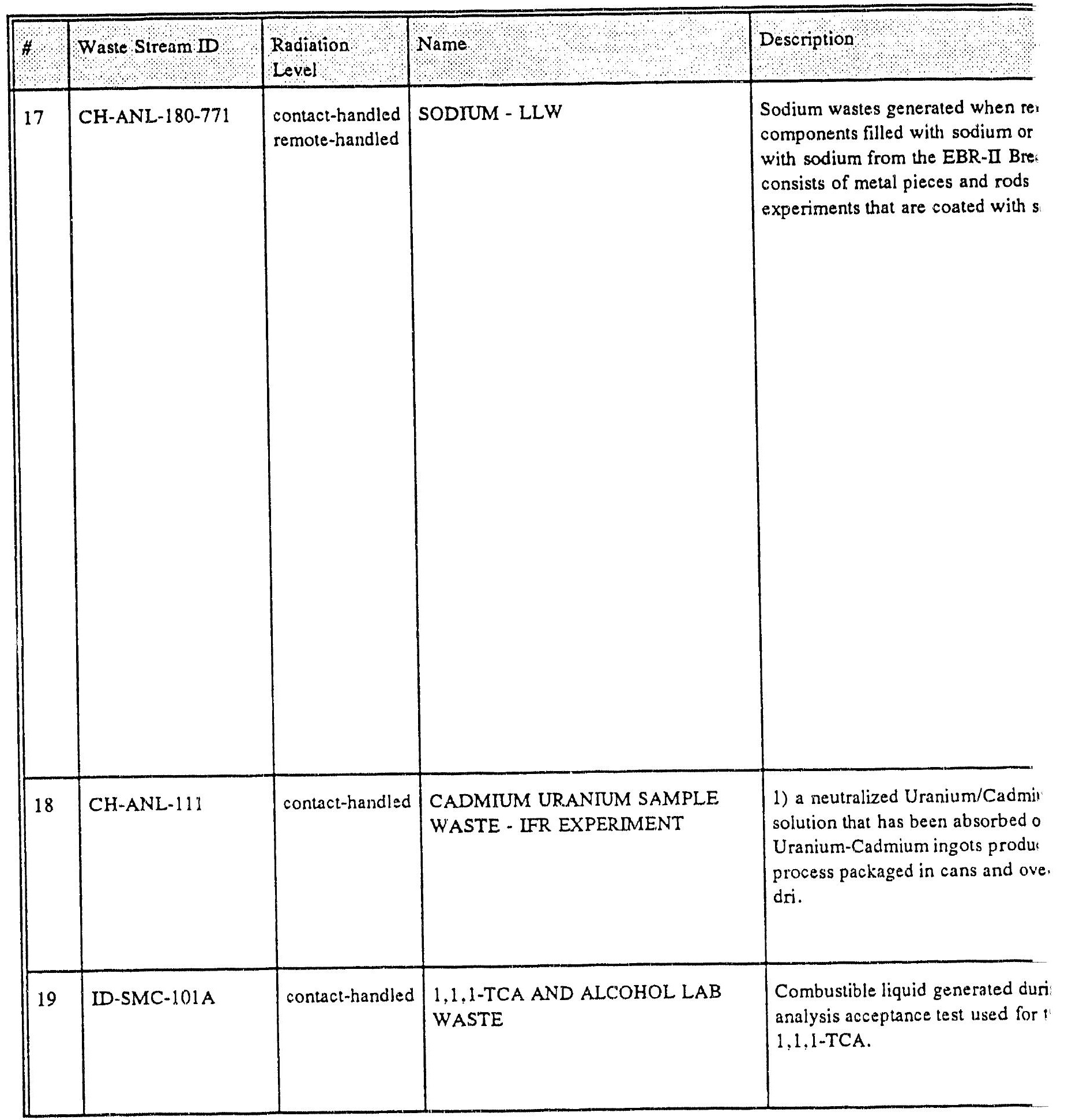




\begin{tabular}{|c|c|c|c|}
\hline & Annual & EPA Codes & $\begin{array}{l}\text { Potential Treatment strategies } \\
(f b=\text { followed by, }<>=\text { if necessary })\end{array}$ \\
\hline $\begin{array}{l}\text { hoving } \\
\text { ontaminated } \\
\text { der Reactor. It } \\
\text { fom reactor } \\
\text { dium metal. }\end{array}$ & $0.23 \mathrm{~m}^{3}$ & $\begin{array}{l}\text { D001 Ignitible Reactive } \\
\text { D003 Reactive Water Reactive }\end{array}$ & $\begin{array}{l}\text { Shredding (TT14500) or cryofracture (TT14600) } f b \\
\text { controlled water reaction* (TT16900) } f b \text { solid liquid } \\
\text { separation (TT6400) with the liquids being neutralized } \\
\text { (TT16600) } f b<\text { evaporation (TT4000) }>f b \text { stabilization } \\
\text { (TT12000), and the solids being < volume reduced } \\
\text { (TT8000) }>f b \text { stabilization (TT12000). } \\
\text { Shredding (TT14500) or cryofracture (TT14600) } f b \\
\text { controlled water reaction* (TT16900) } f b \text { solid liquid } \\
\text { separation (TT6400) with the liquids being calcined } \\
\text { (TT10100) } f b \text { stabilization (TT12000), and the solids } \\
\text { being < volume reduced (TT8000) }>f b \text { stabilization } \\
\text { (TT12000). } \\
\text { Shredding (TT14500) or cryofracture (TT14600) } f b \\
\text { chemical oxidation* (TT16700) with alcohol } f b \text { solid } \\
\text { liquid separation (TT6400) with the solution being } \\
\text { incinerated (TT9000) } f b \text { stabilization (TT12000) of ash } \\
\text { and off-gas system (TT23000) residues, and the solids } \\
\text { being < volume reduced (TT8000) }>f b \text { stabilization } \\
\text { (TT1200) } \\
\text { Shredding (TT14500) or cryofracture (TT14600) } f b \\
\text { chenical oxidation* (TT16700) with alcohol } f b \text { solid } \\
\text { liquid separation (TT6400) with the solution being } \\
\text { neutralized (TT16600) } f b \text { distillation (TT6550),fb } \\
\text { stabilization (IT12000), and the solids being < volume } \\
\text { reduced (TT8000) }>f b \text { stabilization (TT12000) } \\
\text { * Note: the off-gas from these processes will be purged to an } \\
\text { incinerator }\end{array}$ \\
\hline $\begin{array}{l}\text { alloy in acid } \\
\text { oil dri, and } 2 \text { ) } \\
\text { d by the } \\
\text { packed in oil }\end{array}$ & $0.21 \mathrm{~m}^{3}$ & D006 Cadmium & $\begin{array}{l}\text { Manual segregation of the waste into U-Cd ingots and } \\
\text { contaminated oil dri } f b \text { macroencapsulation (TT12900) of } \\
\text { the ingots and stabilization (TT12000) of the oil-dri. } \\
\text { Manual segregation of the waste into U-Cd ingots and } \\
\text { contaminated oil dri } f b \text { metals recovery (TT15000) of the } \\
\text { ingots and stabilization (TT12000) of the oil-dri. }\end{array}$ \\
\hline e testing of & $0.20 \mathrm{~m}^{3}$ & $\begin{array}{c}\text { F001 } 1,1,1 \text {-Trichloroethane - > } \\
\text { spent halogenated solvent } \\
\text { used in degreasing }\end{array}$ & $\begin{array}{l}\text { - Incineration (TT9000) } f b \text { off-gas treatment (TT23000) } f b \\
\text { stabilization (TT12000) of the ash and off-gas system } \\
\text { residues. }\end{array}$ \\
\hline
\end{tabular}


Table 3. (continued).

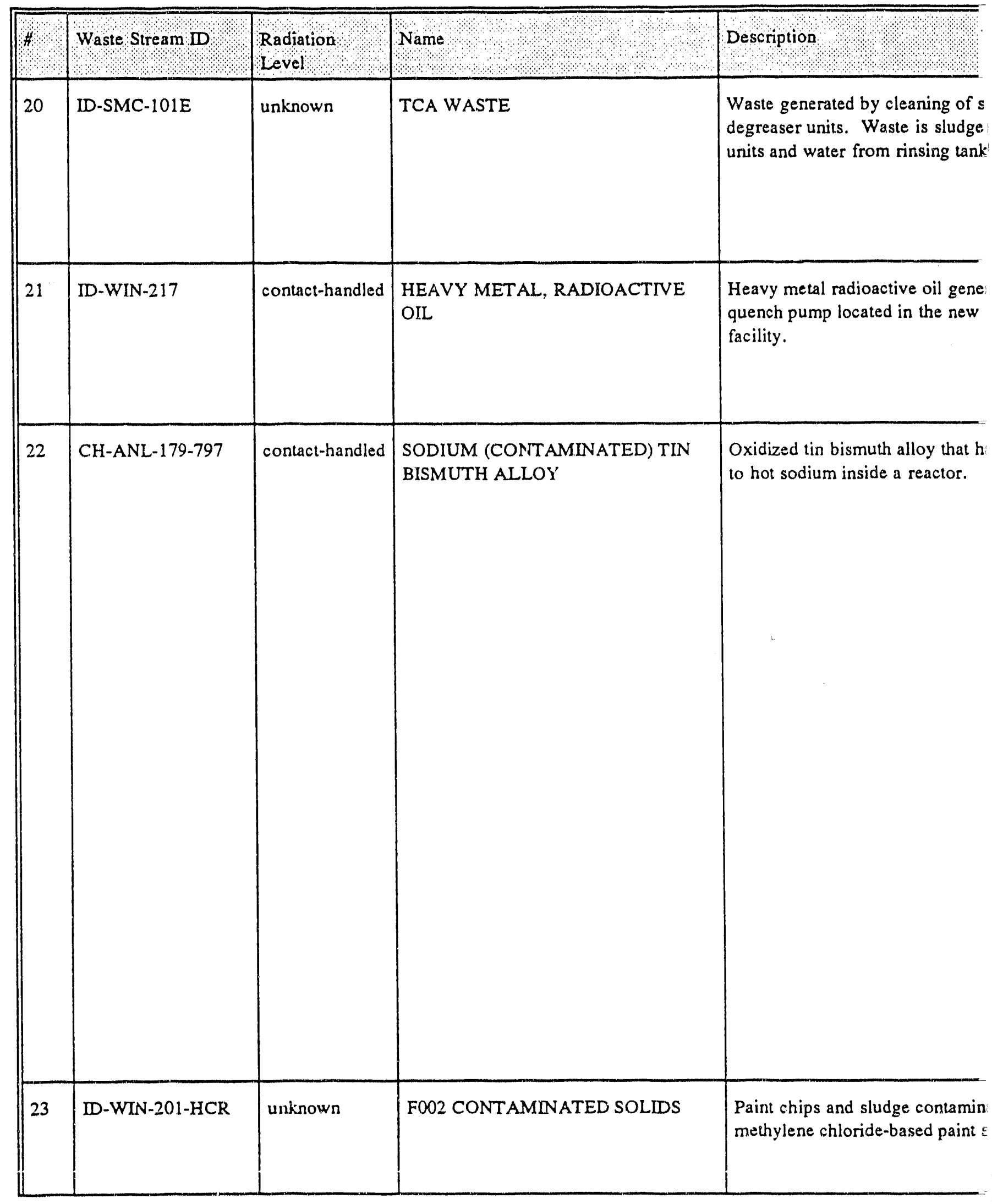




\begin{tabular}{|c|c|c|c|}
\hline & Annual & EPA Codes & Potential Treatment strategies \\
\hline $\begin{array}{l}\text { lvent based } \\
\text { from bottom of }\end{array}$ & $0.20 \mathrm{~m}^{3}$ & $\begin{array}{c}\text { F001 } \\
\text { 1,1,1-Trichloroethane }-> \\
\text { spent halogenated solvent } \\
\text { used in degreasing }\end{array}$ & $\begin{array}{l}\text { - Steam Stripping (TT67000) } f b \text { phase separation of the } \\
\text { condensate(TT6000) and release of the treated effluent per } \\
\text { NPDES permit } f b \text { Incineration (TT9000) of the organics } \\
f b \text { off-gas treatment (TT23000) } f b \text { stabilization (TT12000) } \\
\text { of the ash and off-gas system residues. }\end{array}$ \\
\hline $\begin{array}{l}\text { ated from a } \\
\text { vaste calcining }\end{array}$ & $0.20 \mathrm{~m}^{3}$ & $\begin{array}{l}\text { D007 Chromium } \\
\text { D008 Lead }\end{array}$ & $\begin{array}{l}\text { - Incineration (TT9000) } f b \text { off-gas treatment (TT23000) } f b \\
\text { stabilization (TT12000) of the ash and oif-gas system } \\
\text { residues. } \\
\text { - Same as first option, but the incinerator ash and off-gas } \\
\text { system residues may require a chromium reduction } \\
\text { (TT16700) step to meet TCLP requirements. }\end{array}$ \\
\hline$s$ been exposed & $0.17 \mathrm{~m}^{3}$ & $\begin{array}{l}\text { D001 Ignitible Reactive } \\
\text { D003 Reactive Water Reactive }\end{array}$ & $\begin{array}{l}\text { Shredding (TT14500) or cryofracture (TT14600) } f b \\
\text { controlled water reaction* (TT16900) } f b \text { solid liquid } \\
\text { separation (TT6400) with the liquids being neutralized } \\
\text { (TT16600) } f b<\text { evaporation (TT4000) }>f b \text { stabilization } \\
\text { (TT12000), and the solids being < volume reduced } \\
\text { (TT800) }>f b \text { stabilization (TT12000). } \\
\text { - Shredding (TT14500) or cryofracture (TT14600) } f b \\
\text { controlled water reaction* (TT16900) } f b \text { solid liquid } \\
\text { separation (TT6400) with the liquids being calcined } \\
\text { (TT10100) } f b \text { stabilization (TT12000), and the solids } \\
\text { being < volume reduced (TT8000) }>f b \text { stabilization } \\
\text { (TT12000). } \\
\text { Shredding (TT14500) or cryofracture (TT14600) } f b \\
\text { chemical oxidation* (TT16700) with alcohol } f b \text { solid } \\
\text { liquid separation (TT6400) with the solution being } \\
\text { incinerated (TT9000) } f b \text { stabilization (TT12000) of ash } \\
\text { and off-gas system (TT23000) residues, and the solids } \\
\text { being < volume reduced (TT8000) }>f b \text { stabilization } \\
\text { (TT12000) } \\
\text { Shredding (TT14500) or cryofracture (TT14600) } f b \\
\text { chemical oxidation* (TT16700) with alcohol } f b \text { solid } \\
\text { liquid separation }(T T 6400 \text { ) with the solution being } \\
\text { neutralized (TT16600) } f b \text { distillation (TT6550) } f b \\
\text { stabilization (TT12000), and the solids being < volume } \\
\text { reduced (TT8000) }>f b \text { stabilization (TT12000) } \\
\text { *Note: the off-gas from these processes will be purged to an } \\
\text { incinerator }\end{array}$ \\
\hline $\begin{array}{l}\text { led with residual } \\
\text { ripper. }\end{array}$ & $.16 \mathrm{~m}^{3}$ & $\begin{array}{l}\text { F002 Methylene Chloride -> } \\
\text { spent halogenated solvents }\end{array}$ & $\begin{array}{l}\text { - Incineration (TT9000) } f b \text { off-gas treatment (TT23000) } f b \\
\text { stabilization (TT12000) of the ash and off-gas system } \\
\text { residues. }\end{array}$ \\
\hline
\end{tabular}


Table 3. (continued).

\begin{tabular}{|l|l|l|l|l}
\hline Waste Stream ID & Radiation & Name & Description \\
\hline 24 & CH-ANL-218-IFR & remote-handled & $\begin{array}{l}\text { ELECTROREFINER STRIPPED } \\
\text { SALT - BA AND CD }\end{array}$ & $\begin{array}{l}\text { Alkali metal chlorinate salt that } \\
\text { stream from the Int-gral Fast R } \\
\text { Facility. }\end{array}$ \\
\hline 25 & CH-ANL-183-765 & contact-handled & PAINTSTRIPPING WASTE & $\begin{array}{l}\text { Waste generated from the occas } \\
\text { paint surfaces that are radioactiv }\end{array}$ \\
\hline ID-WIN-197-HCR & contact-handled & $\begin{array}{l}\text { CHROMIUM AND LEAD } \\
\text { CONTAMINATED SOLIDS }\end{array}$ & $\begin{array}{l}\text { Debris from laboratory operatio } \\
\text { shift lab. It contains no liquids. } \\
\text { debris is a combustion tube furn } \\
\text { Conversations with Leroy Lewi: } \\
\text { catalyst is a solid oxide, maybe } \\
\text { expected that at the temperature } \\
\text { combustion furnace, the materia } \\
\text { sintered and may even have bee }\end{array}$ \\
\hline
\end{tabular}




\begin{tabular}{|c|c|c|c|}
\hline & Annual & EPA Codes & $\begin{array}{l}\text { Potential Treatment Strategies } \\
(A b=\text { followed by, }<>=\text { if necessary })\end{array}$ \\
\hline $\begin{array}{l}\text { s a process waste } \\
\text { actor Fuel Cycle }\end{array}$ & $0.11 \mathrm{~m}^{3}$ & $\begin{array}{l}\text { D005 Barium } \\
\text { D006 Cadmium }\end{array}$ & $\begin{array}{l}\text { - Stabilization (TT12000). Note: The alkali metal salts } \\
\text { may make stabilization with common concrete difficult. }\end{array}$ \\
\hline $\begin{array}{l}\text { onal stripping of } \\
\text { ely contaminated. }\end{array}$ & $0.1 \mathrm{~m}^{3}$ & $\begin{array}{l}\text { F002 Methylene Chloride -> } \\
\text { Spent halogenated solvents } \\
\text { F003 Methanol }->\text { Spent non- } \\
\text { halogenated solvents } \\
\text { D008 Lead } \\
\text { D007 Chromium }\end{array}$ & $\begin{array}{l}\text { Incineration (TT9000) } f b \text { off-gas treatment (TT23000) } f b \\
\text { stabilization (TT12000) of the ash and off-gas system } \\
\text { residues. } \\
\text { - Same as first option, but the incinerator ash and off-gas } \\
\text { system residues may require a chromium reduction } \\
\text { (TT16700) step to meet TCLP requirements. }\end{array}$ \\
\hline $\begin{array}{l}\text { s in CPP- } 627 \\
\text { Part of the } \\
\text { pe catalyst. } \\
\text { indicated that the } \\
\text { lumina. It is } \\
\text { in the } \\
\text { has been } \\
\text { vitrified. }\end{array}$ & $.08 \mathrm{~m}^{3}$ & $\begin{array}{l}\text { D007 Chromium } \\
\text { D008 Lead }\end{array}$ & $\begin{array}{l}\text { Physical separation of the combustion tubes from the } \\
\text { rags, paper and plastic } f b \text { incineration (TT9000) of the } \\
\text { rag, paper, and plastic } f b \text { off-gas treatment (TT23000) } f b \\
\text { stabilization (TT12000) of the ash and off-gas system } \\
\text { residues. The combustion tubes will be sent directly to } \\
\text { stabilization (TT12000). }\end{array}$ \\
\hline
\end{tabular}


Table 3. (continued).

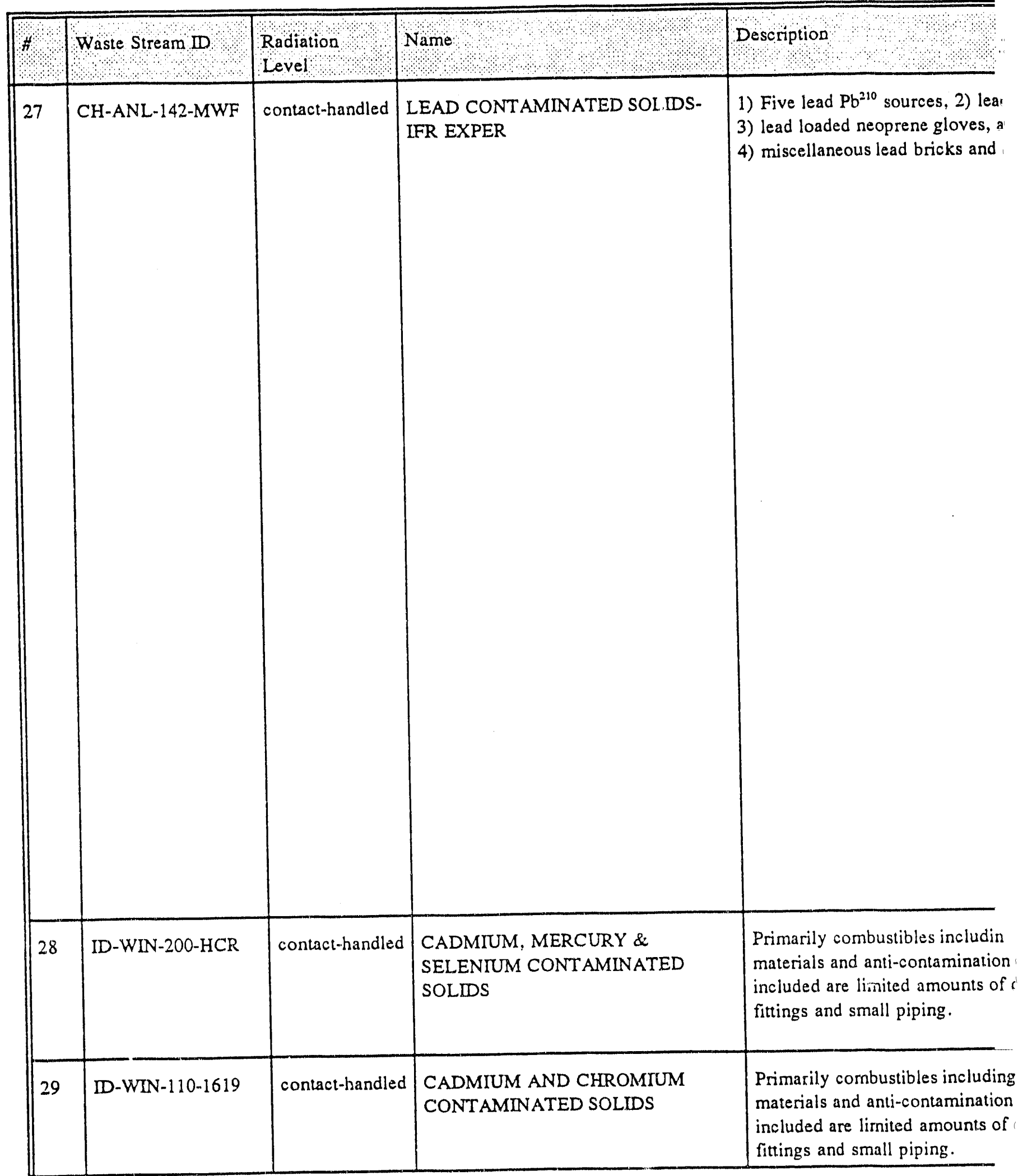




\begin{tabular}{|c|c|c|c|c|}
\hline ४ै। & Anrubal & \multicolumn{2}{|c|}{ EPACodes } & $\begin{array}{l}\text { Potential Treatment strategies } \\
(f b=\text { followed by }<>=\text { if necessary) }\end{array}$ \\
\hline $\begin{array}{l}\text { forklift battery, } \\
\text { id } \\
\text { imings. }\end{array}$ & $0.0716 \mathrm{~m}^{3}$ & \multicolumn{2}{|c|}{ D008 Radioactive lead solids } & $\begin{array}{l}\text { Wastes } 1,2,3 \text {, and } 4 \text { : } \\
\text { - volume reduction > (TT8000) of the lead wastes } f b \\
\text { macroencapsulation (TT12900). } \\
\text { Wastes } 3 \text { and } 4 \text { : } \\
\text { - Separate non-lead scrap metal for volume reduction } \\
\text { (TT800), refine the lead using high-temperature metals } \\
\text { recovery (TT15000) } f b \text { off-gas treatment (TT23000) and } \\
\text { stabilization (TT12000) of slag and off-gas system } \\
\text { residues. } \\
\text { Waste } 2 \text { : } \\
\text { - Separate batteries into lead, plastic, and liquid waste } \\
\text { streams. Precipitation (TT6200) } f b \text { filtration (TT100) of } \\
\text { metals from liquid, recycle the lead using high- } \\
\text { temperature metals recovery (TT15000), and incinerate } \\
\text { (TT9000) the plastic cases. Stabilize (TT12000) the off- } \\
\text { gas system (TT23000) residues, ash, and precipitated } \\
\text { sludges. } \\
\text { Decontamination (TT200) of battery case for reuse } f b \\
\text { stabilization of process sludges, etc. } \\
\text { Drain liquid from the batteries. Macroencapsulate } \\
\text { (TT12900) batteries. Precipitation (TT6200) fb filtration } \\
\text { (TT1000) of metals from liquid } f b \text { stabilization (TT12000) } \\
\text { of the solids. } \\
\text { Waste } 3: \\
\text { Separate scrap lead pieces from other waste and send to } \\
\text { lead treatment (one of the } 3 \text { options above). < size }> \\
\text { (TT14000) the remaining waste for incineration (TT } 9000 \text { ) } \\
f b \text { stabilization (TT12000) of the ash and off-gas system } \\
\text { residues. } \\
\text { Waste } 4: \\
\text { Decontamination (TT2000) of the lead for reuse by } \\
\text { removal of the outer contaminated layer } f b \text { stabilization } \\
\text { (TT12000) of the resulting residues. }\end{array}$ \\
\hline $\begin{array}{l}\text { absorbent } \\
\text { rear. Also } \\
\text { iscarded tubing, }\end{array}$ & $0.06 \mathrm{~m}^{3}$ & $\begin{array}{l}\text { D0n6 } \\
\text { Du09 } \\
\text { D010 }\end{array}$ & $\begin{array}{l}\text { Cadmium } \\
\text { Low-Mercury }<260 \\
\mathrm{Mg} / \mathrm{Kg} \\
\text { Selenium }\end{array}$ & $\begin{array}{l}\text { - Incineration (TT9000) } f b \text { stabilization } \\
\text { (TT12000)/Vitrification (TT11000) of ash and off-gas } \\
\text { system (TT23000) residues. }\end{array}$ \\
\hline $\begin{array}{l}\text { absorbent } \\
\text { ?ear. Also } \\
\text { iscarded tubing, }\end{array}$ & $0.04 \mathrm{~m}^{3}$ & $\begin{array}{l}\text { D006 } \\
\text { D007 }\end{array}$ & $\begin{array}{l}\text { Cadmium } \\
\text { Chromium }\end{array}$ & $\begin{array}{l}\text { - Incineration (TT9000) } f b \text { stabilization (TT12000) of ash } \\
\text { and off-gas system (TT23000) residues. }\end{array}$ \\
\hline
\end{tabular}


Table 3. (continued).

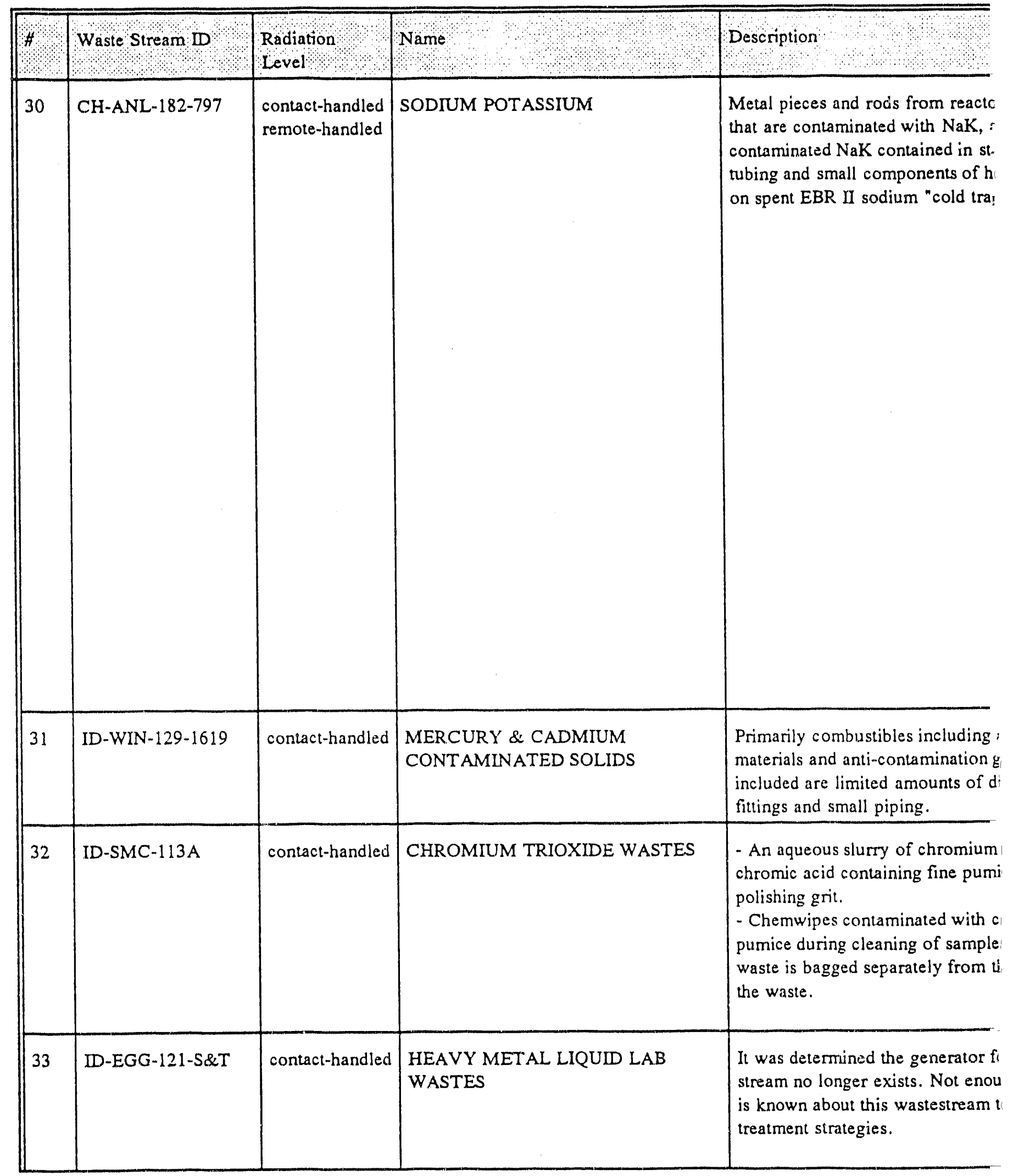




\begin{tabular}{|c|c|c|c|}
\hline & $\begin{array}{l}\text { Annual } \\
\text { Volume }\end{array}$ & EPA Codes & $\begin{array}{l}\text { Potential Trealment strategies } \\
(f b=\text { followed by, }<>=\text { if necessary })\end{array}$ \\
\hline $\begin{array}{l}\text { experiments } \\
\text { hd } \\
\text { injess steel } \\
\text { at exchangers } \\
\text { s". }\end{array}$ & $0.0400 \mathrm{~m}^{3}$ & $\begin{array}{l}\text { D001 Ignitible Reactive } \\
\text { D003 Reactive Water Reactive }\end{array}$ & 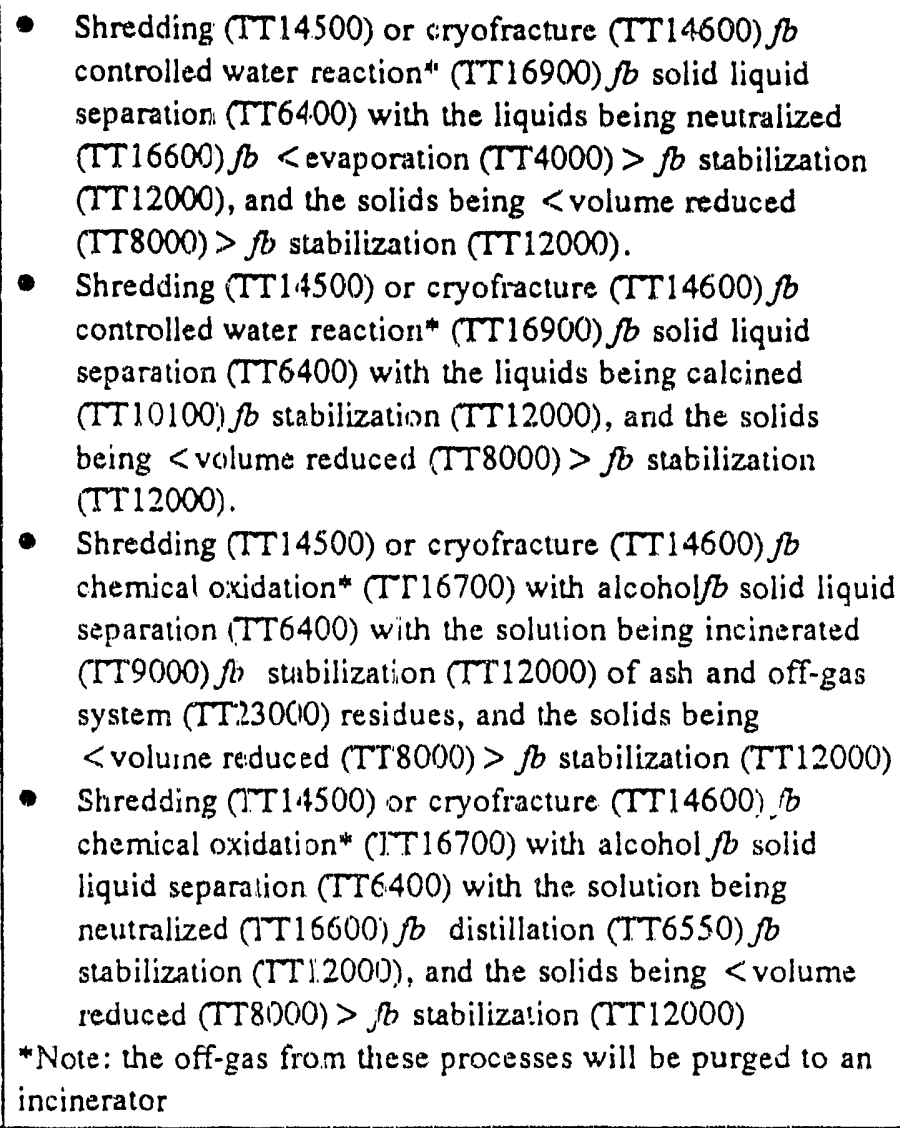 \\
\hline $\begin{array}{l}\text { bsorbent } \\
\text { ear. Aiso } \\
\text { scarded tubing. }\end{array}$ & $0.0270 \mathrm{~m}^{3}$ & $\begin{array}{ll}\text { D006 } & \text { Cadmium } \\
\text { D009 } & \text { High-Mercury }>=260 \\
& \mathrm{mg} / \mathrm{Kg}\end{array}$ & $\begin{array}{l}\text { Incineration (Tr9000) } f b \text { off-gas treatment }(T T 23000) f b \\
\text { stabilization (TT120(0)) of the ash and off-gas system } \\
\text { residues. }\end{array}$ \\
\hline $\begin{array}{l}\text { rioxide, i.e., } \\
\text { promium that is a } \\
\text { The paper } \\
\text { e liquid part of }\end{array}$ & $0.02 \mathrm{~m}^{3}$ & Chromium & $\begin{array}{l}\text { Incineration (TTSOC0) of combustible solids } f b \text { off-gas } \\
\text { treatment (TT23000) } f b \text { chromium reduction (TT16700) } \\
\text { of the incinerator ash and off-gas system residues } f b \\
\text { stabilization (TT12(100). The slurry will need chromium } \\
\text { reduction (TT167(1)) } f b \text { stabilization (TT12000). }\end{array}$ \\
\hline $\begin{array}{l}\text { this waste } \\
\text { propose }\end{array}$ & N/A & N/A & $N / A$ \\
\hline
\end{tabular}


Table 3. (continued).

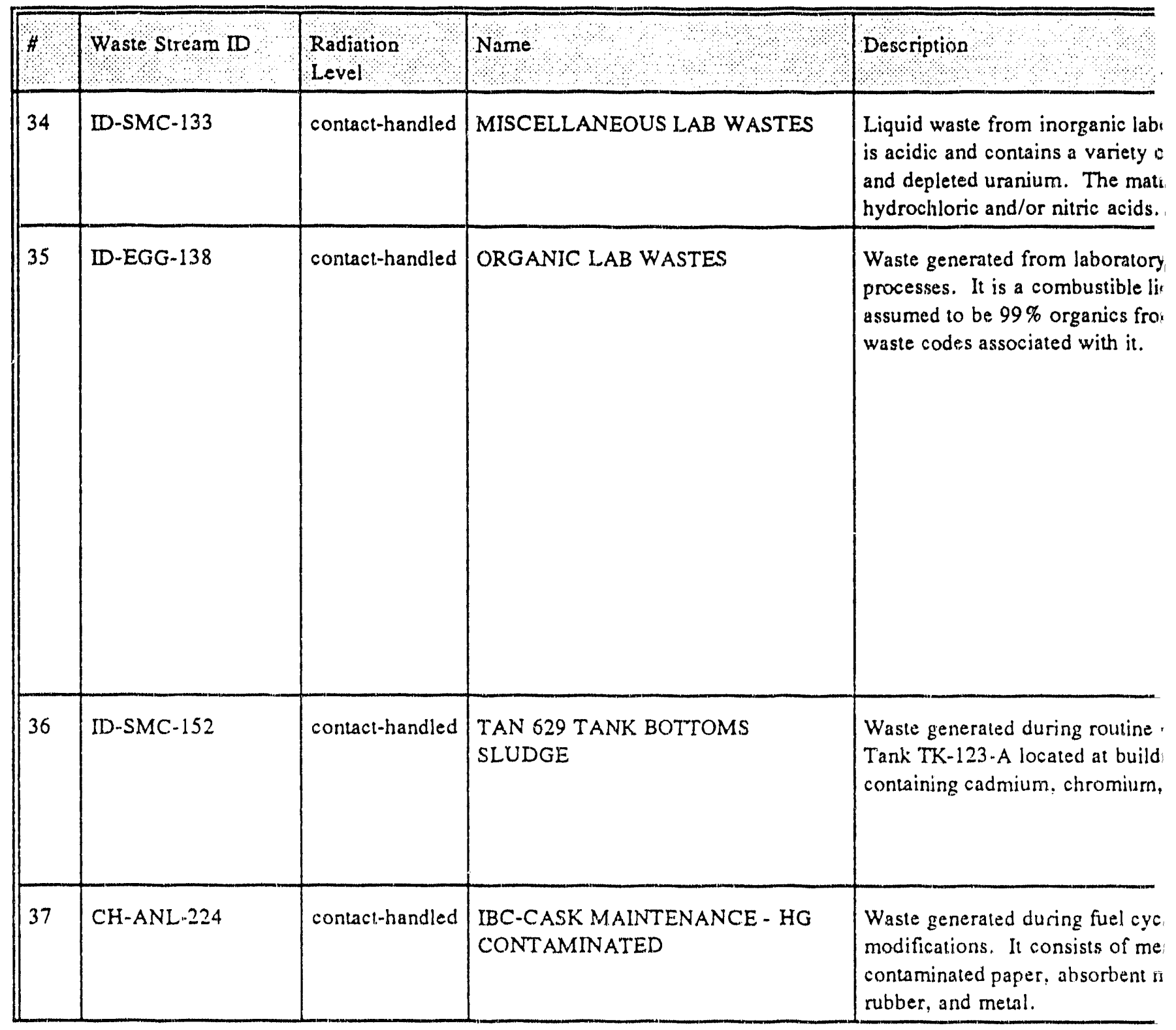




\begin{tabular}{|c|c|c|c|}
\hline & Annual & EPA Codes & $\begin{array}{l}\text { Potential Treatment Strategies } \\
(A B=\text { followed by, }<>=\text { if necessary })\end{array}$ \\
\hline $\begin{array}{l}\text { ratory R\&D. It } \\
\text { heavy metals } \\
x \text { is }\end{array}$ & $0.02 \mathrm{~m}^{3}$ & $\begin{array}{l}\text { D006 Cadmium } \\
\text { D007 Chromium } \\
\text { D008 Lead } \\
\text { D010 Selenium }\end{array}$ & $\begin{array}{l}\text { - Reduction of chromium (TT16700) fb stabilization } \\
\text { (TT12000). }\end{array}$ \\
\hline $\begin{array}{l}\text { analytical } \\
\text { uid and is } \\
h \text { the hazardous }\end{array}$ & $0.02 \mathrm{~m}^{3}$ & 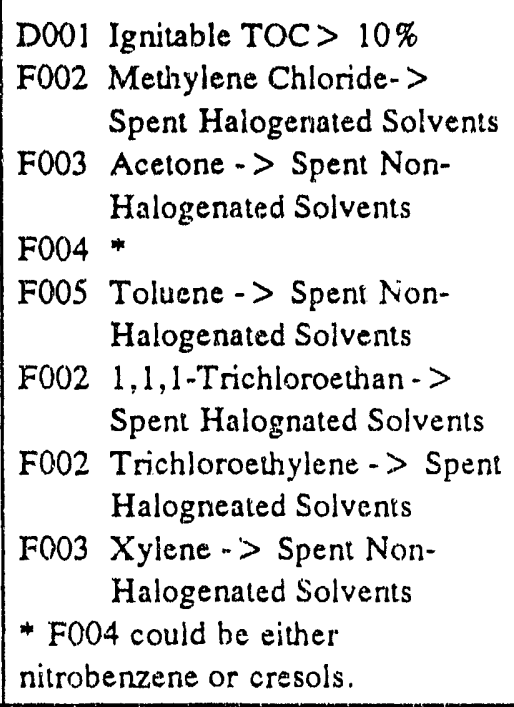 & $\begin{array}{l}\text { - Incineration (TT9000) } f b \text { stabilization (TT12000) of ash } \\
\text { and off-gas system (TT23000) residues. }\end{array}$ \\
\hline $\begin{array}{l}\text { naintenance of } \\
\text { ng TAN } 629 \\
\text { and lead. }\end{array}$ & $0.02 \mathrm{~m}^{3}$ & $\begin{array}{l}\text { D001 Ignitable TOC }>10 \% \\
\text { D006 Cadmium } \\
\text { D007 Chromium } \\
\text { D008 Lead }\end{array}$ & $\begin{array}{l}\text { Incineration (TT9000) } f b \text { off-gas treatment (TT23000) } f b \\
\text { stabilization (TT12000) of the ash and off-gas system } \\
\text { residues. } \\
\text { Same as first option, but the incinerator ash and off-gas } \\
\text { system residues may require a chromium recluction } \\
\text { (TT16700) step to meet TCLP requirements. }\end{array}$ \\
\hline $\begin{array}{l}\text { facility } \\
\text { cury } \\
\text { aterial, plastic, }\end{array}$ & $0.02 \mathrm{~m}^{3}$ & $\begin{array}{l}\text { D009 High-Mercury > }=260 \\
\mathrm{mg} / \mathrm{Kg}\end{array}$ & $\begin{array}{l}\text { - Incineration (TT9000) } f b \text { off-gas treatment }(T T 23000) f b \\
\text { stabilization (TT12000) of the ash and off-gas system } \\
\text { residues. }\end{array}$ \\
\hline
\end{tabular}


Table 3. (continued).

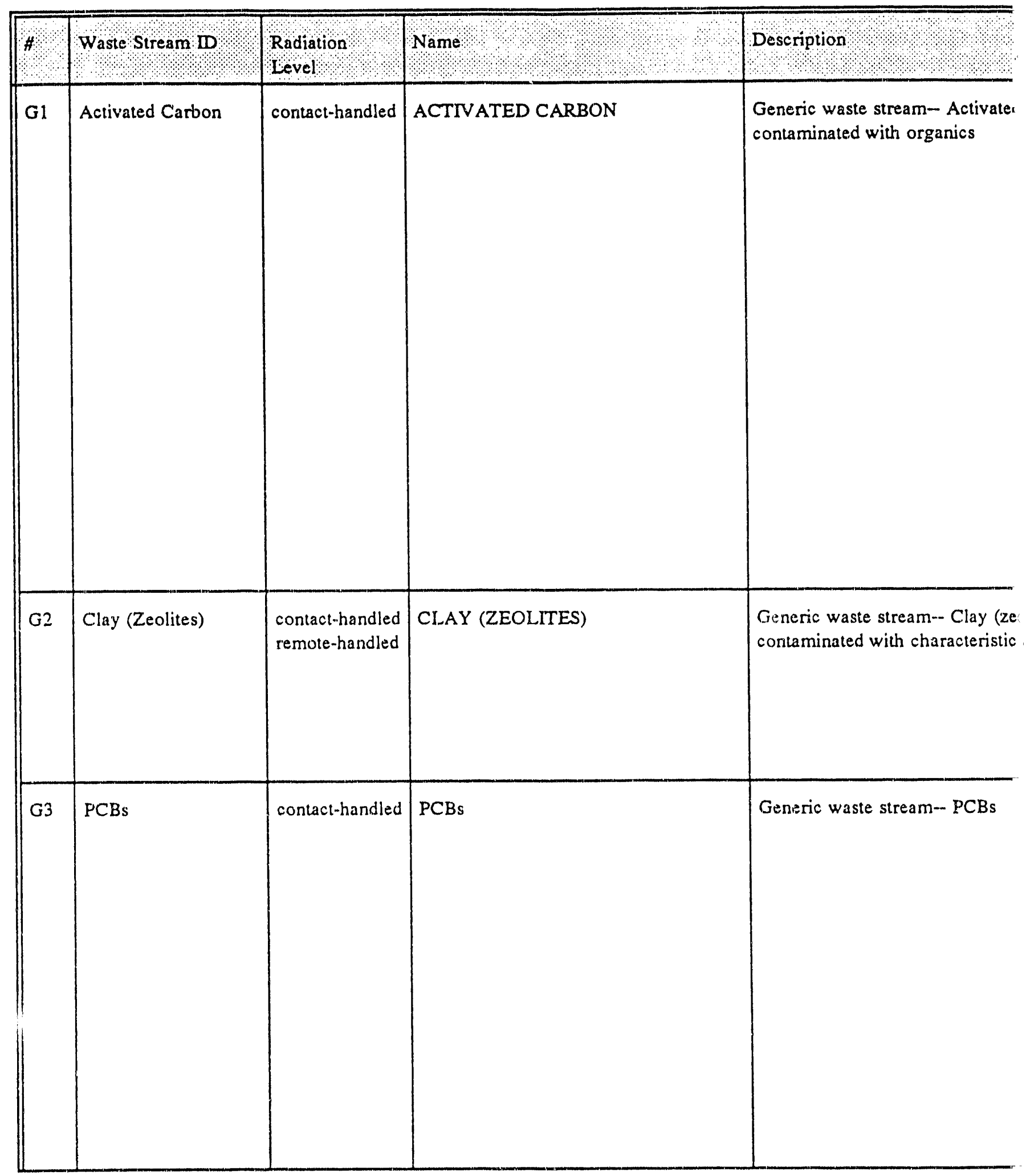




\begin{tabular}{|c|c|c|c|}
\hline & $\begin{array}{c}\text { Annual } \\
\text { Volume }\end{array}$ & EPA Codes & $\begin{array}{l}\text { Potential Treatment Strategies } \\
(f b=\text { followed by },<>=\text { if necessary })\end{array}$ \\
\hline carbon & $1.0 \mathrm{~m}^{3}$ & 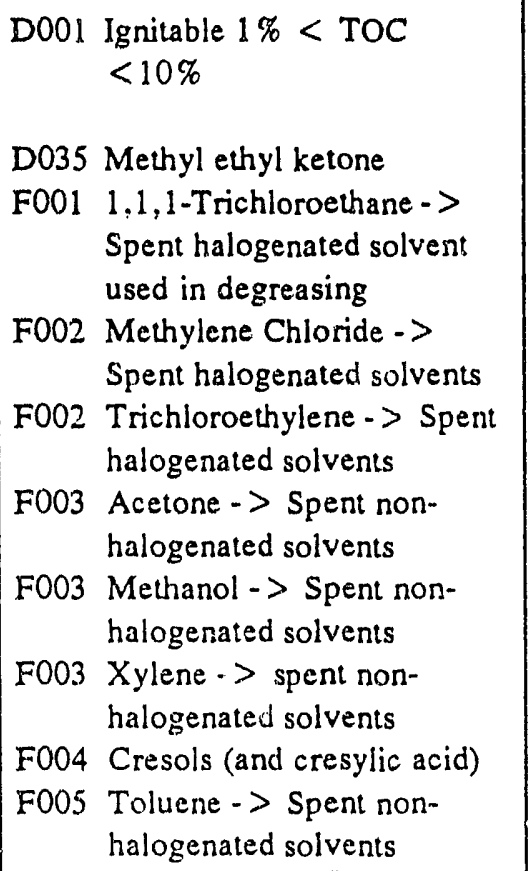 & $\begin{array}{l}\text { - Incineration (TT9000) } f b \text { off-gas ireatment (TT23000) } f b \\
\text { stabilization of incinerator ash and off-gas treatment } \\
\text { solids by solidification (TT12000). }\end{array}$ \\
\hline \multirow[t]{2}{*}{$\begin{array}{l}\text { lites) } \\
\text { netals }\end{array}$} & $0.4 \mathrm{~m}^{3}$ & $\begin{array}{l}\text { D005 Barium } \\
\text { D006 Cadmium } \\
\text { D007 Chromium } \\
\text { D008 Lead } \\
\text { D009 Low-mercury }<260 \mathrm{mg} / \mathrm{kg}^{\prime} \\
\text { D010 Selenium } \\
\text { D011 Silver }\end{array}$ & $\begin{array}{l}\text { - Vitrification (TT9000) } f b \text { off-gas treatment (TT23000) } f b \\
\text { stabilization of off-gas system residues (TT12000) } \\
\text { - Stabilization (TT12000) }\end{array}$ \\
\hline & $0.2 \mathrm{~m}^{3}$ & $n / a$ & 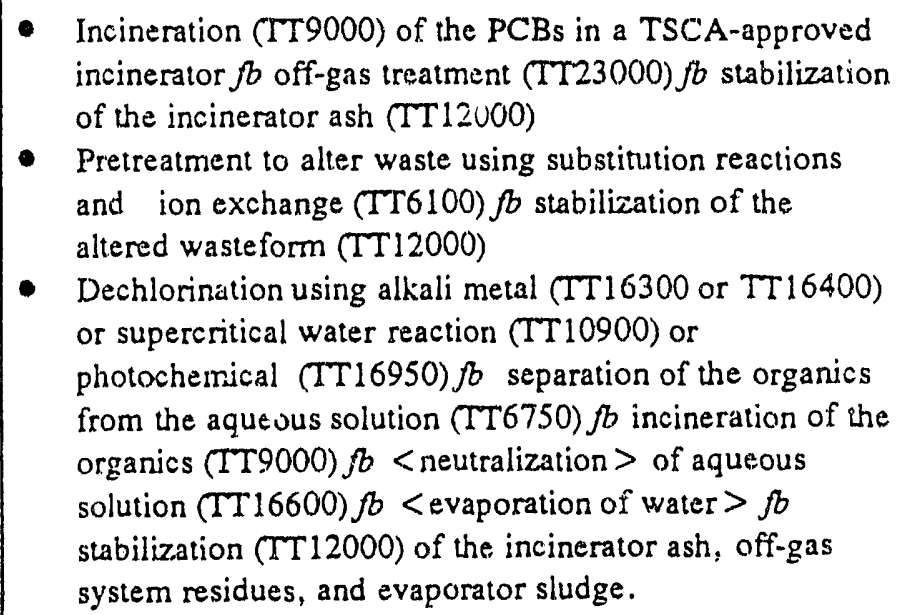 \\
\hline
\end{tabular}


Table 3. (continued).

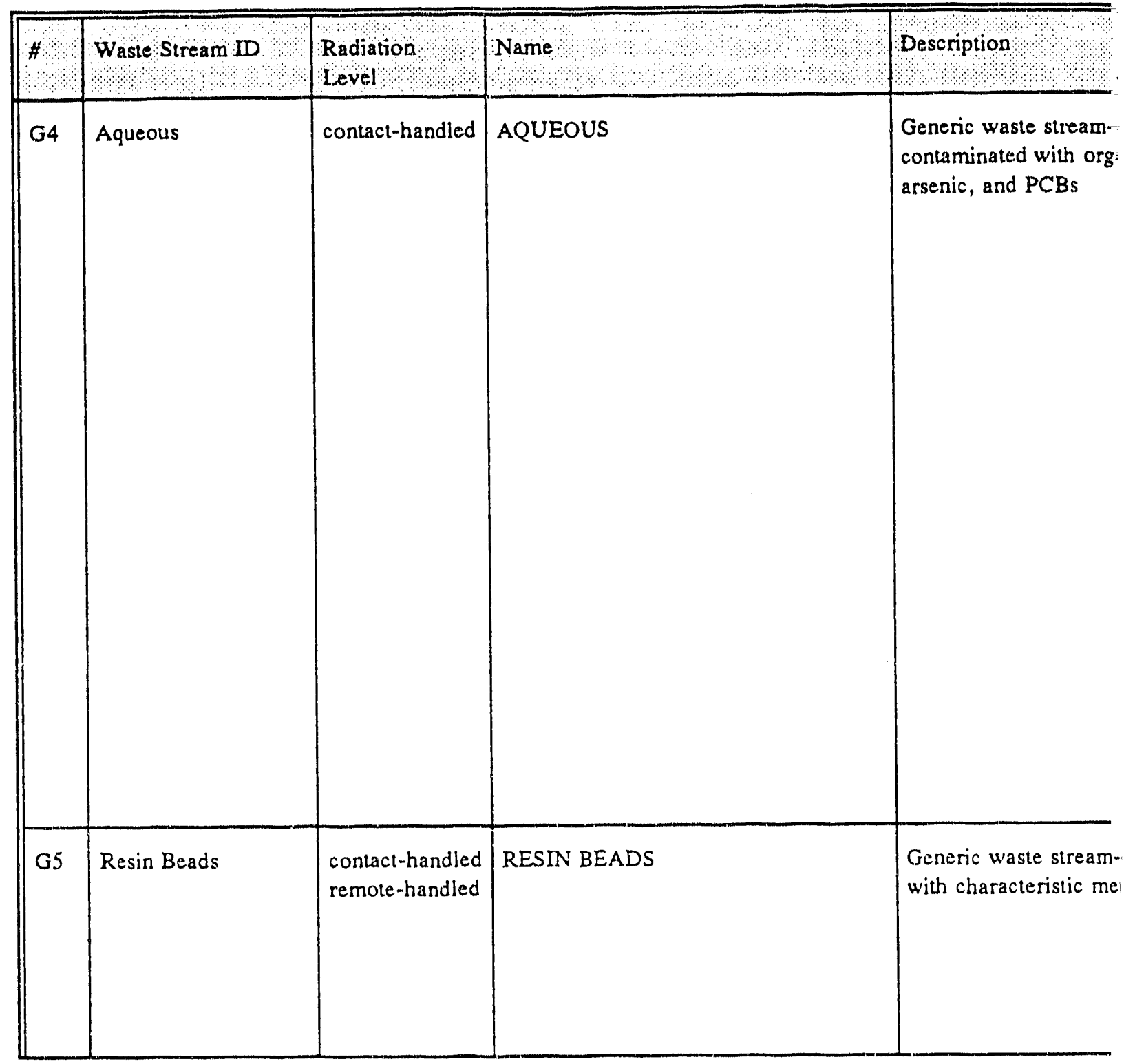




\begin{tabular}{|c|c|c|c|}
\hline 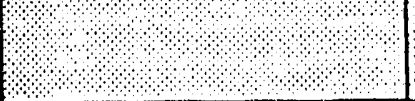 & Annual & EPA Codes & $\begin{array}{l}\text { Potential Treatent Strategies } \\
\text { (fb }=\text { followed by, }<>\text { if necessary) }\end{array}$ \\
\hline $\begin{array}{l}\text { Aqueous solutions } \\
\text { nics, characteristic metals, }\end{array}$ & $10.0 \mathrm{~m}^{3}$ & 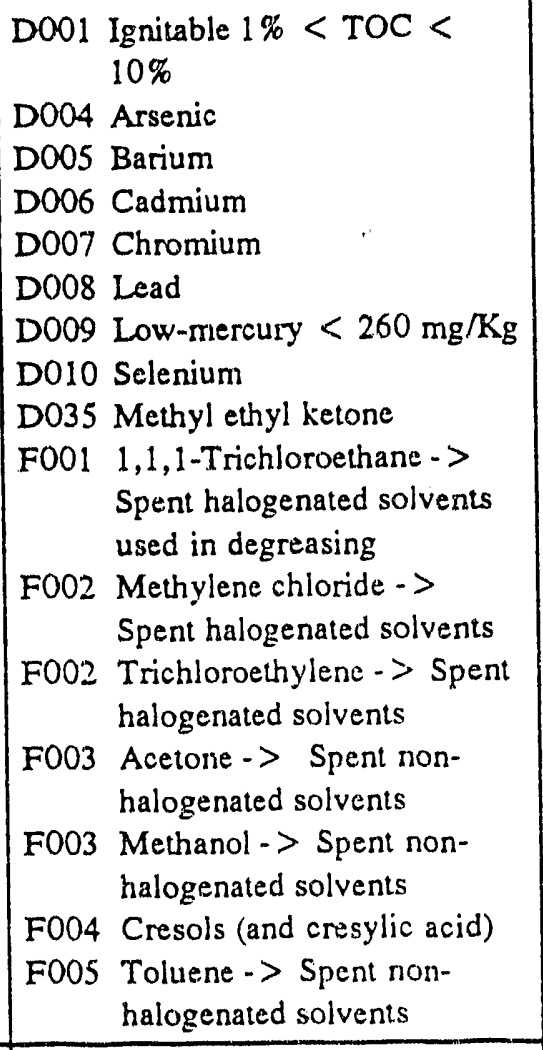 & $\begin{array}{l}\text { - Steam stripping (TT6600) and cartion adsorption(TT6650) } \\
\text { to remove the organics } f b \text { incineration (TT9000) of the } \\
\text { organics and precipitation (TT6200) of the characteristic } \\
\text { metals } f b \text { vitrification (TT11000) or stabilization } \\
\text { (TT12000) of the metal sludge, incinerator ash, and off- } \\
\text { gas system residues. }\end{array}$ \\
\hline $\begin{array}{l}\text { Resin beads contaminated } \\
\text { als }\end{array}$ & $0.8 \mathrm{~m}^{3}$ & $\begin{array}{l}\text { D005 Barium } \\
\text { D006 Cadmium } \\
\text { D007 Chromium } \\
\text { D008 Lead } \\
\text { D009 Low-mercury < } 260 \mathrm{mg} / \mathrm{Kg} \\
\text { D010 Selenium } \\
\text { D011 Silver }\end{array}$ & $\begin{array}{l}\text { - Incineration (TT9000) } f b \text { off-gas treatment (TT23000),fb } \\
\text { stabilization of incinerator ash and off-gas system residues } \\
\text { (TT12000) } \\
\text { - Stabilization (TT12000) } \\
\text { - Vitrification (TT9000) } f b \text { off-gas treatment (TT23000) } f b \\
\text { stabilization of off-gas system residues (TT12000) }\end{array}$ \\
\hline
\end{tabular}


Table 3. (continued).

\begin{tabular}{|c|c|c|c|c|}
\hline 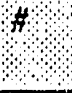 & Waste Stream D & Radiation & Name & Description \\
\hline G6 & Soils, Etc. & contact-handled & sons, ETC. & $\begin{array}{l}\text { Generic waste stream-Soils, slu } \\
\text { sludges contaminated wit organic } \\
\text { metals, arsenic, and PCBs. }\end{array}$ \\
\hline
\end{tabular}




\begin{tabular}{|c|c|c|c|}
\hline ।. & vonnual & EPA Codes & Potential Treatment Strategies, if necessary \\
\hline $\begin{array}{l}\text { ies, and } \\
\text {, characteristic }\end{array}$ & $12.0 \mathrm{~m}^{3}$ & $\begin{array}{l}\text { D004 Arsenic } \\
\text { D005 Barium } \\
\text { D006 Cadmium } \\
\text { D007 Chromium } \\
\text { D008 Lead } \\
\text { D009 Low-Mercury <260 mg/Kg } \\
\text { D010 Selenium } \\
\text { D011 Silver } \\
\text { D035 Methyl ethyl ketone } \\
\text { F001 1,1,1-Trichloroethane -> } \\
\text { Spent halogenated solvent } \\
\text { used in degreasing } \\
\text { F002 Methylene chloride -> } \\
\text { Spent halogenated solvents } \\
\text { F002 Trichloreethylene -> Spent } \\
\text { halogenated solvents } \\
\text { F003 Acetone - S Spent non- } \\
\text { halogenated solvents } \\
\text { F003 Methanol - > Spent non- } \\
\text { halogenated solvents } \\
\text { F003 Xylene - > Spent non- } \\
\text { halogenated solvents } \\
\text { F004 Cresols (and cresylic acid) } \\
\text { F005 Toluene - > Spent non- } \\
\text { halogenated solvents }\end{array}$ & $\begin{array}{l}\text { Vitrification (TT11000) } f b \text { incineration (TT9000) of off- } \\
\text { gases to destroy organics. } b \text { vitrification or solidification } \\
\text { (TT12000) of the incinerator and off-gas system residues } \\
\text { - Calcination (TT10100) } f b \text { incineration of the off-gases to } \\
\text { destroy organics to destroy the organics } f b \text { stabilization of } \\
\text { the incinerator ash and off-gas system residues (TT12000) } \\
\text { - Soil washing (TT16850) to remove organics and metals } \\
\text { from soil, } f b \text { steam stripping (TT6600) and carbon } \\
\text { adsorption (TT6650) to remove the organics, } f b \\
\text { incineration (TT9000) of the organics and precipitation } \\
\text { (TT6200) of the characteristic metals, } f b \text { stabilization } \\
\text { (TT12000) of the metal sludge }\end{array}$ \\
\hline
\end{tabular}


Table 4: Summary Table for Low-level Waste Stream Identification, Characterization, an

\begin{tabular}{|c|c|c|c|c|c|}
\hline H: & $\begin{array}{l}\text { Waste } \\
\text { Stream } \\
\text { ID }\end{array}$ & Waste Stream Description & $\begin{array}{l}\text { Annual } \\
\text { Volume } \\
(\mathrm{m} 3)\end{array}$ & Current Practice & $\begin{array}{l}\text { Annual } \\
\text { Curies }\end{array}$ \\
\hline 1 & $x_{21}$ & $\begin{array}{l}\text { ANY COMBINATION OF CLOTH, PAPER, } \\
\text { PLASTIC (NONHALO) AND WOOD }\end{array}$ & 1640 & $\begin{array}{l}75 \% \text { incineration } \\
12 \% \text { compaction } \\
9 \% \text { disposal-contact } \\
4 \% \text { sizing }\end{array}$ & $1.2 \mathrm{E} 2$ \\
\hline 2 & $\mathrm{X} 41$ & $\begin{array}{l}\text { ANY COMBINATION GLASS, } \\
\text { HALOGENATED PLASTIC, LAGGING, } \\
\text { LIQUID ABSORBERS METAL CHIPS, WIRE } \\
\text { \& ETC. }\end{array}$ & 577 & $\begin{array}{l}69 \% \text { compaction } \\
26 \% \text { disposal-contact } \\
2 \% \text { sizing } \\
2 \% \text { disposal-remote } \\
1 \% \text { incineration }\end{array}$ & $1.1 \mathrm{E}+$ \\
\hline 3 & M41 & METAL COMBINATION - ASSEMBLIES & 455 & $\begin{array}{l}66 \% \text { disposal-contact } \\
23 \% \text { sizing } \\
9 \% \text { compaction } \\
2 \% \text { disposal-remote }\end{array}$ & $1.9 \mathrm{E} 3$ \\
\hline 4 & P21 & PAPER AND/OR CLOTH & 236 & $\begin{array}{l}97 \% \text { incineration } \\
3 \% \text { disposal-contact }\end{array}$ & $2.27 \mathrm{EI}$ \\
\hline 5 & S71 & SOIL/GRAVEL/BRICK/CONCRETE RUBBLE & 218 & $100 \%$ disposal-contact & $6.1 \mathrm{El}$ \\
\hline 6 & M31 & METAL-STEEL, CARBON & 154 & $\begin{array}{l}68 \% \text { sizing } \\
30 \% \text { disposal-contact } \\
2 \% \text { compaction }\end{array}$ & 9.4 E 1 \\
\hline 7 & M33 & METAL - STEEL, STAINLESS & 140 & $\begin{array}{l}84 \% \text { sizing } \\
13 \% \text { disposal-contact } \\
3 \% \text { incineration }\end{array}$ & $1.6 \mathrm{E} 1$ \\
\hline 8 & R50 & $\begin{array}{l}\text { HOT FUEL EXAMINATION FACILITY- } \\
\text { SOUTH FACILITY MODIFICATION WASTE } \\
\text { STREAM }\end{array}$ & 122 & $100 \%$ disposal-contact & $1.7 \mathrm{E}$ \\
\hline
\end{tabular}




\section{Treatment Strategies.}

\begin{tabular}{|c|c|c|c|}
\hline $\begin{array}{l}\text { Low } \\
\text { Dose, } \\
\text { Rate, } \\
\text { (mRhr) }\end{array}$ & $\begin{array}{l}\text { High } \\
\text { Dose } \\
\text { Rate } \\
(\mathrm{mR} / \mathrm{hr})\end{array}$ & $\begin{array}{l}\text { Ave } \\
\text { Dose } \\
\text { Rate } \\
\text { (mR/hr) }\end{array}$ & $(b b=$ followed by, $<>=$ if necessary $)$ \\
\hline $0.0 \mathrm{E} 0$ & $1.7 \mathrm{E} 7$ & $1.5 \mathrm{E} 4$ & $\begin{array}{l}\text { - Sizing > (TT14000) } f b \text { incineration (TT9000) or thermal degradation/volatilization } \\
\text { (TT10000) } f b \text { off-gas treatment (TT23000) } f b \text { vitrification (TT11000) or stabilization } \\
\text { (TT12000) of the ash and off-gas system residues. } \\
\text { < sizing > (TT14000) } f b \text { volume reduction (TT8000) } f b \text { packaging (TT30200). }\end{array}$ \\
\hline $0.0 \mathrm{E} 0$ & $5.9 \mathrm{E} 7$ & 4.3 E 5 & $\begin{array}{l}\text { - } \quad \text { sizing > (TT14000) } f b \text { volume reduction (TT8000) } f b \text { packaging (TT30200) } \\
<\text { sizing > (TT14000) } f b \text { incineration (TT9000) or thermal degradation/volatilization } \\
\text { (TT10000) } f b \text { off-gas treatment (TT23000) } f b \text { vitrification (TT11000) or stabilization } \\
\text { (TT12000) of the ash and off-gas residues. }\end{array}$ \\
\hline $0.0 \mathrm{E} 0$ & $4.3 \mathrm{E} 7$ & 2.7 E 5 & $\begin{array}{l}\text { - } \quad \text { sizing > (TT14000) } f b \text { volume reduction (TT8000) } f b \text { packaging (TT30200). } \\
\quad<\text { sizing > (TT14000) } f b \text { metals recovery (TT15000) and reuse. } \\
\text { < sizing > (TT14000) } f b \text { vitrification (TT11000) } f b \text { off-gas treatment (TT23000). }\end{array}$ \\
\hline $0.0 \mathrm{E} 0$ & $4.5 E 3$ & $1.1 \mathrm{E} 2$ & $\begin{array}{l}\text { - < sizing > (TT14000) } f b \text { incineration (TT9000) or thermal degradation/volatilization } \\
\text { (TT10000) } f b \text { off-gas treatment (TT23000) } f b \text { vitrification (TT11000) or stabilization } \\
\text { (TT12000) of the ash and off-gas residues. } \\
\text { - < sizing > (TT14000) } f b \text { volume reduction (TT8000) } f b \text { packaging (TT30200) }\end{array}$ \\
\hline $0.0 \mathrm{E} 0$ & $3.6 \mathrm{E} 2$ & $9.0 \mathrm{E} 0$ & $\begin{array}{l}\text { package (TT30200). } \\
\text { separate (TT6000) } f b \text { packaging (TT30200) brick/concrete and vitrification (TT11000) } \\
\text { or stabilization (TT12000) of soil/gravel } f b<\text { off-gas treatment }>\text { (TT23000) }\end{array}$ \\
\hline $0.0 \mathrm{E} 0$ & $3.7 \mathrm{E} 4$ & $3.9 \mathrm{E} 2$ & $\begin{array}{l}\text { - sizing > (TT14000) } f b \text { volume reduction (TT8000) } f b \text { packaging (TT30200). } \\
\text { < sizing > (TT14000) } f b \text { metals recovery (TT15000) and reuse. } \\
\text { < sizing > (TT14000) } f b \text { vitrification }(T T 11000) f b \text { off-gas treatment }(T T 23000) \text {. }\end{array}$ \\
\hline $0.0 \mathrm{E} 0$ & 9.2 E 6 & $7.6 \mathrm{E} 4$ & $\begin{array}{l}\text { - } \quad \text { sizing > (TT14000) } f b \text { volume reduction (TT8000) } f b \text { packaging (TT30200). } \\
\text { < sizing > (TT14000) } f b \text { metals recovery (TT15000) and reuse. } \\
\text { - < sizing > (TT14000) } f b \text { vitrification (TT11000) } f b \text { off-gas treatment (TT23000). }\end{array}$ \\
\hline $0.0 \mathrm{E} 0$ & $1.6 \mathrm{E} 4$ & $7.7 \mathrm{E} 1$ & $\begin{array}{l}\text { - package (TT30200). } \\
\text { separation (TT6000) } f b \text { pacikaging (TT30200) non combustibles } f b \text { incineration } \\
\text { (TT9000) or thermal degradation/volatilization (TT10000) of the combustibles } f b \text { off- } \\
\text { gas treatment (TT23000) } f b \text { vitrification (TT11000) or stabilization (TT12000) of the } \\
\text { ash and off-gas residues }\end{array}$ \\
\hline
\end{tabular}


Table 4. (continued).

\begin{tabular}{|c|c|c|c|c|c|}
\hline$\pi$ & $\begin{array}{l}\text { Waste } \\
\text { Stream } \\
\text { ID }\end{array}$ & wast Stream Description & Annual & Current Practice & Annual \\
\hline 9 & $x 80$ & $\begin{array}{l}\text { NRF/ECF/WERF WASTE ONLY - } 20 \% \\
\text { CARBON STEEL, 30\% STAINLESS STEEL, } \\
10 \% \text { METAI COMBINATION ASSEMBLIES, } \\
\text { 40\% COMBINED WTTH GLASS, } \\
\text { HALOGENATED PLASTIC, LAGGING, } \\
\text { LIQUID ABSORBERS, METALLIC CHIPS, } \\
\text { WIRE, ETC. }\end{array}$ & 79 & $100 \%$ compaction & $2.6 \mathrm{E} 0$ \\
\hline 10 & $x 22$ & $\begin{array}{l}\text { NRF/ECF WASTE ONLY - } 60 \% \text { PAPER } \\
\text { AND/OR CLOTH, } 30 \% \text { NON- } \\
\text { HALOGENATED PLASTIC, AND } 10 \% \\
\text { WOOD }\end{array}$ & 75 & $100 \%$ incineration & $8.0 \mathrm{E}-2$ \\
\hline 11 & $x 61$ & ANY COMBINATION OF FILTERS & 62 & $\begin{array}{l}62 \% \text { compaction } \\
26 \% \text { disposal-contact } \\
12 \% \text { incineration }\end{array}$ & $5.6 \mathrm{EC}$ \\
\hline 12 & I21 & $\begin{array}{l}\text { ION EXCHANGE RESIN IN METAL } \\
\text { CONTAINMENT }\end{array}$ & 57 & $\begin{array}{l}97 \% \text { disposal-contact } \\
3 \% \text { disposal-remote }\end{array}$ & $1.1 \mathrm{E} ?$ \\
\hline 13 & M83 & $\begin{array}{l}\text { NRF/ECF ONLY - 20\% CARBON STEEL, } \\
30 \% \text { STAINLESS STEEL, 10\% METAL } \\
\text { COMBINATION ASSEMBLIES, } 40 \% \text { ANY } \\
\text { COMBINATION GLASS, HALOGENATED } \\
\text { PLASTIC, LAGGING, LIQUID ABSORBERS, } \\
\text { METAL CHIPS, WIRE AND ETC. }\end{array}$ & 56 & $100 \%$ disposal-contact & $1.9 \mathrm{E} 1$ \\
\hline
\end{tabular}




\begin{tabular}{|c|c|c|c|}
\hline $\begin{array}{l}\text { Low } \\
\text { Dose } \\
\text { Rate } \\
\text { (mR/hr) }\end{array}$ & $\begin{array}{l}\text { High } \\
\text { Dose } \\
\text { Rate } \\
\text { (mR/hr) }\end{array}$ & $\begin{array}{l}\text { Ave. } \\
\text { Dose } \\
\text { Rate, } \\
\text { (mR/hr) }\end{array}$ & $f b=$ followed by,$<>=$ if necessary) \\
\hline $1.0 \mathrm{E} 0$ & $9.5 \mathrm{E} 2$ & $7.3 \mathrm{E} 1$ & $\begin{array}{l}\text { < sizing }>\text { (TT14000) } f b \text { waste segregation (TT6000) } f b \text { metals recovery (TT15000) or } \\
\text { vitrification (TT11000) } f b \text { off-gas treatment (TT23000) of the metal. For combustibles, } \\
\text { incineration (TT9000) or thermal degradation/volatilization (TT10000) } f b \text { off-gas } \\
\text { treatment (TT23000) } f b \text { vitrification (TT11000) or stabilization (TT12000) of the ash } \\
\text { and off-gas residuals. For remaining media, volume reduction (TT8000) } f b \text { packaging } \\
\text { (TT30200). } \\
\text { < sizing > (TT14000) } f b \text { volume reduction (TT8000) } f b \text { packaging (TT30200). }\end{array}$ \\
\hline $3.0 \mathrm{E} 0$ & $3.3 \mathrm{E} 1$ & $1.4 \mathrm{E} 1$ & $\begin{array}{l}\text { - < sizing > (TT14000) } f b \text { incineration (TT9000) or thermal degradation/volatilization } \\
\text { (TT10000) } f b \text { off-gas treatment (TT23000) } f b \text { vitrification (TT11000) or stabilization } \\
\text { (TT12000) of the ash and off-gas residues. } \\
\text { - < sizing > (TT14000) } f b \text { volume reduction (TT8000) fb packaging (TT30200) }\end{array}$ \\
\hline $0.0 \mathrm{EO}$ & $1.0 \mathrm{E} 3$ & $5.0 \mathrm{E} 1$ & $\begin{array}{l}\text { - compact (TT8100) fitters } f b \text { <evaporation (TT4000) } f b \text { stabilization (TT12000) or } \\
\text { liquid incineration (TT9325)> of liquids. } \\
\text { - sizing > (TT14000) of filters } f b \text { incineration (TT9000) } f b \text { off-gas treatment } \\
\text { (TT23000) } f b \text { stabilization (TT12000) or vitrification (TT11000) of the ash and off-gas } \\
\text { system residues } f b \text { <separation of metals from ash } f b \text { melul recovery > (TT15000). }\end{array}$ \\
\hline $2.0 \mathrm{E} 0$ & 3.4 E 5 & $1.1 E 4$ & 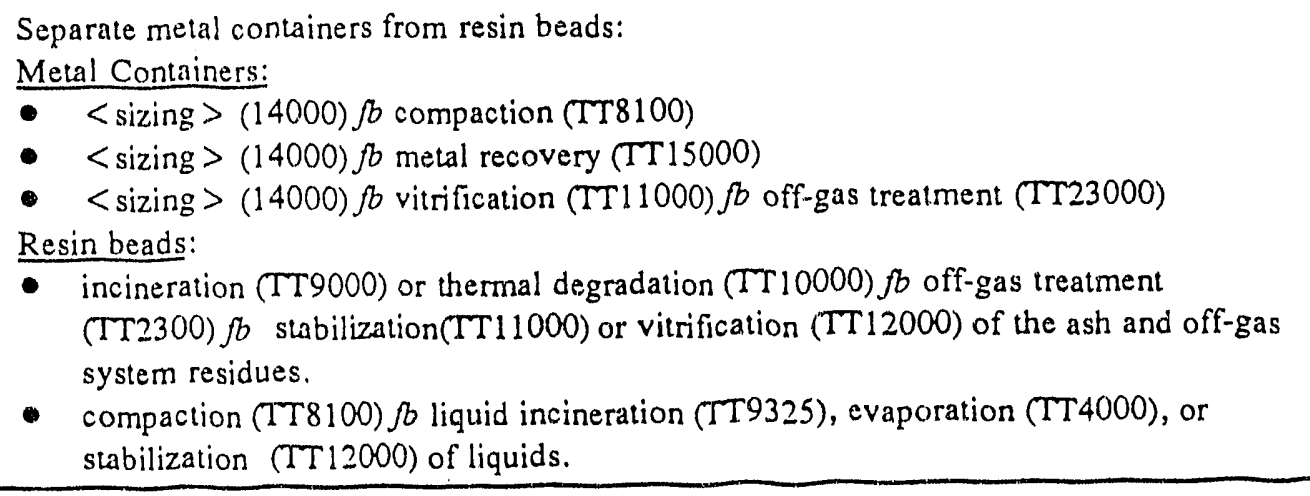 \\
\hline $1.0 \mathrm{E} 0$ & $1.3 E 3$ & $1.1 \mathrm{E} 2$ & 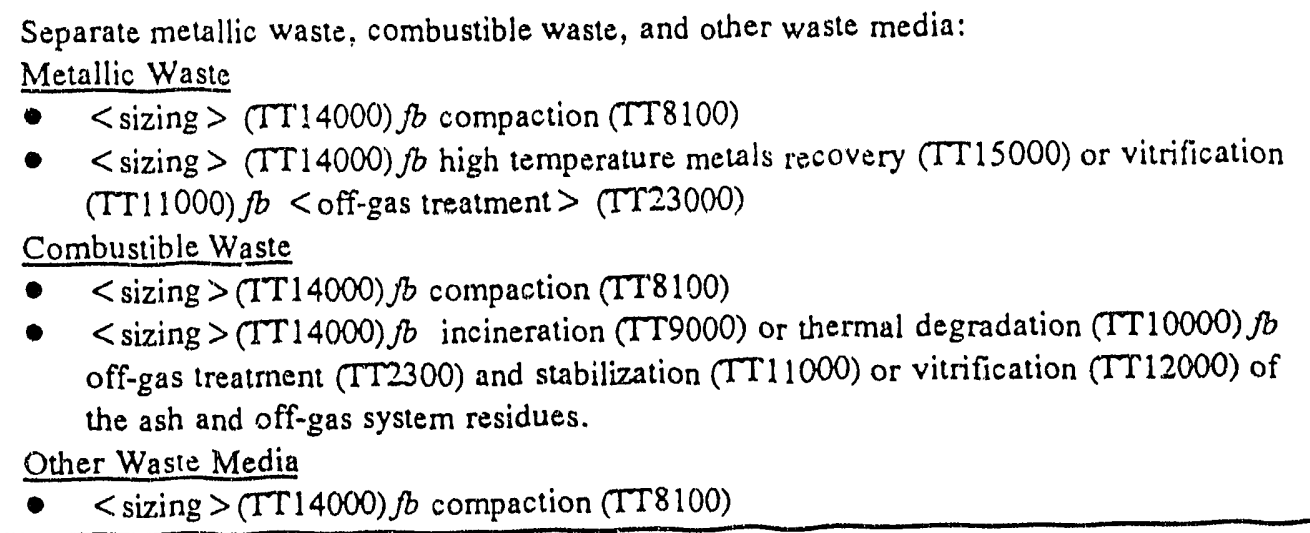 \\
\hline
\end{tabular}


Table 4. (continued).

\begin{tabular}{|c|c|c|c|c|c|}
\hline 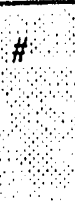 & $\begin{array}{l}\text { Waste } \\
\text { Stream } \\
\text { ID }\end{array}$ & Waste Stream Description & $\begin{array}{l}\text { Annual } \\
\text { Volume } \\
\text { (m3) }\end{array}$ & Current Practicr & Annual \\
\hline 14 & $\times 31$ & $\begin{array}{l}\text { ANY COMBINATION OF FERROUS AND } \\
\text { NONFERROUS METAL ARTICLES }\end{array}$ & 39 & $\begin{array}{l}58 \% \text { disposal-contact } \\
31 \% \text { sizing } \\
7 \% \text { compaction } \\
4 \% \text { incineration }\end{array}$ & $1.1 \mathrm{E}-2$ \\
\hline 15 & A34 & ASH, SOLIDIFIED IN CONCRETE & 35 & not applicable & $9.2 \mathrm{E}-2$ \\
\hline 16 & $S 72$ & CONCRETE STRUCTURAL COMPONENTS & 34 & $100 \%$ disposal-contact & $3.7 \mathrm{E}-3$ \\
\hline 17 & M84 & $\begin{array}{l}\text { NRF/ECF/WERF WASTE ONLY - } 30 \% \\
\text { CARBON STEEL, 50\% STAINLESS STEEL, } \\
20 \% \text { METAL COMBINATION ASSEMBLIES }\end{array}$ & 28 & $\begin{array}{l}98 \% \text { sizing } \\
2 \% \text { disposal-contact }\end{array}$ & 5.2 E-3 \\
\hline 18 & C61 & CORE STRUCTURAL PARTS & 25 & $100 \%$ disposal-remote & $4.2 \mathrm{E} 4$ \\
\hline 19 & F21 & FILTER - HEPA & 18 & $\begin{array}{l}67 \% \text { sizing } \\
33 \% \text { disposal-contact }\end{array}$ & $1.9 \mathrm{EO}$ \\
\hline 20 & M61 & $\begin{array}{l}\text { METAL CHIPS OR MISCELLANEOUS } \\
\text { SMALL METAL OBJECTS }\end{array}$ & 21 & $\begin{array}{l}63 \% \text { disposal-contact } \\
37 \% \text { compaction }\end{array}$ & $2.4 \mathrm{E}-1$ \\
\hline 21 & W31 & WOOD & 17 & $\begin{array}{l}83 \% \text { incineration } \\
11 \% \text { sizing } \\
6 \% \text { disposal-contact }\end{array}$ & $9.6 \mathrm{E}-3$ \\
\hline 22 & $\mathrm{~F} 22$ & FILTER - OTHER THAN HEPA & 14 & $100 \%$ compaction & $8.4 \mathrm{E}-?$ \\
\hline 23 & M71 & METAL SIZED BY WERF CARBON STEEL & 16 & not applicable & $9.9 \mathrm{E}$ \\
\hline 24 & B22 & $\begin{array}{l}\text { BIOLOGICAL WASTE - FECES, } \\
\text { VEGETATION }\end{array}$ & 13 & $100 \%$ disposal-contact & $2.3 \mathrm{E}-$ \\
\hline 25 & A61 & $\begin{array}{l}\text { RADIOACTIVE CONTAMINATED } \\
\text { ASBESTOS }\end{array}$ & 12 & $100 \%$ disposal-contact & $3.6 \mathrm{E}-$ \\
\hline
\end{tabular}




\begin{tabular}{|c|c|c|c|}
\hline $\begin{array}{l}\text { Low } \\
\text { Dose. } \\
\text { Rate. } \\
\text { (mR/hr) }\end{array}$ & $\begin{array}{l}\text { High } \\
\text { Dose } \\
\text { Rate } \\
\text { (nR/hr) }\end{array}$ & $\begin{array}{l}\text { Ave. } \\
\text { Dose } \\
\text { Rate } \\
(\mathrm{mR} / \mathrm{hr})\end{array}$ & $(B)=$ followed by $<>>$ = if necessary $)$ \\
\hline $0.0 \mathrm{E} 0$ & $1.1 \mathrm{E} 1$ & $2.0 \mathrm{EO}$ & $\begin{array}{l}\text { - } \quad \text { sizing }>f b \text { packaging (TT30200) } \\
\text { - } \quad<\text { sizing }>f b \text { compaction (TT8100) } \\
\text { - } \quad \text { sizing }>(\text { TT14000) } f b \text { high temperature metals recovery (TT15000) } \\
\text { - } \text { sizing }>\text { (TT14000) } f b \text { vitrification (TT11000) jb off-gas treatment (TT23000) }\end{array}$ \\
\hline $1.0 \mathrm{E} 0$ & $2.0 \mathrm{E} 1$ & $6.0 \mathrm{E} 0$ & not applicable-this is a secondary waste stream \\
\hline $1.0 \mathrm{E} 0$ & $2.5 \mathrm{E} 1$ & $2 \mathrm{EO}$ & - <package > (TT30200) \\
\hline $1.0 \mathrm{E} 0$ & $5.0 \mathrm{EO}$ & $2.0 \mathrm{EO}$ & $\begin{array}{l}\text { - < sizing > (TT 14000) } f b \text { compaction (TT8100) } f b \text { <packaging > (TT30200) } \\
\text { - <izing > (TT } 14000) f b \text { high temperature metals re:overy (TT15000) } \\
\text { < sizing > (14000) } f b \text { vitrification (TT1100'J) } f b \text { off-gas treatment (TT23000) }\end{array}$ \\
\hline $2.6 \mathrm{E} 4$ & $5.9 \mathrm{E} 7$ & $1.0 \mathrm{E} 7$ & - < sizing > (TT 14000) fb packaging (TT30200) \\
\hline $0.0 \mathrm{EO}$ & $3.7 \mathrm{E} 2$ & $3.2 \mathrm{E} 1$ & 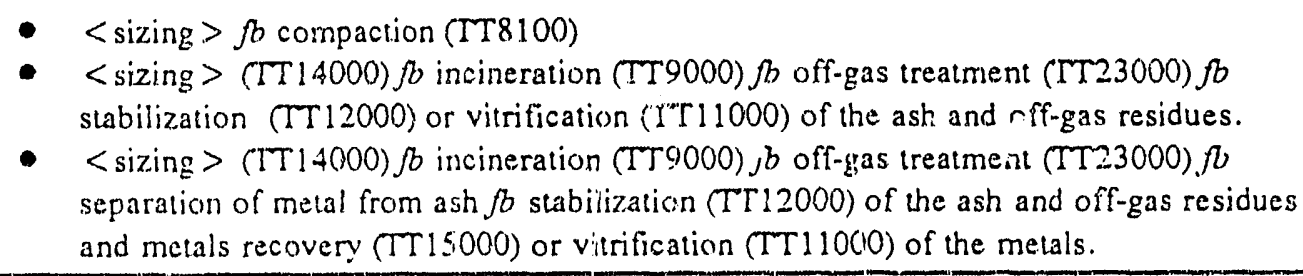 \\
\hline $0.0 \mathrm{E} 0$ & $9.0 \mathrm{E} 4$ & $2.3 \mathrm{E} 2$ & $\begin{array}{l}\text { - compaction (TT8100) } \beta b \text { packaging (TT30200) } \\
\text { high-temperature metals recovery (TT15000) fo off-gas treatment (TT23000) and } \\
\text { stabilization of secondary waste streams (TT12000) } \\
\text { vitrification (TT11000) fb off-gas treatment (TT23000) and stabilization of secondary } \\
\text { waste streams (TT12000) }\end{array}$ \\
\hline $0.0 \mathrm{E} 0$ & $8.0 \mathrm{El}$ & $8.0 \mathrm{EO}$ & $\begin{array}{l}\text { - < sizing > (TT14000) } f b \text { incineration (TT9000) } f b \text { off gas lireatment (TT23000) } f b \\
\text { solidification(TT12000) or vitrification (TT11000) of ast and off-gas system residues } \\
\text { - < sizing }>f b \text { compaction (TT810(1) }\end{array}$ \\
\hline $1.0 \mathrm{E} 0$ & $7.0 \mathrm{El}$ & $2.0 \mathrm{EI}$ & 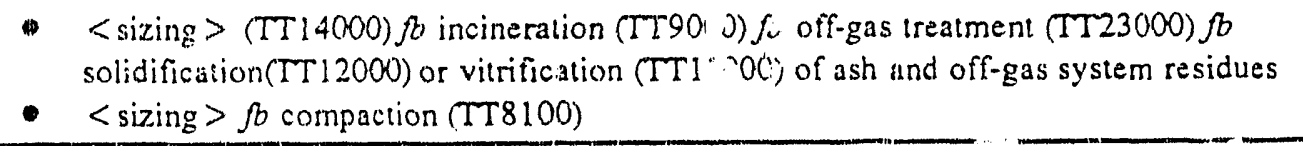 \\
\hline $1.0 \mathrm{EO}$ & $1.4 E^{2}$ & $8.0 \mathrm{EO}$ & not applicable - this is a secondary waste strearn \\
\hline $0.0 \mathrm{EO}$ & $0.0 \mathrm{E} 0$ & $0.0 \mathrm{EO}$ & $\begin{array}{l}\text { - incineration (TT9000) fb off-gas treatrnent (TT23000) fb solidification(TT12000) or } \\
\text { vitrification (TT11000) of the as/2 and off-gas system residues. }\end{array}$ \\
\hline $0.0 \mathrm{EO}$ & $8.0 \mathrm{E} 2$ & $3.8 \mathrm{E} 1$ & 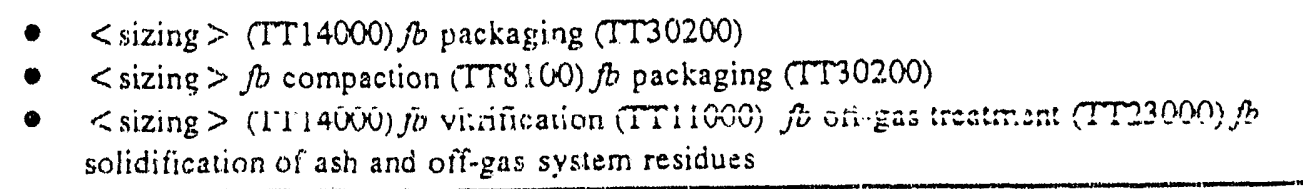 \\
\hline
\end{tabular}


Table 4. (continued).

\begin{tabular}{|c|c|c|c|c|c|}
\hline$\#$ & $\begin{array}{l}\text { Waste } \\
\text { Stream } \\
\text { ID }\end{array}$ & Waste Stream Description & $\begin{array}{l}\text { Annual } \\
\text { Volume } \\
\text { (m3) }\end{array}$ & Current Practice & $\begin{array}{l}\text { Annual: } \\
\text { Curies }\end{array}$ \\
\hline 26 & $C 75$ & $\begin{array}{l}\text { NRF/ECF ONLY - } 70 \% \text { CORE } \\
\text { STRUCTURAL PARTS, 10\% CORE } \\
\text { INSTRUMENTATION, 20\% COMBINATION } \\
\text { OF GLASS, HALOGENATED PLASTIC, } \\
\text { LAGGING, LIQUID ABSORBENTS, } \\
\text { METALLIC CHIPS, WIRE, ETC. 55-TON } \\
\text { CASK I }\end{array}$ & 11 & $100 \%$ disposal-remote & $2.0 \mathrm{E} 4$ \\
\hline 27 & M.1 1 & METAL - ALUMINUM & 11 & $\begin{array}{l}55 \% \text { disposal-contact } \\
45 \% \text { sizing }\end{array}$ & $2.0 \mathrm{E}-1$ \\
\hline 28 & 122 & $\begin{array}{l}\text { ION EXCHANGE RESIN IN CONCRETE } \\
\text { CONTAINMENT }\end{array}$ & 8 & $\begin{array}{l}52 \% \text { disposal-remote } \\
48 \% \text { disposal-contact }\end{array}$ & $6.8 \mathrm{E} 2$ \\
\hline 29 & $\$ 41$ & SLUDGE & 8 & $100 \%$ disposal-contact & $2.1 \mathrm{E}-3$ \\
\hline 30 & $\mathrm{x} 51$ & $\begin{array}{l}\text { ANY COMBINATION OF PAVING, } \\
\text { ROOFING, SOIL/GRAVEL. BRICK \& } \\
\text { CONCRETE RUBBLE }\end{array}$ & 6 & $100 \%$ disposal-contact & $4.5 \mathrm{E}-1$ \\
\hline 31 & $\mathrm{P} 31$ & $\begin{array}{l}\text { PAVING (E.G., ASPHAL,T AND } \\
\text { CONCREIE) }\end{array}$ & 6 & $100 \%$ disposal-contact & $5.0 \mathrm{E}-4$ \\
\hline 32 & M73 & METAL SIZED BY WERF - NONFERROUS & 6 & not applicable & $6.4 \mathrm{E}-3$ \\
\hline 33 & $\mathrm{R} 21$ & ROOFWNG (E.G., ASPHALT SHINGLES) & 6 & $100 \%$ disposal-contact & $3.1 \mathrm{E}-2$ \\
\hline
\end{tabular}




\begin{tabular}{|c|c|c|c|}
\hline $\begin{array}{l}\text { Low } \\
\text { Dose } \\
\text { Kate } \\
(\mathrm{mR} / \mathrm{hr})\end{array}$ & $\begin{array}{l}\text { High } \\
\text { Dose, } \\
\text { Rate } \\
(\mathrm{mR} / \mathrm{hr})\end{array}$ & $\begin{array}{l}\text { Ave. } \\
\text { Dose } \\
\text { Rate, } \\
(\mathrm{mR} / \mathrm{hr})\end{array}$ & $\beta b=$ Pollowed by, $<>=$ if necessary) \\
\hline $1.8 \mathrm{E} 6$ & $1.4 \mathrm{E} 7$ & $6.2 \mathrm{E} 6$ & - < sizing $>($ TT 14000) $f b<$ compaction $>(T T 8100) f b$ packaging (TT30200) \\
\hline $0.0 \mathrm{E} 0$ & $9.0 \mathrm{E} 3$ & $3.2 \mathrm{E} 2$ & $\begin{array}{l}\text { - < sizing > (TT14000) } f b \text { compaction (TT8100) } f b \text { packaging (TT30200) } \\
\text { - < sizing > (TT14000) } f b \text { high ternperature metals recovery (TT15000) } \\
\text { < sizing > (14000) fb vitrification (TT11000) } f b \text { off-gas treatment (TT23000) }\end{array}$ \\
\hline $3.0 \mathrm{El}$ & $3.7 \mathrm{E} 4$ & $1.1 \mathrm{E} 4$ & - package (TT30200) \\
\hline $1.0 \mathrm{EO}$ & $1.0 \mathrm{E} 0$ & $1.0 \mathrm{E} 0$ & $\begin{array}{l}\text { - thermal drying (TTO350) } f b \text { vitrification (TT11000) or stabilization (TT12000) } f b \\
\text { <off-gas treatment > (TT23000) } \\
\text { incireration (TT9000) or thermal degradation/ volatilization (TT10000) } f b \text { off-gas } \\
\text { treatment (TT23000) } f b \text { vitrification (TT11000) or stabilization (TT12000) of the ash } \\
\text { and off-gas system residues } \\
\text { filtration (TT1000) or centrifugation (TT6300) } f b \text { iacineration }(T T 9000) \text { or thermal } \\
\text { degradation/volatilization (TT10000) } f b \text { off-gas treatment (TT23000) } f b \text { vitrification } \\
\text { (TT11000) or stabilization (TT12000) of the ash and off-gas residuals for solids. } \\
\text { Stabilization (TT12000) of the liquid portion of the waste. } \\
\text { - Stabilization (TT12000) or vitrification (TT11000) } f b<\text { off-gas treatment > (TT23000) }\end{array}$ \\
\hline $0.0 \mathrm{EO}$ & $3.5 \mathrm{E} 2$ & $3.5 \mathrm{E} 1$ & $\begin{array}{l}\text { - sizing > (TT14000) } f b \text { packaging (TT3020) } \\
\text { < sizing > (TT14000) } f b \text { separation (TT6000) } f b \text { packaging (TT30200) of the brick } \\
\text { and concrete and incineration (TT9000), vitrification (TT1 1000), or stabilization } \\
\text { (TT12000) of the soil, gravel, asphalt, and roofing } f b<\text { <ff-gas treatment > } \\
\text { (TT23000) and < vitrification or stabilization> of products of combustion and off-gas } \\
\text { residues. }\end{array}$ \\
\hline $0.0 \mathrm{E} 0$ & $0.0 \mathrm{E} 0$ & $0.0 \mathrm{EO}$ & $\begin{array}{l}\text { - sizing > (TT14000) } f b \text { packaging (TT30200) } \\
\text { < sizing > (Ti14000) } f b \text { separation } f b \text { packaging (TT30200) of the concrete and } \\
\text { incineration (TT9000), vitrification (TT11000), or stabilization (TT12000) of the } \\
\text { asphalt } f b<\text { < off-gas treatment > (TT23000) fb < vitrification or solidtrication> of the } \\
\text { ash and off-gas residues. }\end{array}$ \\
\hline $0.0 \mathrm{EO}$ & $1.0 \mathrm{EO}$ & $0.0 \mathrm{E} 0$ & not applicable - this is a secondary waste stream \\
\hline $1.0 \mathrm{EO}$ & $1.0 \mathrm{EO}$ & $1.0 \mathrm{EO}$ & 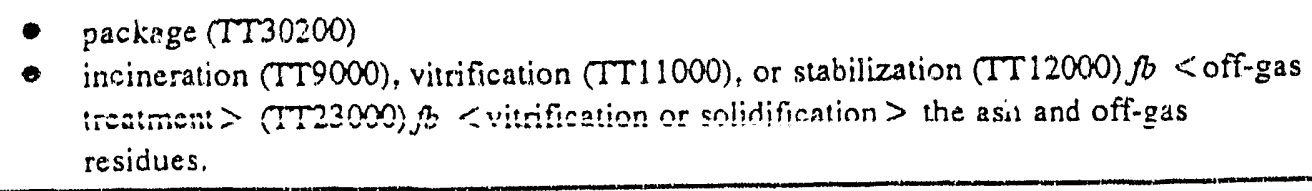 \\
\hline
\end{tabular}


Table 4. (continued).

\begin{tabular}{|c|c|c|c|c|c|}
\hline th & $\begin{array}{l}\text { Waste. } \\
\text { Stream } \\
\text { ID }\end{array}$ & Waste Stream Description & $\begin{array}{l}\text { Annual: } \\
\text { Volume } \\
\text { (m3) }\end{array}$ & Current Practice: & Annual \\
\hline 34 & $\mathrm{C} 62$ & CORE SUBASSEMBLY PARTS & 6 & $\begin{array}{l}93 \% \text { disposal-remote } \\
7 \% \text { disposal-contact }\end{array}$ & 2.3 E 5 \\
\hline 35 & E21 & EVAPORATION DRUM (E.G., SHADE) & 5 & $100 \%$ disposal-contact & $1.6 \mathrm{E}-1$ \\
\hline 36 & A24 & $\begin{array}{l}\text { ABSORBED LIQUIDS, NONCOMBUSTIBLE- } \\
\text { DIATTOMACEOUS EARTH (E.G. KITTY } \\
\text { LITTER) }\end{array}$ & 5 & $100 \%$ disposal-contact & $2.7 \mathrm{E}-1$ \\
\hline 37 & $x^{8} 81$ & $\begin{array}{l}\text { NRF/ECF WASTE ONLY - } 90 \% \text { RESIN } \\
\text { CONTAINERS AND 10\% STARLESS } \\
\text { STEEL RESIN MODULE }\end{array}$ & 5 & $100 \%$ disposal-contact & $3.2 \mathrm{E} \mathrm{I}$ \\
\hline 38 & M72 & $\begin{array}{l}\text { METAL SIZED BY WERF STAINLESS } \\
\text { STEEL }\end{array}$ & 5 & not applicable & $2.2 \mathrm{E} 0$ \\
\hline 39 & s51 & $\begin{array}{l}\text { HFEF/NORTH PROCESS AND } \\
\text { MAINTENANCE WASTE } \\
\text { STRE.AM,BUILDING } 785\end{array}$ & 4 & $100 \%$ disposal-contact & $1.2 \mathrm{EO}$ \\
\hline
\end{tabular}




\begin{tabular}{|c|c|c|c|}
\hline $\begin{array}{l}\text { Low } \\
\text { Dose } \\
\text { Rate } \\
(\mathrm{mR} / \mathrm{hr})\end{array}$ & $\begin{array}{l}\text { High } \\
\text { Dose } \\
\text { Rate } \\
\text { (mR/hr) }\end{array}$ & $\begin{array}{l}\text { Ave. } \\
\text { Dose } \\
\text { Rate } \\
(\mathrm{mR} / \mathrm{hr})\end{array}$ & $(f b=$ followed by,$<>=$ if necessary) \\
\hline $1.8 \mathrm{E} 6$ & $1.4 \mathrm{E} 7$ & $6.2 \mathrm{E} 6$ & - package (TT30200) \\
\hline $4.0 \mathrm{E} 0$ & $4.0 \mathrm{E} 1$ & $8.0 \mathrm{EO}$ & - package (TT30200) \\
\hline $0.0 \mathrm{E} 0$ & $1.4 \mathrm{E} 4$ & $4.4 \mathrm{E} 2$ & $\begin{array}{l}\text { Absorbed Aqueous Liquids: } \\
\text { stabilization (TT12000) } \\
\text { drying (TT6350) } f b \text { stabilization (TT12000) } \\
\text { vitrification (TT11000) } f b \text { off-gas treatment (TT23000) } \\
\text { Absorbed Organic Liquids: } \\
\text { incineration (TT9000) or thermal degradation/volatilization (TT10000) fb off-gas } \\
\text { treatment (TT23000) } f b \text { vitrification (TT11000) or stabilization (TT12000) of the ash } \\
\text { and off-gas residuals. } \\
\text { drying (TT6350) } f b \text { stabilization (TT12000) } \\
\text { - vitrification (TT11000) } f b \text { off-gas treatment (TT23000) }\end{array}$ \\
\hline $2.0 \mathrm{EO}$ & $3.0 \mathrm{E} 3$ & $1.0 \mathrm{E3}$ & $\begin{array}{l}\text { Separate resin and activated carbon from steel containers. } \\
\text { Steel Containers } \\
\text { package (TT30200) } \\
\text { < sizing > } f b \text { volume reduction (TT8000) } f b \text { packaging (TT30200) } \\
\text { < sizing > } f b \text { recovery and reuse of the metal (TT15000) } \\
\text { < sizing > } f b \text { vitrification (TT11000) } f b \text { off-gas treatment (TT23000) } \\
\text { Resin and Activated Carbon } \\
\text { package (TT30200) } \\
\text { incineration (TT9000) or thermal degradation/volatilization (TT10000) } f b \text { off-gas } \\
\text { treatment (TT23000) } f b \text { vitrification (TT11000) or stabilization (TT12000) of the ash } \\
\text { and off-gas residuals. } \\
\text { Compaction (TT8100) } f b \text { stabilization (TT12000) or liquid incineration (TT9325) for } \\
\text { the resulting liquid and incineration (TT9000), thermal degradation/volatilization } \\
\text { (Tr10000), or vittification (TT11000) } f b \text { off-gas treatment (TT23000) for the resin } \\
\text { beads. }\end{array}$ \\
\hline $1.0 \mathrm{E} 0$ & $2.7 \mathrm{E} 2$ & $2.6 \mathrm{El}$ & not applicable - this is a secondary waste stream \\
\hline $1.5 \mathrm{E} \mathrm{I}$ & $4.9 \mathrm{E} 2$ & $1.5 \mathrm{E} 2$ & $\begin{array}{l}\text { < sizing > (TT14000) } f b \text { separation: } \\
\text { Combustible Waste } \\
\text { incineration (TT9000) or thermal degradation/volatilization (TT10000) } f b \text { off-gas } \\
\text { treatment (TT23000) } f b \text { vitrification (TT11000) or stabilization (TT12000) of the ash } \\
\text { and off-gas residuals. } \\
\text { compaction (TT8100) } f b \text { packaging (TT30200) } \\
\text { Metallic Waste } \\
\text { virification (TT11000) fb off-gas treatment (TT23000) } \\
\text { metai recovery (TI } 3000 \text { j } \\
\text { compaction (TT8100) } f b \text { packaging (TT30200) }\end{array}$ \\
\hline
\end{tabular}


Table 4. (continued).

\begin{tabular}{|c|c|c|c|c|c|}
\hline$\#$ & $\begin{array}{c}\text { Waste } \\
\text { Stream } \\
\mathrm{ID}\end{array}$ & Waste Stream Description & $\begin{array}{l}\text { Annual } \\
\text { Volume } \\
\text { (m3) }\end{array}$ & Current Practice & Annual \\
\hline 40 & $\mathrm{~L} 20$ & $\begin{array}{l}\text { L\&O LABORATORY BLDG } 752 \\
\text { ANALYTICAL LABORATORY WASTE } \\
\text { STREAM }\end{array}$ & 4 & $100 \%$ disposal-contact & $1.1 \mathrm{E} 1$ \\
\hline 41 & F31 & FILTER-LIQUID & 3 & $100 \%$ disposal-contact & $1.4 \mathrm{E}-1$ \\
\hline 42 & P41 & PLASTIC - NONHALOGENATED & 3 & $\begin{array}{l}88 \% \text { incineration } \\
12 \% \text { disposal-contact }\end{array}$ & $1.2 \mathrm{E}-2$ \\
\hline 43 & $\mathrm{P} 42$ & PLASTIC - HALOGENATED & 1 & $100 \%$ compaction & $5.4 E-4$ \\
\hline 44 & W21 & WIRING AND WIRING DEVICES & 1 & $100 \%$ iisposal-contact & $4.8 \mathrm{E}-2$ \\
\hline 45 & A31 & ASH,UNSOLIDIFIED & 1 & not applicable & $7.0 \mathrm{E}-3$ \\
\hline 46 & $s 75$ & CEMENTED ZR FINES & 0.5 & $100 \%$ disposal-contact & $1.6 \mathrm{EC}$ \\
\hline 47 & M43 & METAL - CUT UP GLOVE BOXES & 0.4 & $100 \%$ disposal-contact & $6.3 \mathrm{E}-5$ \\
\hline
\end{tabular}




\begin{tabular}{|c|c|c|c|}
\hline $\begin{array}{l}\text { Low } \\
\text { Dose } \\
\text { Rate } \\
\text { (mR/hr) }\end{array}$ & $\begin{array}{l}\text { Hight } \\
\text { Dose, } \\
\text { Rate, } \\
\text { (mR/hr) }\end{array}$ & $\begin{array}{l}\text { Ave. } \\
\text { Dose. } \\
\text { Rate } \\
\text { (mR/hr) }\end{array}$ & $f b=$ followed by $<>$ - if necessary) \\
\hline $0.0 \mathrm{E} 0$ & $1.2 \mathrm{E} 4$ & $1.2 \mathrm{E} 3$ & $\begin{array}{l}\text { < Sizing > (TT14000) } f b \text { separation } \\
\text { Combustible Media } \\
\text { incineration (TT9000) or thermal degradation/volatilization (TT10000) } f b \text { off-gas } \\
\text { treatment (TT23000) } f b \text { vitrification (TT11000) or stabilization (TT12000) of the ash } \\
\text { and off-gas residuals. } \\
\text { compaction (TT8100) } f b \text { packaging (TT30200) } \\
\text { Metallic Waste } \\
\text { - vitrification (TT11000) } f b \text { off-gas treatment (TT23000) } \\
\text { metal recovery (TT15000) } \\
\text { Non-combustible Media } f b \text { packaging (TT30200) } \\
\text { vitrification (TT11000) } f b \text { off-gas treatment (TT23000) or stabilization (TT12000) } \\
\text { compaction(TT8100) } f b \text { packaging (TT30200) } \\
\text { Non irradiated Fuel Samples } \\
\text { package (TT30200) }\end{array}$ \\
\hline $3.5 \mathrm{E} 1$ & $1.0 \mathrm{E} 3$ & $3.7 \mathrm{E} 2$ & $\begin{array}{l}\text { - < sizing > (TT14000) } f b \text { incineration (TT9000) or thermal degradation/volatilization } \\
\text { (TT10000) } f b \text { off-gas treatment (TT23000) } f b \text { vitrification (TT11000) or stabilization } \\
\text { (TT12000) of the ash and off-gas residuals. } \\
\text { < sizing > (TT14000) } f b \text { compaction (TT8100) } f b \text { stabilization (TT12000) for the } \\
\text { resulting liquid and incineration (TT9000) for the organic liquids. }\end{array}$ \\
\hline $0.0 \mathrm{E} 0$ & $7.0 \mathrm{E} 1$ & $2.0 \mathrm{EO}$ & $\begin{array}{l}\text { - sizing }>\text { (TT14000) } f b \text { incineration (TT9000) or thermal degradation/volatilization } \\
\text { (TT10000) } f b \text { off-gas treatment (TT23000) } f b \text { vitrification (TT11000) or stabilization } \\
\text { (TT12000) of the ash and off-gas residuals. } \\
\text { < sizing }>f b \text { volume reduction (TT8000) } f b \text { packaging (TT30200) }\end{array}$ \\
\hline $1.0 \mathrm{EO}$ & $5.0 \mathrm{E} 1$ & $9.0 \mathrm{E} 0$ & $\begin{array}{l}\text { - < sizing > (TT14000) } f b \text { incineration (TT9000) or thermal degradation/volatilization } \\
\text { (TT10000) } f b \text { off-gas treatment (TT23000) } f b \text { vitrification (TT11000) or stabilization } \\
\text { (TT12000) of the ash and off-gas residuals. } \\
\text { - < sizing }>f b \text { volume reduction (TT8000) } f b \text { packaging (TT30200) }\end{array}$ \\
\hline $0.0 \mathrm{E} 0$ & $8.0 \mathrm{E} 1$ & $2.7 \mathrm{E} 1$ & $\begin{array}{l}\text { - sizing > } f o \text { volume reduction (TT8000) } f b \text { packaging (TT30200) } \\
\text { < sizing > (TT14000) } f b \text { incineration (TT9000) or thermal degradation/volatilization } \\
\text { (TT10000) } f b \text { off-gas treatment (TT23000) } f b \text { vitrification (TT11000) or stabilization } \\
\text { (TT12000) of the 2ash and off-gas residuals. }\end{array}$ \\
\hline $2.0 \mathrm{E} 0$ & $7.5 \mathrm{E} 1$ & $1.9 \mathrm{E} 1$ & not applicable - this is a secondary waste stream \\
\hline $7.8 \mathrm{E} 2$ & $7.8 \mathrm{E} 2$ & $7.8 \mathrm{E} 2$ & not applicable - this waste is no longer generated \\
\hline $2.0 \mathrm{E} 0$ & $2.0 \mathrm{EO}$ & $2.0 \mathrm{EO}$ & 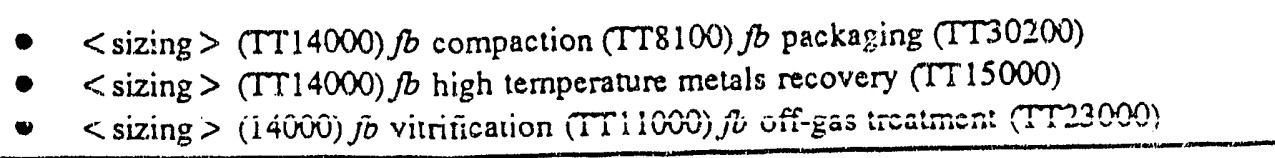 \\
\hline
\end{tabular}


Table 4. (continued).

\begin{tabular}{|c|c|c|c|c|c|}
\hline H & $\begin{array}{l}\text { Waste } \\
\text { Stream } \\
\text { ID }\end{array}$ & Waste stream Deseription & $\begin{array}{l}\text { Annual } \\
\text { Volume } \\
\text { (m3) }\end{array}$ & Current Practice & $\begin{array}{l}\text { Annual } \\
\text { Curies }\end{array}$ \\
\hline 48 & A21 & ABSORBED LIQUIDS, COMBUSTIBLE & 0.4 & $100 \%$ disposal contact & $7.8 \mathrm{E}-6$ \\
\hline $4 !$ & $x 71$ & $\begin{array}{l}\text { ANY COMBINATION OF RESIN } \\
\text { CONTAINERS }\end{array}$ & 0.3 & $100 \%$ disposal-contact & $1.1 \mathrm{E}-2$ \\
\hline 50 & A22 & $\begin{array}{l}\text { ABSORBED LIQUIDS, NONCOMBUSTIBLE- } \\
\text { CEMENT (E.G., PORTLAND CEMENT) }\end{array}$ & 0.1 & $100 \%$ disposal-contact & $2.5 \mathrm{E}-4$ \\
\hline 51 & $\mathrm{M} 23$ & METAL - COPPER & 0.02 & $100 \%$ compaction & $3.2 \mathrm{E}-7$ \\
\hline 52 & $\$ 21$ & SLAG - UNSOLIDIFIED & 0.02 & $100 \%$ disposal-contact & $4.6 \mathrm{E}-5$ \\
\hline 53 & C51 & CORE INSTRUMENTATION & 0.01 & $100 \%$ disposal-contact & 3.4 E-6 \\
\hline 54 & A25 & $\begin{array}{l}\text { ABSORBED LIQUIDS, NONCOMBUSTIBLE- } \\
\text { FULLERS EARTH (E.G. SOIL-DIRT) }\end{array}$ & 0.01 & $100 \%$ disposal-contact & 4.1 E-3 \\
\hline 55 & 583 & SOURCE ALPHA & .001 & $100 \%$ disposal-contact & $7.4 \mathrm{E}-7$ \\
\hline
\end{tabular}




\begin{tabular}{|c|c|c|c|}
\hline $\begin{array}{l}\text { Low } \\
\text { Dose } \\
\text { Rate } \\
\text { (mRhr) }\end{array}$ & $\begin{array}{l}\text { Hoht } \\
\text { Rose } \\
\text { (mRhrir) }\end{array}$ & $\begin{array}{l}\text { Ave, } \\
\text { Dose } \\
\text { Rate } \\
(\mathrm{mR} / \mathrm{hr})\end{array}$ & 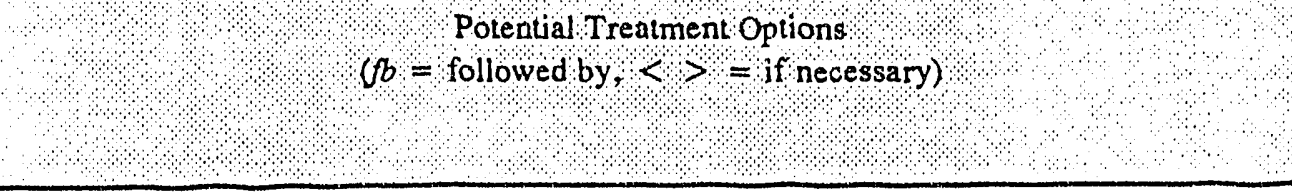 \\
\hline $1.0 \mathrm{E} 0$ & $1.0 \mathrm{EO}$ & $1.0 \mathrm{E} 0$ & $\begin{array}{l}\text { Absorbed Aqueous Liquids: } \\
\text { incineration (TT9000) or thermal degradation/volatilization (TT10000) } f b \text { off-gas } \\
\text { treatment (TT23000) } f b \text { vitrification (TT11000) or stabilization (TT12000) of the ash } \\
\text { and off-gas residuals. } \\
\text { - stabilization (TT12000) } \\
\text { drying (TT6350) } f b \text { stabilization (TT12000) } \\
\text { Absorbed Organic Liquids: } \\
\text { incineration (TT9000) or thermal degradation/volatilization (TT10000) } f b \text { off-gas } \\
\text { treatment (TT23000) } f b \text { stabilization (TT12000) of the ash and off-gas residuals. } \\
\text { drying (TT6350) } f b \text { stabilization (TT12000) }\end{array}$ \\
\hline $1.0 \mathrm{E} 0$ & $6.0 \mathrm{E} 1$ & $2.5 \mathrm{E} 1$ & - shredding (TT83000) fb compaction (TT8100) $f b$ packaging (TT30200) \\
\hline $7.0 \mathrm{E} 1$ & $7.0 \mathrm{E} 1$ & $7.0 \mathrm{E} 1$ & $\begin{array}{l}\text { - } \quad \text { stabilization (TT 12000) fb packaging (TT30200) } \\
\text { package (TT30200) }\end{array}$ \\
\hline $3.5 \mathrm{E} 1$ & $3.5 \mathrm{E} 1$ & $3.5 \mathrm{E} 1$ & $\begin{array}{l}\text { - } \quad \text { sizing > (TT14000) } f b \text { compaction (Tr8100) } f b \text { packaging (TT30200) } \\
\text { - <sizing > (TT14000) } f b \text { high temperature metals recovery (TT15000) } \\
\text { - } \quad \text { sizing > (14000) } f b \text { vitrification (TT11000) } f b \text { off-gas treatment (TT23000) }\end{array}$ \\
\hline $1.0 \mathrm{E} 0$ & $1.0 \mathrm{E} 0$ & $1.0 \mathrm{E} 0$ & $\begin{array}{l}\text { - package (TT30200) } \\
\text { vitrification (TT11000) or stabilization (TT12000)fb <off-gas treatment > (TT23000) } \\
f b \text { packaging (TT30200) }\end{array}$ \\
\hline $2.0 \mathrm{E} 0$ & $2.0 \mathrm{E} 0$ & $2.0 \mathrm{EO}$ & $\begin{array}{l}\text { - } \quad<\text { sizing }>(T T 14000) f b \text { packaging (TT30200) } \\
\text { - } \quad \text { sizing }>\text { (TT 14000) fb compaction (TT8100) fb packaging (TT30200) }\end{array}$ \\
\hline $4.0 \mathrm{E} 1$ & $4.0 \mathrm{E} 1$ & 4.1) E 1 & $\begin{array}{l}\text { - package (TT30200) } \\
\text { vitrification (TT11000) fb off-gas treatment (TT23000) or stabilization (TT12000) }\end{array}$ \\
\hline $1.0 \mathrm{E} 0$ & $1.0 \mathrm{E0}$ & $1.0 \mathrm{EO}$ & insufficient characterization data to identify potential treatments. \\
\hline
\end{tabular}




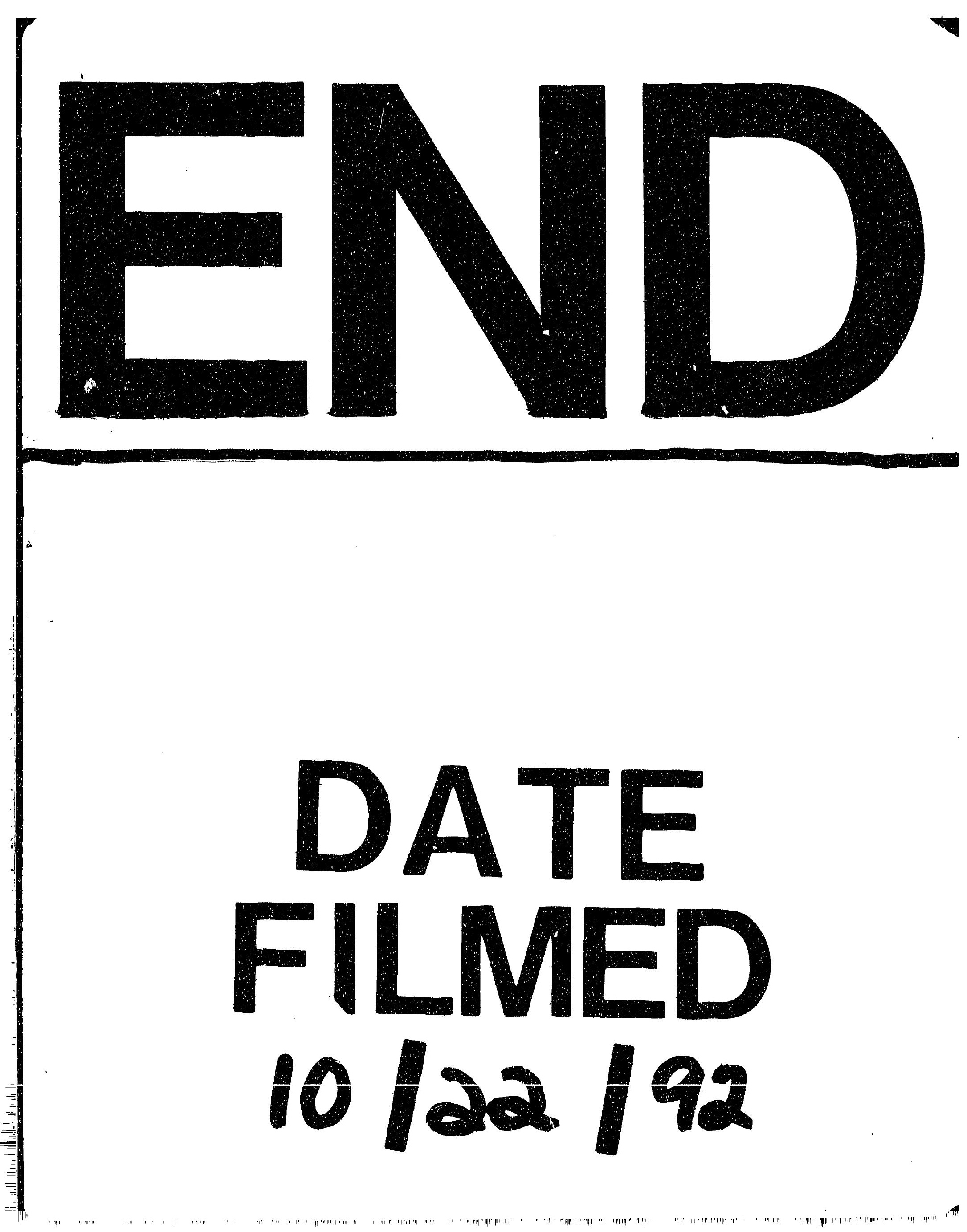


